DOE/ID/12010-4

\title{
INDUSTRIAL APPLICATION OF GEOTHERMAL ENERGY \\ IN SOUTHEAST IDAHO
}

\author{
by
}

James A. Batdorf

David W. McClain

Mark Gross

George M. Simmons

\section{$\checkmark$ IDAHO OFFICE OF. ENERGY \\ OFFICE OF THE GOVERNOR}

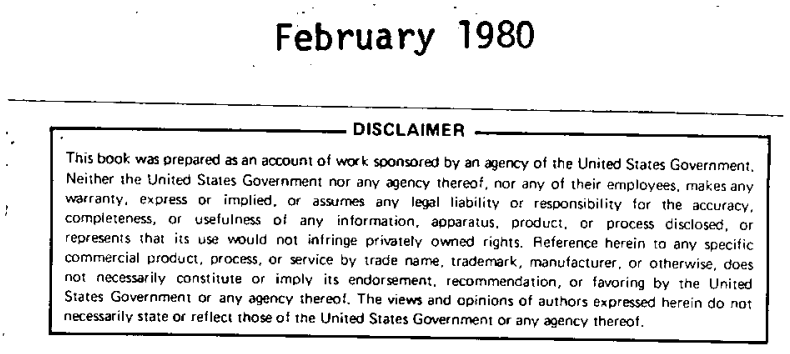

Prepared for the United States Department of Energy, Division of Geothermal Energy, Idaho Falls Operations Office Under Contract No. DE-FC07-79ID12010 


\section{DISCLAIMER}

This report was prepared as an account of work sponsored by an agency of the United States Government. Neither the United States Government nor any agency Thereof, nor any of their employees, makes any warranty, express or implied, or assumes any legal liability or responsibility for the accuracy, completeness, or usefulness of any information, apparatus, product, or process disclosed, or represents that its use would not infringe privately owned rights. Reference herein to any specific commercial product, process, or service by trade name, trademark, manufacturer, or otherwise does not necessarily constitute or imply its endorsement, recommendation, or favoring by the United States Government or any agency thereof. The views and opinions of authors expressed herein do not necessarily state or reflect those of the United States Government or any agency thereof. 


\section{DISCLAIMER}

Portions of this document may be illegible in electronic image products. Images are produced from the best available original document. 
TABLE OF CONTENTS

Page

I. SUMMARY . . . . . . . . . . . . . . . . . . 1

II. INTRODUCTION •. . . . . . . . • . . . . . . 2

III. PHOSPHATE INDUSTRY . . . . . . . . . . . . . . 3

A. Elemental Phosphorus : . . . . . . . . 3

B. Phosphate Fertilizers . . . . . . . . . 8

C. Phosphate Mining . . . . . . . . . . . . 14

IV. FOOD PROCESSING . . . . . . . . . . . . . . 20

A. Typical Potato processing Plant . . . . . . 21

B. Lamb-Weston Example . . . . . . . . . . 27

C. Summary of Remaining Potato Processing Plants . 27

V. ENERGY EXPLORATION IN SOUTHEAST IDAHO • • • • • • . 32

Known Geothermal Resource Prospects . . . . . . 32

Leasing Activity . . . . . . . . . . . 35

Conclusions . . . . . . . . . . . . . . . 36

VI. MAP APPENDIX . ...... . . . . . Attachment 


\section{LIST OF FIGURES}

Page

FIGURE 1: Process Flow Diagram for FMC, Pocatello $\ldots \cdot \ldots \cdot \ldots$ FIGURE 2: Potential Energy Supplied by Geothermal at FMC . . . . . 6 FIGURE 3: Process Flow Diagram for Monsanto Chemical, Soda Springs. . . 7 FIGURE 4: Potential Energy Supplied by Geothermal at Monsanto . . . . 8 FIGURE 5: Process Flow Diagram for Beker Industries . . . . . . . 10 FIGURE 6: Potential Energy Supplied by Geothermal at Beker . . . . . Il FIGURE 7: Process Flow Diagram for J. R. Simplot ........ . i3 FIGURE 8: Potential Energy Supplied by Geothermal at J. R. Simpiot . . 15 FIGURE 9: Process Flow Diagram for Conda Mine. . . . . . . . . 19 FIGURE 10: Potato Processing Flow Diangrams . . . . . . 22 FIGURE 11: Potential Energy Supplied by Geothermal in the Frozen Process 24 FIGURE 12: Potential Energy Supplied by Geothermal in the Flake Process 25 FIGURE 13: Potential Energy Supplied by Geothermal in the Granule Process 26 FIGURE 14: General Flow: Diagram for Lamb - Weston . . . . . . 28 FIGURE 15: Potential Energy Supplied by Geothermal at Lamb - Weston . . 30 FIGURE 16: Total Energy Used for the Potato Processing Industry. . . . . 31 


\section{LIST OF TABLES}

Table 1: Total Energy Requirements for "Typical" Potate Processes....................23

Table 2: Potate Processing Plants in

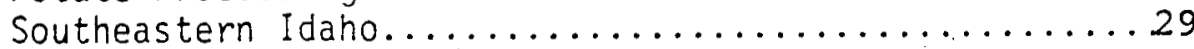

Table 3: High Temperature Geothermal Prospects in Southeast Idaho.

Table 4: Geothermal Well Permits

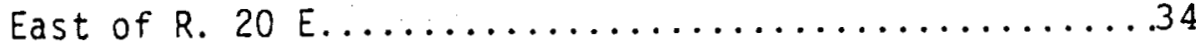

Table 5: State Geothermal Leases

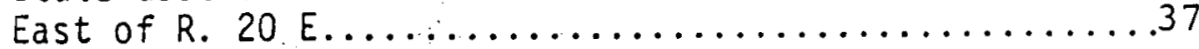

Table 6: Federal Geothermal Leases

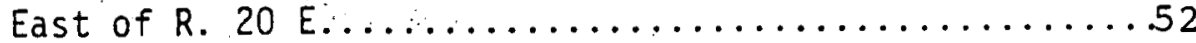

Table 7: State $0 i 1$ and Gas Lease Acreage by Lessee East of R. 20 E....................55

Table 8: Federal 0 il and Gas Lease Acreage

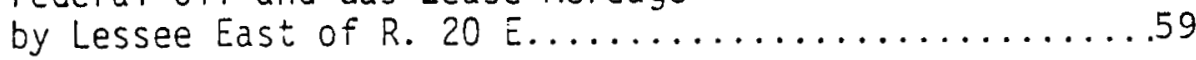

Table 9: 0 il and Gas Exploration Wells in Eastern Idaho (East of R. 20 E.)..............63

Table 10: Idaho State Phosphate Leases

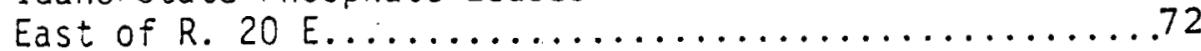

Table 11: Federal Phosphate Leases

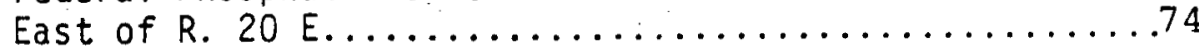




\section{SUMMARY}

Southeastern Idaho has been identified as a region which is geologically favorable to the occurrence of geothermal energy. This area also contains industries which use large amounts of energy in the form of electricity and natural gas. Direct application of geothermal energy can potentially supply some of this energy.

The main industries in Southeastern Idaho are phosphorus/ phosphate production and potato processing. Most of the energy required in the phosphate industries is electrical and therefore not replaceable by direct application of geothermal energy. The main area for direct use of geothermal energy in the phosphate industry is for drying of the ore at the mine site; however, most of this is energy now supplied by waste heat from the calcining process. With these facts in mind there is no reason for further study in the direct application of geothermal energy to the phosphate industry. However, there exists a large need for a dedicated supply of electrical energy to these industries and the possibility of using geothermal energy to generate electricity for these areas should be investigated.

The potato processing industry uses most of its energy to provide process steam for drying and cooking. Geothermal energy can potentially replace most of these energy requirements provided a high enough source temperature can be located: A $200^{\circ} \mathrm{F}$ geothermal source could supply about 40 o of the industry's needs or about $2.6\left(10^{12}\right) \mathrm{BTU} / \mathrm{yr}$. A $400^{\circ} \mathrm{F}$ geothermal source could supply nearly $90 \%$ of the industry's needs or about 5.8 (1012) BTU/Yr.

Southeastern Idaho is an area endowed with certain geological characteristics which favor the occurrence of geothermal energy. There is a reasonable probability that exploration wells drilled anywhere within this region will encounter temperatures as high as $2000 \mathrm{~F}$ at depths as shallow as 3,000 feet. Temperatures as high as $400^{\circ} \mathrm{F}$ have been proven through deep exploration drilling (10,000 feet) in the snake River Plain and in the Sray's Lake area. Five sites in Southeastern Idaho are considered to be potential high temperature geothermal resource exploration areas. These sites are Battle Creek Hot Springs, Franklin County; Big Creek Hot Springs, Lemhi County; Blackfoot Reservoir, Caribou County; Magic Reservoir, Blaine County; and Raft River, Cassia county. Geochemical water analysis at these five sites indicates subsurface reservoir temperatures in excess of $300^{\circ} \mathrm{F}$ may exist. Exploration drilling is needed to prove the existence of a usable resource at these sites.

Geothermal resource temperatures sufficient for food processing ( 200 to $\left.300^{\circ} \mathrm{F}\right)$ are probable within the snake River Plain of 
Southeastern Idaho at depths between 5,000 and 10,000 feet. Exploration for geothermal resources in the Snake River Plain can be considered to be very high risk due to lack of geological data regarding porosity, permeability and general hydrology.

Exploration for oil and gas in the Overthrust Belt of Southeastern Idaho has encountered high temperatures at depths of 5,000 to 10,000 feet. Further exploration in this region for oil and gas may prove existence of a geothermal resource capable of electrical generation or industrial processing.

\section{INTRODUCTION}

The Snake River Plain in Southern. Idaho contains a large and identified geothermal resource. Most of these resources are at temperatures of less than $200^{\circ} \mathrm{F}$; however, some locations contain resources up to $300^{\circ} \mathrm{F}$. There are undocumented indications that sources up to $500^{\circ} \mathrm{F}$ have been located.

Throughout the same area there is also a concentration of industry requiring large energy inputs. These industries are composed almost entirely of the phsophorus/phosphate industries and the potato processing industry. This report identifies those phosphate related and food processing industries in Southeastern Idaho which require large energy inputs and assesses the potential for direct application of geothermal energy. The total energy demand is given along with that fractional demand that can be satisfied by a geothermal source of known temperature.

The report will discuss the specific industries in the following order:

A. Phosphorus Industry

1. Elemental Phosphorus

a. FMC-Pocatello

b. Monsanto-Soda Springs

2. Phosphate Fertilizer

a. J.R. Simplot-Pocatello

b. Baker Industries-Conda

3. Phosphate Mining

a. Simplot

b. Beker

c. Monsanto

d. Other

B. Potato Processing

1. General Process Description

a. Granule Production

b. Potato Flake Process

c. French Fry (frozen) 


\title{
2. Base Case Potato Plant
}

\section{Compilation of Potato Processing Plants}

The potato plants will be compared to a "typical" potato processing plant. The energy reguirements section will identify the percentage of a particular plant's energy needs which could be replaced by direct utilization of geothermal energy. This percentage depends on the available temperature of the geothermal resource. Each plant will be examined using the format shown below.

\author{
Process Description \\ General Flow Diagram \\ Energy Requirements \\ Present Energy Usage \\ Electrical \\ Natural Gas \\ Comments on Geothermal Potential
}

The report will analyze the potential for geothermal resource development by examining the location of known thermal springs and wells, the location of state and federal geothermal exploration leases, and the location of federal and state oil and gas leasing activity in Southeast Idaho. Information is also presented regarding the location of geothermal, oil, and gas exploration wells in Southeast Idaho. The location of state and federal ohosphate mining leases is also presented. This information is presented in table and map formats (see Appendix) to show the proximity of exploration and development activities to current food and phosphate processing facilities and phosphate mining activities.

\section{PHOSPHATE INDUSTRY}

\section{A. Elemental Phosphorus Production}

The two producers of elemental phosphate in southern Idaho are FMC Corporation and Monsanto Chemical. FMC is located outside of Pocatello, Idaho, and produces 120,000 tons of phosphorus per year, requiring about 1.1 million tons of phosphate ore. The plant's electrical demand is about 210 liw. Monsanto Chemical is located at Soda Springs, Idaho, and produces 100,000 tons of phosphorus per year from about 700,000 tons of phosphate ore. Monsanto's electrical demand is about $140 \mathrm{Mw}$. 


\section{FMC Corporation-Pocatello, Idaho}

Process Description. The plant receives phosphate ore with a moisture content of approximately 11\%. This ore is screened, crushed, and briquetted. The vater in the ore aids in the briquetting process and therefore this ore could not be pre-dried. The briquets are calcined in natural gas/carbon monoxide calciner. The calcined briquets are mixed with silica and coke and fed to any of four electric furnaces. By-products from the furnace consist of ferrophos and slag. The overhead gases from the furnace pass through a precipitator and then to spray condensers where the phosphorus is recovered. The dust from the precipitators is slurried with water and then dried in a natural gas fired fluidized bed unit. The co off gas from the condensers is recycled back and used as a combustion gas in the calciner. This process is shown in Figure 1 .

Energy Requirements. The energy required for this process is provided by natural gas and electricity. Locations of energy use which can feasibly be substituted by geothermal include steam oroduction at $400^{\circ} \mathrm{F}$ and drying of product recovered from the precipitator. These energy requirements and their associated temperatures are shown in Figure 2 .

Geothermal Potential at FMC. This industry has two main locations of energy consumption: electric furnaces and calciners. The electric furnaces use $90 \%$ of the energy required by FMC. The plant has an excess of carbon monoxide from the electric arc furnaces which it plans to recover and use to reduce natural gas consumption. This waste energy is about 219 (109) BTU/Yr. or $30 \%$ of their natural gas requirements. The potential use of geothermal energy is in the generation of process steam and fluid bed dryer which are also the most likely places for use of waste heat. If this energy is used in the boiler and fluid bed dryer there will be reduced potential for geothermal energy. The large electrical requirements of this plant are presently on interrupt power and suggest a need for a dedicated electrical supply which could possibly be supplied by a geothermal power cycle. 


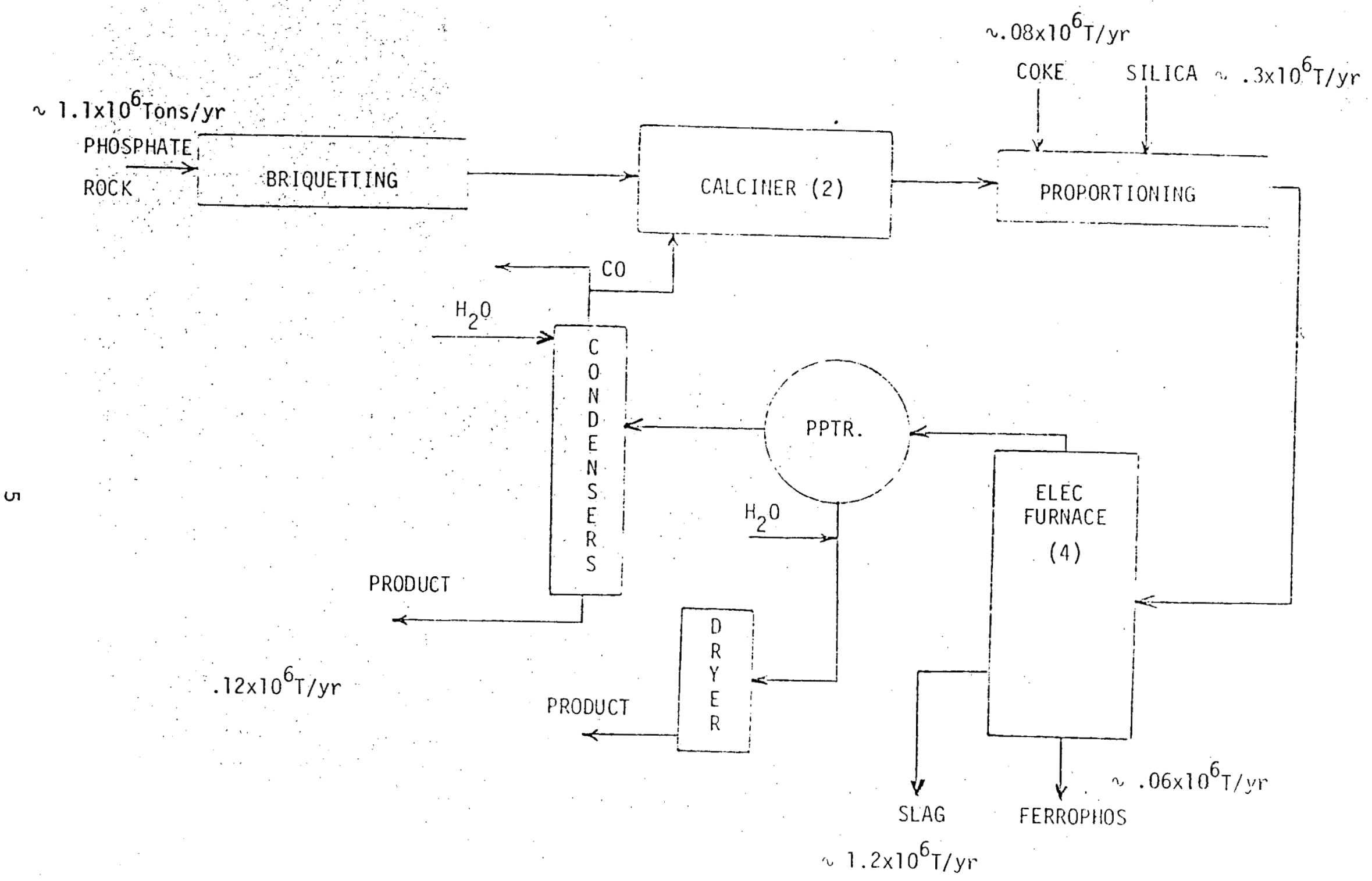

FIGURE 1. PROCESS FLOW DIAGRAM FOR FMC, POCATELLO 
FIGURE 2: POTENTIAL ENERGY SUPPLIED BY GEOTHERMAL

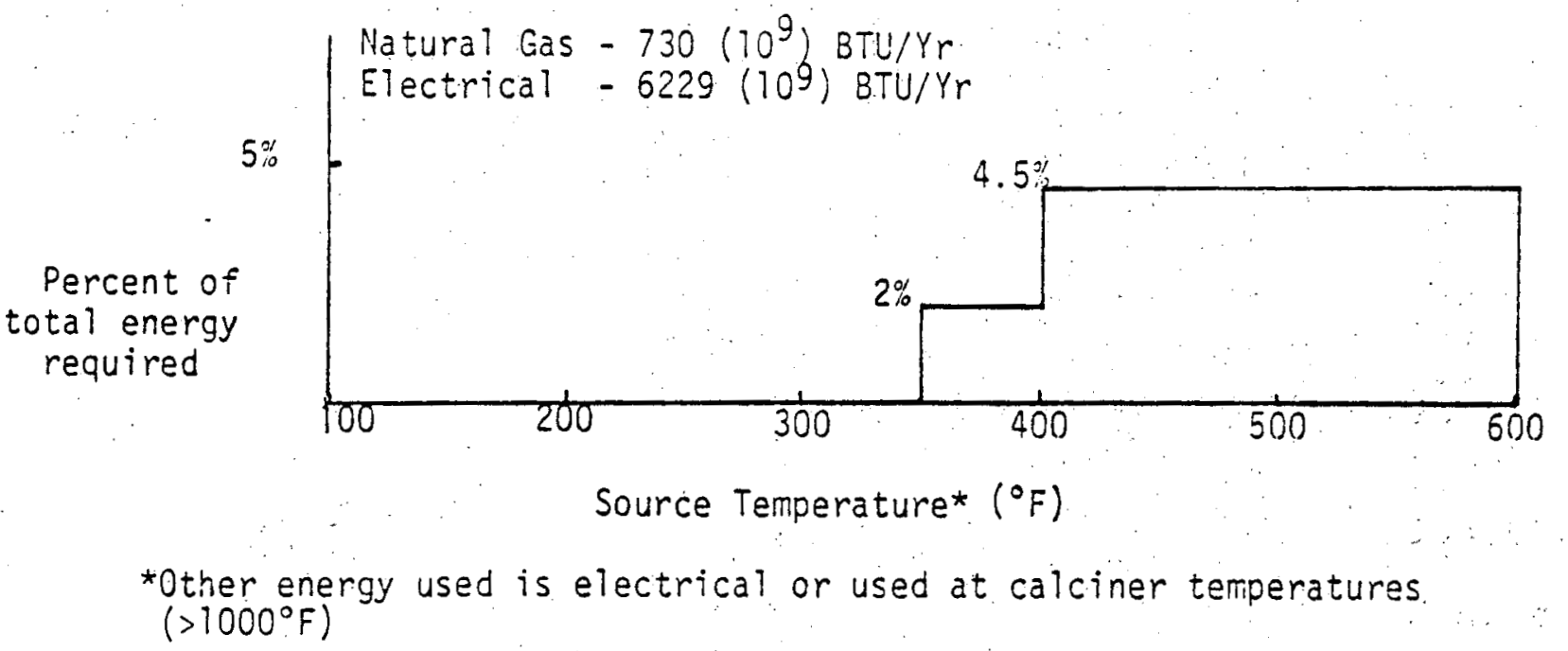

2. Monsanto Chemical-Soda Springs

Process Description. Phosphate ore is crushed and screened and then fed to a large rotary kiln where it is "nodulized." This process dries the ore and removes the organic materials as well as calcining the ore. The calcined ore is combined with coke and quartzite and fed to one of three electric furnaces. The off-gases from the furnaces contain the elemental phosphorus product and are fed to a condenser where they are contacted directly with water from a closed cycle "phossy water" system. The carbon monoxide gas from the condenser is recycled as fuel for the kiln. The solids products from the furnace include a waste slag stream and "ferrophos" alloy. The process and approximate flow rates are shown in Figure 3 .

Energy Requirements. The major energy required for this process includes electricity to operate the electric arc furnaces and natural gas to supplement the rotary kiln and to operate a small steam boiler. A waste heat boiler operating off the kiln off-gas provides a substantial amount of the process steam requirements. The natural gas used for process steam generation accounts for about $5 \%$ of the total energy required at Monsanto and is potentially replacable by geothermal energy. This would require a geothermal source of at least $400^{\circ} \mathrm{F}$ (Figure 4). 


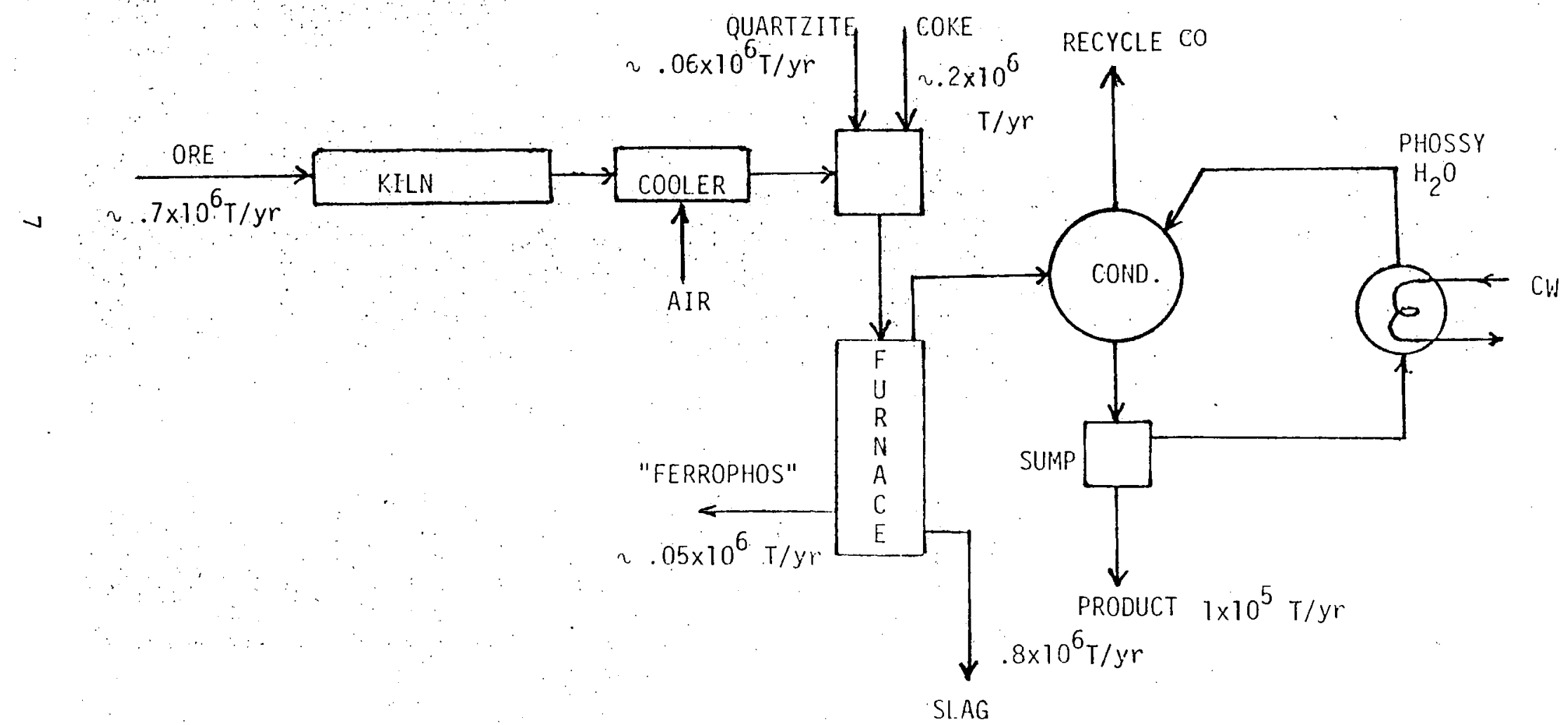

FIGURE 3: PROCESS FLOW DIAGRAM FOR MONSANTO CHEMICAL, SODA SPRINGS 
FIGURE 4:. POTENTIAL ENERGY SUPPLIED BY GEOTHERMAL

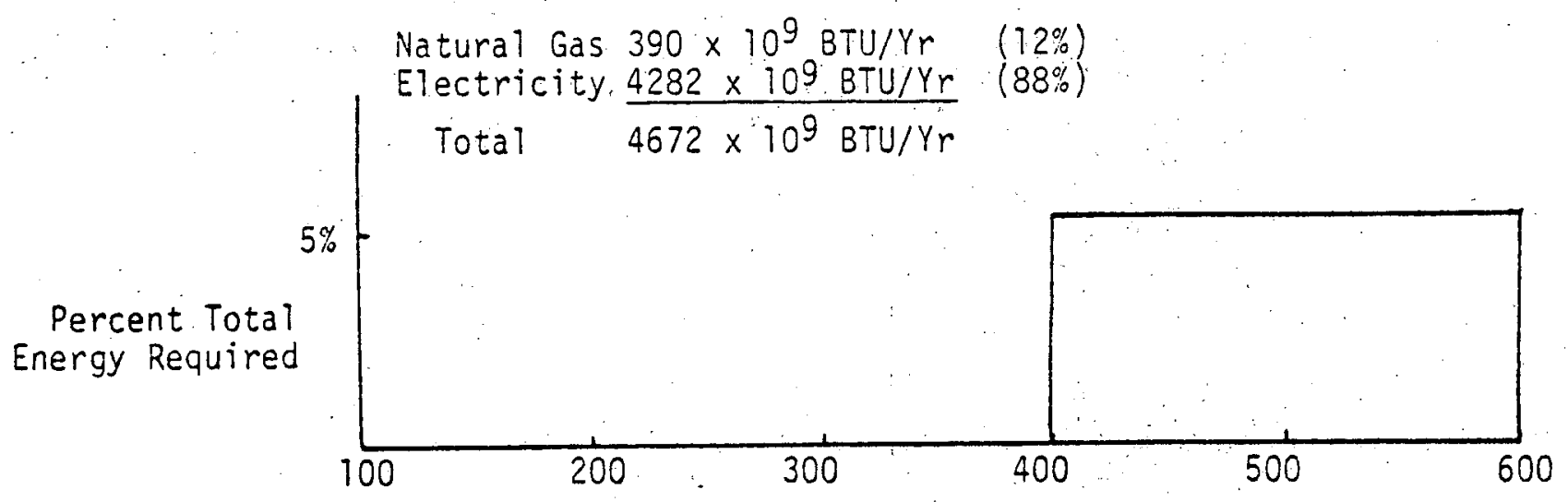

Energy Source Temperature* $\left({ }^{\circ} \mathrm{F}\right)$

* Remaining requirements are electrical or used at temperatures exceeding $1000^{\circ} \mathrm{F}$.

Geothermal Potential at Monsanto. Most of the

- energy used at Monsanto that could be replaced by a geothermal supply is presently being supplied by a waste heat boiler operating on the kiln off-gas stream. The natural gas used is primarily for start-up of the kiln and not replaceable by direct application of geothermal energy. The plant's large electrical requirements ( $140 \mathrm{Mw}$ ) suggest the need for a dedicated energy supply instead of the present interruptible power supply. A geothermal power cycle might be able to supply this energy, but would require well in excess of $25,000 \mathrm{gpm}$ of $300-400^{\circ} \mathrm{F}$ water.

B. Phosphate Fertilizer Industry

The two companies producing phosphate fertilizers in Southern Idaho are Beker Industries and J.R. Simplot Company.

Beker is located in Conda, Idaho and produces 665 tons per year of fertilizer in the form of monoammonium phosphate (MAP), diammonium phosphate (DAP), and phosphoric acid at either $52 \%$ or $72 \% \mathrm{P}_{2} \mathrm{O}_{5}$ concentration. This year (1979). production has been limited to $528 \mathrm{P}_{2} \mathrm{O}_{5}$ due to a high magnesium content in the ore. This production requires about 1.5 miliion tons of phosphate ore which is mined near Conda. The plant's overall energy 
requirements are met mainly by waste heat from the production of sulfuric acid from elemental sulfur. Purchased electricity is on the order of 5-10 Mw.

J.R. Simplot Company is located outside of Pocatello, Idaho, and produces about 1.0 million tons of fertilizer products annually. The phospinate products consist of ammonioum phosphate (365,000 T/Yr.), triple super phosphate (73,000 T/Yr:), phosphoric acid (292,000 T/Yr.), and super phosphoric acid $(183,000 \mathrm{~T} / \mathrm{yr}$.$) . Other$ Products include ammonium sulfate $(64,000 \mathrm{~T} / \mathrm{Yr}$.$) and$ a nitrogen solution, UN-32 (64,000 T/Yr.). Simplot's energy requirements include about $20 \mathrm{MW}$ of electricity and some natural gas for steam production. Simplot also produces sulfuric acid and recovers the waste heat for steam production.

\section{Beker Industries-Conda, Idaho}

Process Description. Beker's production plant is divided into two main sections, the mining operations and the phosphoric acid plant (Figure 5).

Mining Operations. The plant receives nearly 3.0 million tons of phosphate ore per year from Beker's mines near Conda for beneficiation and calcination. The ore is washed to remove some of the organics and fines and then filtered to about $14 \%$ moisture content. One-half of this ore is dried and then mixed with the wet ore to provide a calcine feed with 6-7\% moisture. The ore has a high BTU content and is nearly self-calcining. Natural gas use is less than $22.0 \mathrm{million}$ BTU/Yr. Waste heat from the calcination is recycled to accomplish the drying. The mining operations produces an average of 500 ? ton per day of calcined ore. About 50\% of this ore is shipped by rail to Calgary, Canada. The other half is used by phosphoric acid plants.

Phosphoric Acid Plant. The phosphoric acid plant consists of three sections. One section burns sulfur to product $\mathrm{SO}_{2}$ for the production of sulfuric acid. The next section mixes the sulfuric acid with calcined phosphate rock to produce phosphoric acid. Ten-fifteen percent of this acid is then concentrated in steam operated evaporators to produce either $52 \%$ or $70 \%$ phosphoric acid $\left(\right.$ as $\left.\mathrm{P}_{2} \mathrm{O}_{5}\right)$. The remaining acid is combined with sulfuric acid, ammonia and calcined phosphate to produce either monoammonium phosphate (MAP) or diammonium phosphate (DAP). The product is granulated by a mechanical operation and dried to produce granular MAP and DAP. 


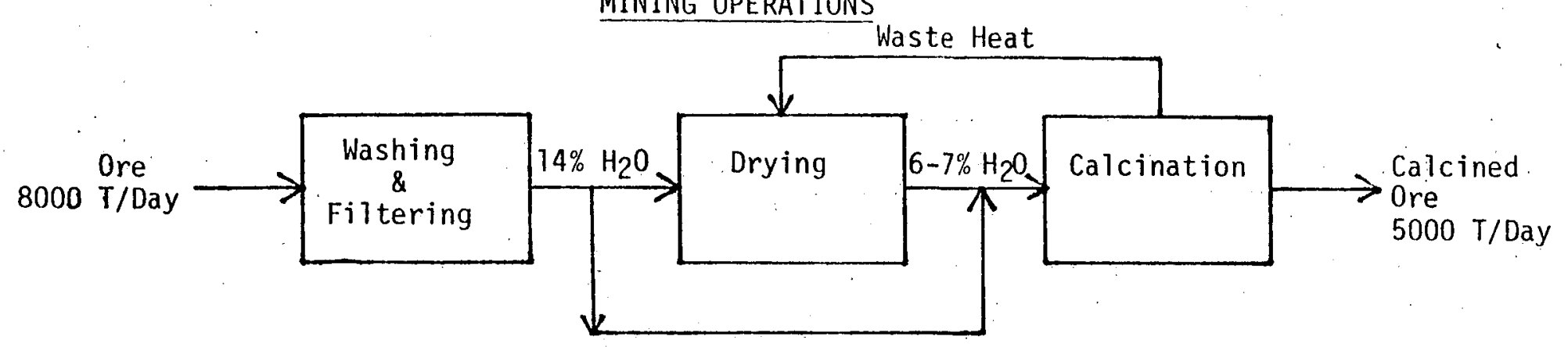

ம

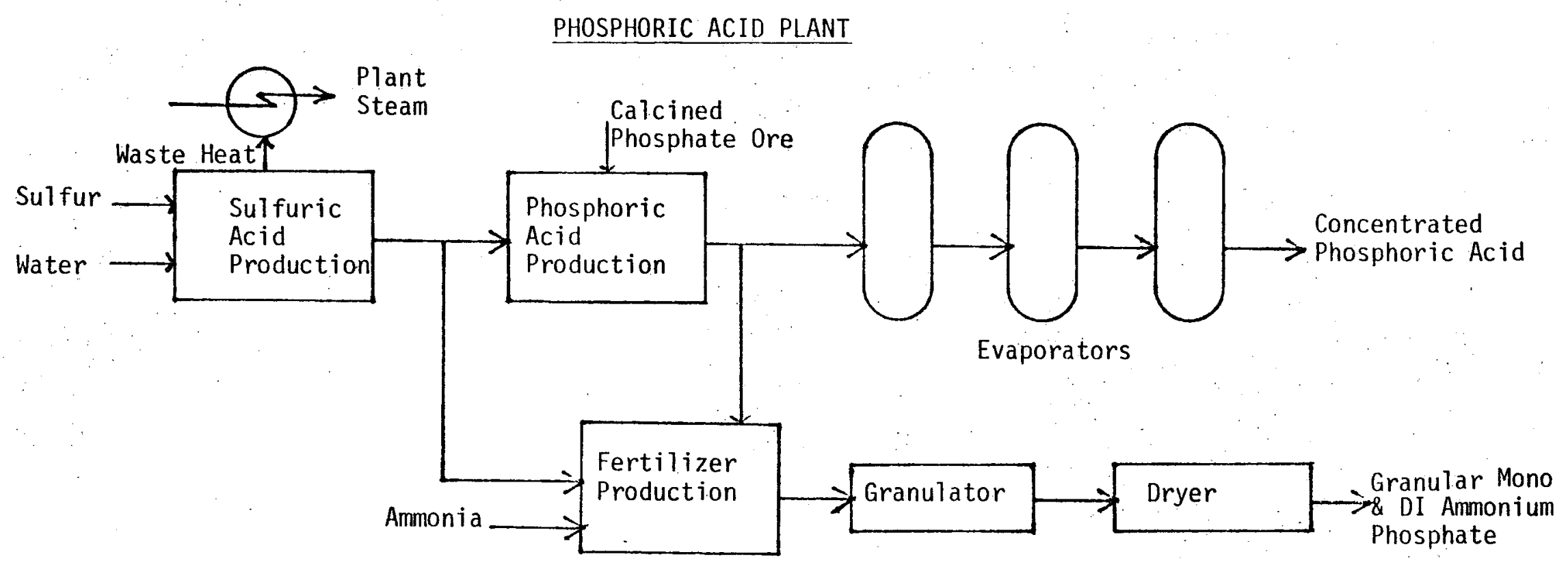

FIGURE 5: PROCESS FLOW DIAGRAM FOR BEKER INDUSTRIES 
Energy Reguirements. The major energy requirements at Beker are met by electricity and waste heat from the production of sulfuric acid. Some natural gas is used in the calcination process and for supplemental steam. Geothermal energy could be used for process steam generation instead of natural gas. This would require a geothermal source of at least $400^{\circ} \mathrm{F}$ and could potentially replace $1 \%$ of Beker's energy requirements (Figure 6 ).

FIGURE 6: POTENTIAL ENERGY SUPPLIED BY GEOTHERMAL AT BEKER

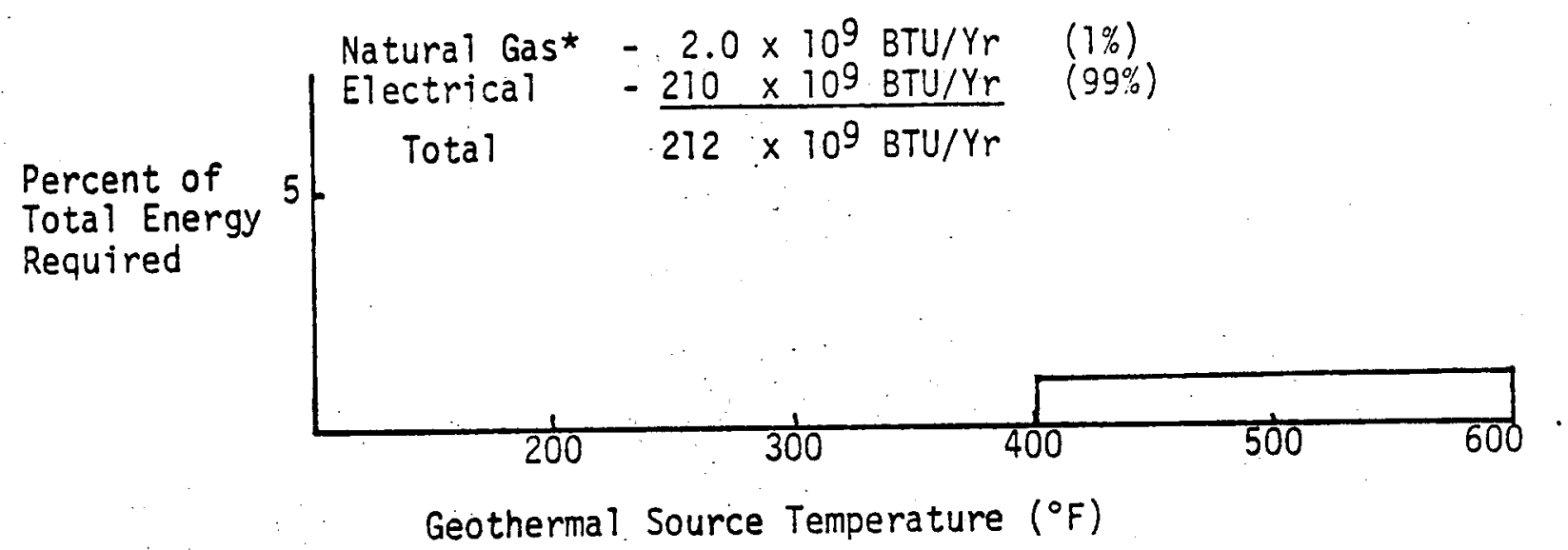

*This assumes that Beker's natural gas requirements are proportionately similar to Simplot's. 
Geothermal potential at Beker. The plant's nonelectrical requirements are almost entirely met by waste heat. Some natural gas is used but this is primarily for start-up of the calcination process. There does not appear to be a need for direct application of geothermal energy at their location.

2. J.R. Simplot-Pocatelio, Idaho

Process Description. This plant is actually an integrated complex consisting of a number of separate plants. There are three sulfuric acid plants (500, 600 and 1100 tons/day), two ammonia plants (150 tons/day each), two ammonium phosphate plants (1,000 tons/day); an ammonium sulfate plant ( 150 tons/day), a phosphoric acid plant which produces phosphoric acid for other portions of the complex (Triple super Phosphate or TSP, ammonium phosphate) as well as for direct sales and a nitrogen solutions plant (UN-32). (See Figure 7.)

The sulfuric acid plants are standard in that sulfur is burned to produce $\mathrm{SO}_{2}$ which is then converted catalytically to $\mathrm{SO}_{3}$ before absorption in a recycle $\mathrm{H}_{2} \mathrm{SO}_{4}$ stream.

The ammonia plants are also standard and employ natural gas as a feed stock. The natural gas is steam: reformed in the presence of a catalyst and tinen, after shift conversion, $\mathrm{CO}_{2}$ absorption and methanation, it is catalytically combined with nitrogen to form ammonia. A portion of the ammonia is fed to the ammonium phosphate and sulfate plants and the remainder to the nitrogen solutions plant. In this latter plant, some of the ammonia is oxidized to $\mathrm{NO}_{X}$ over a platinum gauge catalyst and then absorbed in water to form nitric acid. Another portion of the ammonia is reacted with stripped $\mathrm{CO}_{2}$ from the ammonia plant to form urea. The nitric acid is neutralized and then mixed with the urea to form a eutectic mixture of urea and ammonium nitrate (UN-32).

The feed to the phosphoric acid plant consists of phosphate rock and sulfuric acid. The rock is first calcined in three fluidized bed calciners and then mixed with $\mathrm{H}_{2} \mathrm{SO}_{4}$. The waste stream from this process is gypsum $\left(\mathrm{CaSO}_{4}\right)^{2}$ which is sent to a disposal pile. The acid is concentrated to various degrees in evaporators for either direct sale or to produce liquid fertilizer and ammonium phosphate.

The remaining plants are basically mixing operations, usually with some drying involved. Thus, TSP is produced by mixing phosphoric acid with phosphate rock and then dried; ammonium phosphate results from the mixing of $\mathrm{NH}_{3}$, 


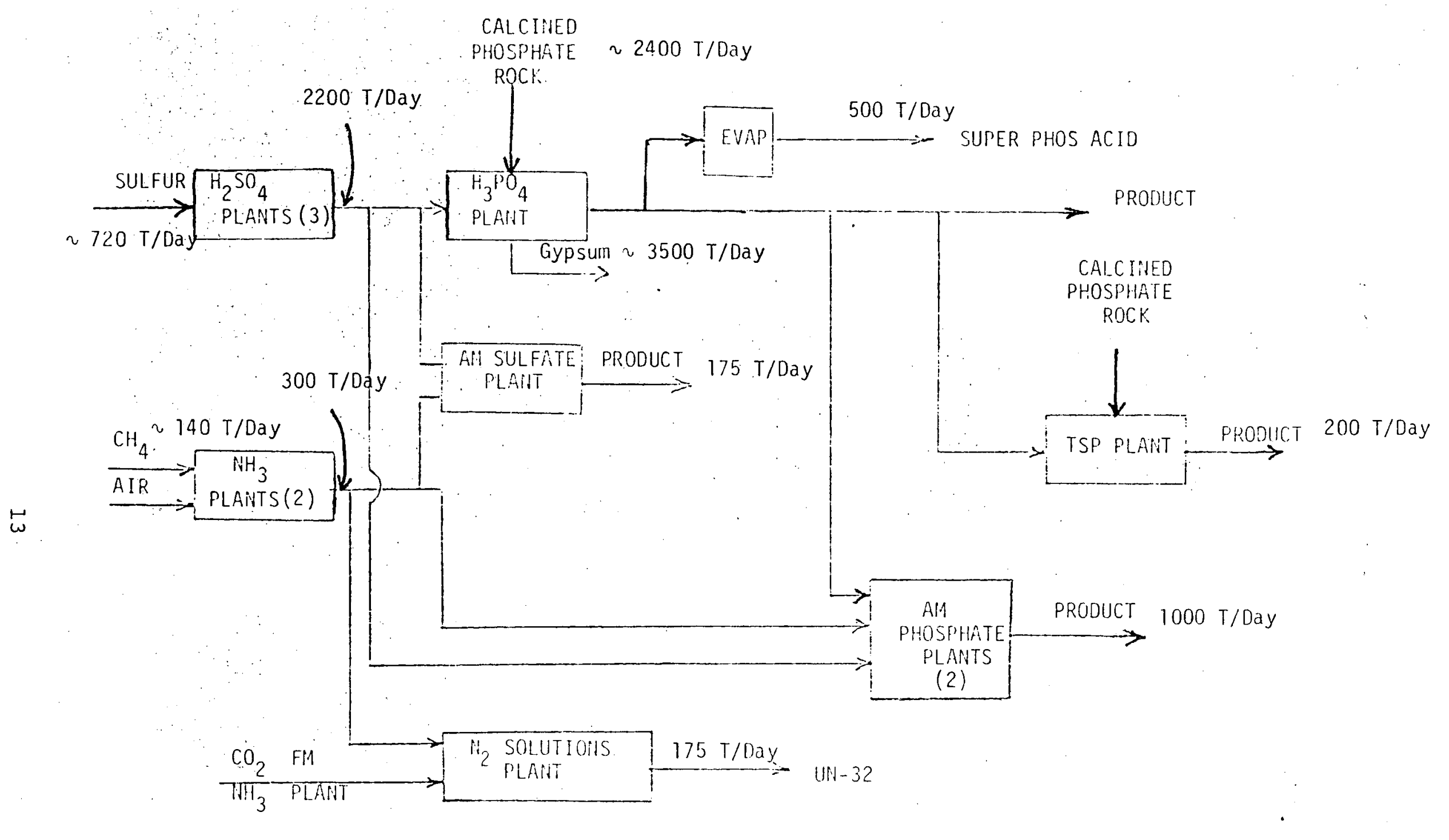

FIGURE 7: PROCESS FLOW DIAGRAM, SIMPLOT 
$\mathrm{H}_{3} \mathrm{PO}_{4}$ and $\mathrm{H}_{2} \mathrm{SO}_{4}$ which is then granulated and dried; ammonium sulfate is crystallized from a mixture of $\mathrm{NH}_{3}$ and $\mathrm{H}_{2} \mathrm{SO}_{4}$ followed by centrifuging and drying.

Energy Requirements. Simplot also acquires large amounts of waste heat from the production of sulfuric acid. The total natural gas used by simplot is high but a large portion of this is used as feedstock to the ammonia plant. Simplot also uses natural gas. to operate three fluidized bed calciners. The energy at Simplot replaceable by geothermal water is primarily that used for steam production (Figure 8).

Geothermal Potential at Simplot. Simplot is similar to Beker in that most of the non-electrical plant energy requirements are supplied by waste heat. There does not appear to be a need for the direct application of geothermal potential.

C. Phosphate Mining

The major phosphate mining operations in southern Idaho are Beker Industries, Monsanto Company, J.R. Simplot, and Stauffer Chemical Company. The Alumet Grouo and Earth Sciences, Inc., also have plans for mining in southern Idaho but are not presently in operation.

Beker Industries strip mines nearly 3.0 million tons of ore per year. Mining and shipping is limited to the non-winter months, generally May to November depending on the weather. Monsanto mines up to $1.0 \mathrm{million}$ tons of ore per year. Stripping is done year round but weather restricts mining and shipping to the months of May through october or November. J.R. Simplot Company operates two mines; both mines are located east of Conda, Idaho. Simplot's Gay mine produces about 3.0 million tons of phosphate ore per year. About 1.5 million tons of this ore is shipped to FMC Corporation, Pocatello and the other half is sent to Simplot's Conda mine for beneficiation. The mine is operated during non-winter months due to weather considerations. The Conda mine operates year round because the ore is dried sufficiently in the beneficiation process to allow shipping.

1. Alumet Group-Diamond Creek, South End of Upper Valley (about 20 miles Northeast of Soda Springs).

Process Description. There is no production at Diamond Creek at the present time. The Alumet Group plans to start mining in the near future at a rate of 0.5 million tons per year. The ore will be transported by truck to the rail spur now serving the Wooley valley mine. 
FIGURE 8: POTENTIAL ENERGY SUPPLIED BY GEOTHERMAL AT SIMPLOT

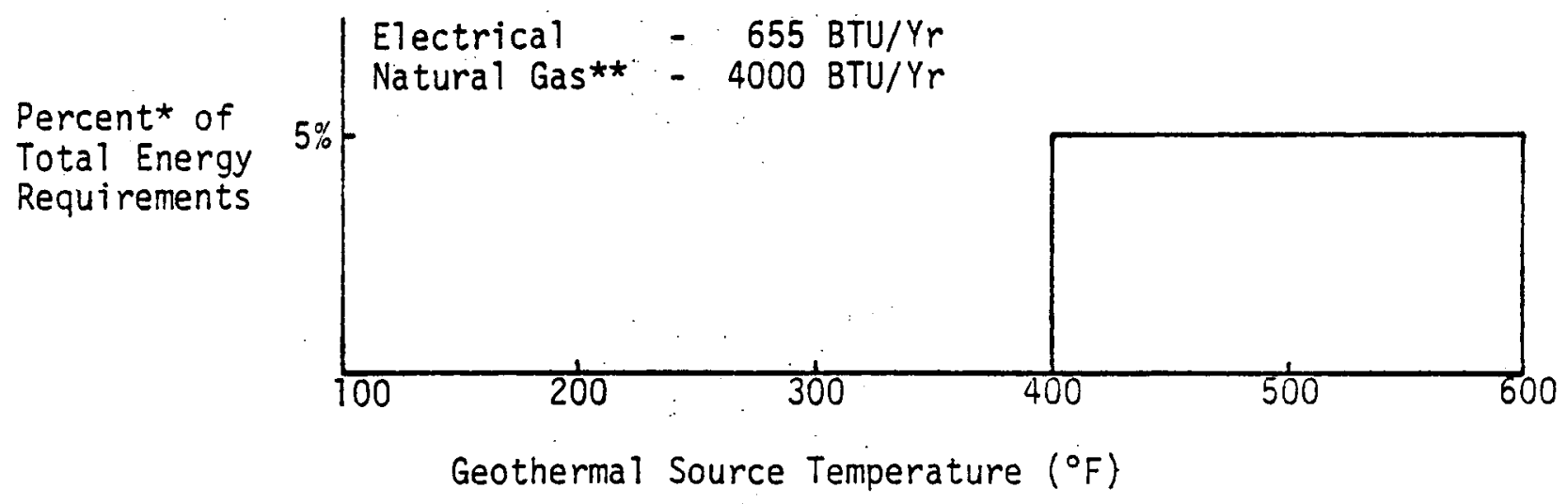

* Does not include natural gas used for armonia production.

**Approximately $2500 \times 10^{9}$ BTU/Yr is used as feedstock to the ammonia plant. 
Process Elow. No onsite processing is anticipated at this time. The ore may be beneficiated at a mill near Diamond Creek in the future. This would be a dry-process beneficiation plant.

Energy Requirements. No process.

Geothermal Potential at Alumet. A dry-process beneficiation involves crushing and screening of the ore and has no use for direct application of geothermal energy.

2. Beker Industries Corporation-North and South Maybe Canyon (about 16 miles Northeast of Soda Springs.

Process Description. Beker Industries presently mines about 2.7 million tons of ore per year. This ore is shipped about 35 miles by rail to the fertilizer plant at Conda, Idaho. At the plant the ore is beneficiated and calcined. The ore is mined and shipped from May to November depending on weather conditions. Snow and ice cause many problems with their mining operations. The ore is stockpiled at the fertilizer plant for winter operation.

Process Flow Diagram. Only mining operations.

Energy Requirements. Since there is no beneficiation at the mine there are no requirements directly compatible to geothermal energy.

Geothermal Potential at Beker Mine. Since the mine is difficult to operate in the winter it is not likely to be desirable to do beneficiation at the mine and this makes it unlikely that there would be a future use for geothermal energy at the mine.

3. Earth Sciences, Inc.-Paris-Bloomington Mine $(2$ miles west of Bloomington, Idaho).

Process Description. There is no production at this time. However, future plans include an underground mine to produce high-grade phosphate ore and a beneficiation plant near the mine site.

Process Flow. No designed process at this time. 
Energy Requirements. No production.

Geothermal Potential at Earth Sciences, Inc. It is unlikely that Earth Sciences will have a use for the direct application of geothermal energy but this depends on the ore properties and specific beneficiation process used.

4. Monsanto Company-Henry Mine

Process Description. Monsanto can strip mine a maximum of 1.0 miliion tons per year of phosphate ore from the Henry. Mine. Stripping is done year round but weather prevents transportation to the plant during the winter months. From May to October or November the ore is shipped by truck to the phosphoric acid plant at soda springs. No beneficiation is provided at the mine.

Process Flow Diagram. Mining operations only.

Energy Requirements. Energy usage is not compatible to a geothermal source.

Geothermal Potential at Monsanto's Mine. Geothermal energy would be advantageous if drying was accomplished at the mine. However, since it is difficult to operate the mining equipment during the winter, a drying operation at the mine would not be sufficient for year round shipping.

5. J.R. Simplot Company-Gay Mine (approximately 2 miles east of Conda, Idaho

Process Description. Simplot mines over 3.0 million tons annually from the Gay mine. Approximately 1.5 million tons of this ore is sold to FMC Corporation in Pocatello for the production of elemental phosphorus. FMC's process requires that the ore have a moisture content of 8-12 percent. Therefore FMC's ore is shipped unbeneficiated. The other 1.5 million tons is shipped to the Simplot Conda mine for beneficiation. 
at Gay mine.

Energy Requirements. Since there is no beneficiation or drying, energy requirements are not compatible to a geothermal source.

Present Energy Usage. The energy used at this time is mainly in the form of diesel fuel for the mining equipment.

Geothermal Potential at the Gay Mine. Since FMC's ore is not dried and simplot beneficiates their ore at the Conda mine it is not likely that a beneficiation or drying process will be considered for this mine and geothermal energy will therefore not be of use.

6. J.R. Simplot-Conda Mine (east of Conda, Idaho)

Process Description. About 1.0 million tons of phosphate ore is mined at this site annually. This ore, along with 1.5 million tons per year from the Gay mine, are beneficiated before being shipped to the fertilizer plant at Pocatello. Beneficiation includes a washing stage which removes the fines and most carbonaceous material. The ore is dried and then calcined. Since the ore is essentially self-calcining very little natural gas is required. Waste heat from the calcination stage is used for the drying stage. The ore is dried more during the winter to reduce freezing problems in shipping. Calcined ore is then shipped by rail to the fertilizer plant at Pocatello (Figure 9).

Energy Requirements. Present energy requirements at simplot are met by electricity and waste heat from the calcination process. The only potential use of direct geothermal application is that energy now met by waste heat.

Geothermal Potential at Simplot. If an alternate heat source were available the ore could be dried at the mine but not calcined until it reached the plant which would provide more waste heat at the plant. To replace this calcine waste heat with geothermal water would take about $29,000 \mathrm{gpm}$ at $300^{\circ} \mathrm{F}$. This assumes a $100^{\circ} \mathrm{F}$ drop in geothermal temperature and $60 \%$ efficiency. The conclusion is that any use for geothermal at either the mining or the plant site would only replace existing waste energy. we see no ultimate use for direct appiication of geothermal energy. 


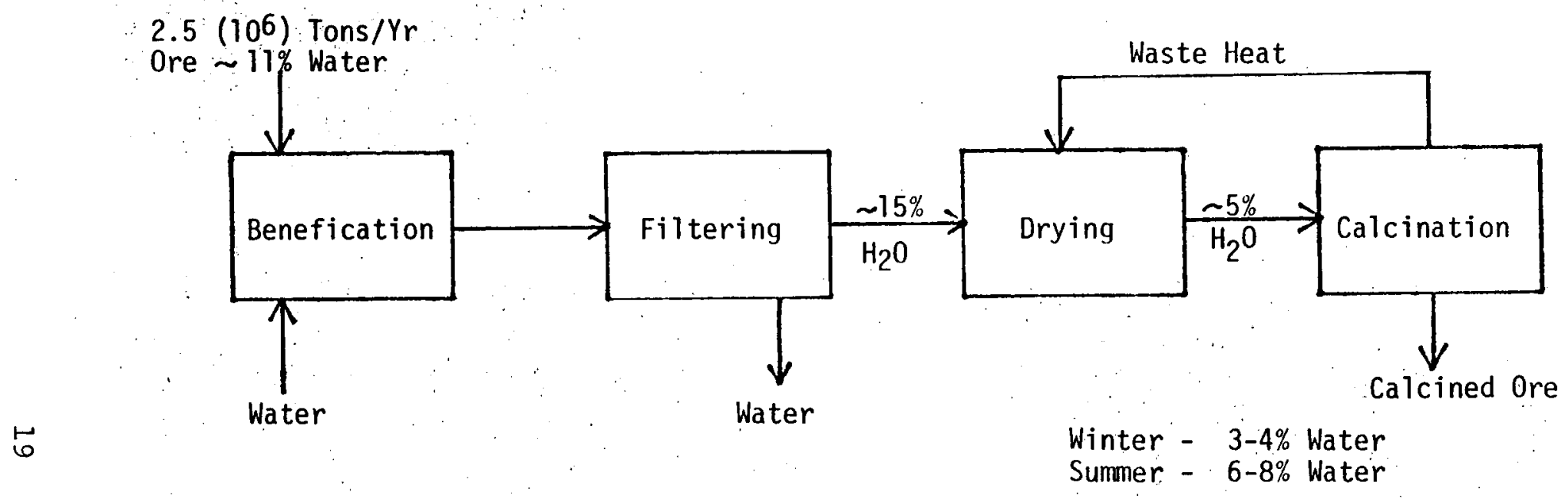

FIGURE 9: PROCESS FLOW DIAGRAM FOR CONDA MINE 
7. Stauffer Chemical Company-Wooley Valley Mine

Process Description. Stauffer presently mines $1.0 \mathrm{million}$ tons of ore per year. Stripping and ore extraction is done with rubber-tired scrapers, assisted by crawler dozers in loading. Stripping is done year round. The ore is hauled to a stockpile and loaded on railroad cars during the non-winter months, generally June to October. The ore's 10-12 percent water content makes shipping in the winter months impossible. The unbeneficiated ore is shipped by rail to Silver Bow, Montana, and Leefe, wyoming.

Process Flow Diagram. There is no beneficiation or arying process at this time.

Energy Requirements. The energy required is in the form of fuel for the mining equipment and not compatible to a geothermal resource.

Geothermal Potential at stauffer. If a beneficiation or drying process were to be used it would probably change the shipping duration. Stauffer will not do beneficiation unless an incentive such as transportation difficulties or inexpensive energy supply is encountered.

8. Summary of Phosphate Mining

It appears that the only potential use for geothermal energy is in the drying operation at the mine. This drying might allow the mine to operate during the winter months; however, there are many other winter-related problems not alleviated by drying the ore. Those operations that do drying also do beneficiation (which includes calcining the ore). In most cases the waste heat from beneficiation is sufficient to accomplish drying. There does not appear to be a role for direct application of geothermal in the phosphate industry.

\section{FOOD PROCESSING}

The major food processing industries in southeastern Idaho are potato processing plants. These plants have similar processes and similar energy requirements. The potential use of geothermal energy in these plants "will be examined by defining a "typical" potato processing plant. This plant will show the general energy requirements of a potato plant. Lamb-Weston's processing plant in American Falls will be compared to this "typical" plant as an example. Total energy requirements of the remaining plants will be given. 
A. Typical Potato Processing Plant - Southern Idaho

Process Description. The southern Idaho potato processing industry can be divided into two types of production: frozen and dehydrated. The dehydration process has two different drying methods: drum dryers which result in potato flakes; and fluid bed dryers which are used for potato granule production. These processes have different energy requirements and are examined separately (see Figure 10).

Freezing Process: Raw potatoes are peeled, sorted, and cut to the desired shape in the first section of the freezing process. Iive steam is added in the peeling stage to soften the peel. They are then blanched in approximately $200 \% \mathrm{~F}$ water which has been heated indirectly by steam. Next the potatoes are dried with hot air from natural gas combustion. After drying the potatoes are fried in hot oil at $375^{\circ} \mathrm{F}$.. Heat for the oil fryers is supplied by steam-oil heat exchanger. Finaliy the potatoes are cooled with ambient air and frozen in electrically operated freezers.

Dehydrating Process. In the dehydration process raw potatoes are peeled, sorted, and cut as in the freezing process. Next they are processed to make potato flakes or potato granules. In the flaking process the potatoes are next precooked at $170^{\circ} \mathrm{F}$. After precooking they are dewatered and allowed to cool slightly before entering the cooker. Following the cooking stage the potatoes are riced and rolled into flakes on the drum dryers.

In the granule process the potatoes are blanched at $1800^{\circ}$ after peeling and sorting. They are then cooked at $220^{\circ} \mathrm{F}$. Drying takes place in a three-stage process. The first stage is a flash drying with air at 500-550. $\mathrm{F}$. The second and third stages are fluid bed dryers operating with air at $2500^{\circ} \mathrm{F}$ and $110^{\circ} \mathrm{F}$, respectively.

Energy Requirements: The energy required by potato plants includes electricity and natural gas. The different processes require different percentages of electrical and natural gas as shown in Table 1 .

The energy potentially replaceable by geothermal water in. the frozen process includes steam production at $200^{\circ} \mathrm{F}$ and $350^{\circ} \mathrm{F}$. A geothermal source at $200^{\circ} \mathrm{F}$ could supply $46 \%$ of the process energy requirements and a $350^{\circ} \mathrm{F}$ source could supply up to $85 \%$ (Figure ll). The flake 


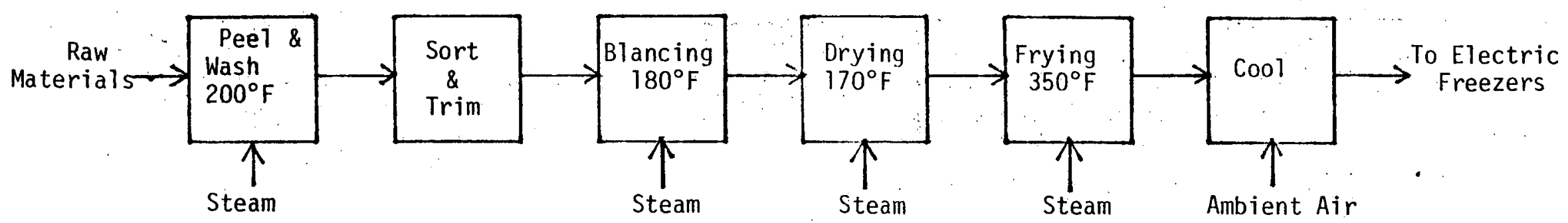

\section{DEHYDRATED-FLAKES}

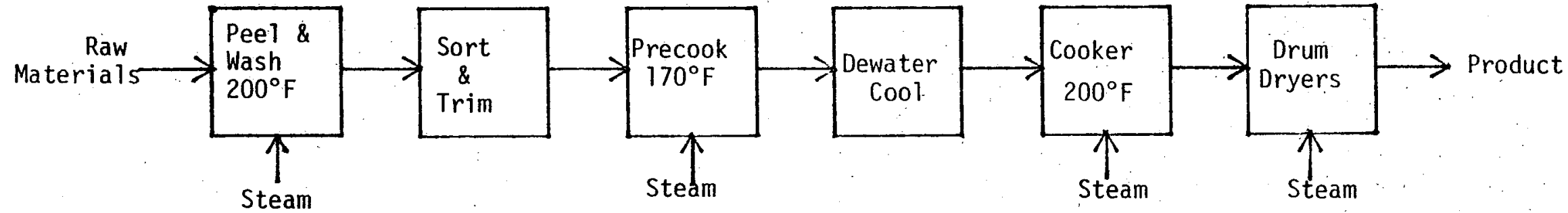

\section{DEHYDRATED-GRANULE}

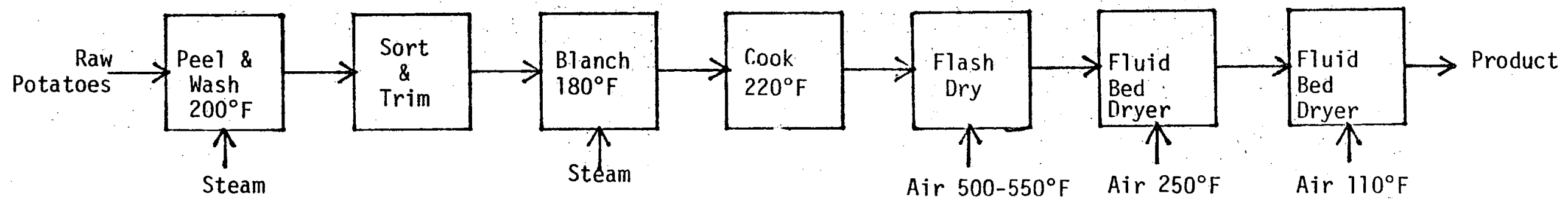

FIGURE 10: POTATO PROCESSING FLOW DIAGRAMS 
TABLE 1

\section{TOTAL ENERGY REQUIREMENTS \\ FOR "TYPICAL" POTATO \\ PROCESSES}

\section{Process Type}

Frozen

Flakes

Granules
Percent of Total Required

Natural Gas

85 웅

$92 \%$

$92 \%$
Electrical

$15 \%$

$8 \%$

$8 \%$

process requires steam at $200^{\circ} \mathrm{F}$ and $400^{\circ} \mathrm{F}$. A geothermal source in the 200 to $400^{\circ} \mathrm{F}$ range could supply $39 \%$ of the process energy requirements while higher geothermal source temperatures could replace up to $92 \%$ of the process's total energy needs (Figure 12). The granule process uses steam at $200^{\circ} \mathrm{F}$ and air heated by natural gas to temperatures ranging from $110^{\circ} \mathrm{F}$ to $550^{\circ} \mathrm{F}$. Figure 13 shows the total amount of the granule process's energy requirements that could be supplied by various geothermal source temperatures. A geothermal source in the $250^{\circ} \mathrm{F}$ to $500^{\circ} \mathrm{F}$ range could supply $60 \%$ of this process's energy requirements.

Geothermal Potential at "Typical Potato Processing Plant. Due to the health regulations the geothermal fluid would have to be treated or would have to be exchanged with a secondary fluid to avoid contact with the product. For the lower temperature applications equipment changes or alterations may be required. The high temperatures could possibly be used to replace natural gas in the main boilers and only this equipment would have to be changed. 
FIGURE 11: POTENTIAL ENERGY SUPPLIED BY GEOTHERMAL IN THE FROZEN PROCESS

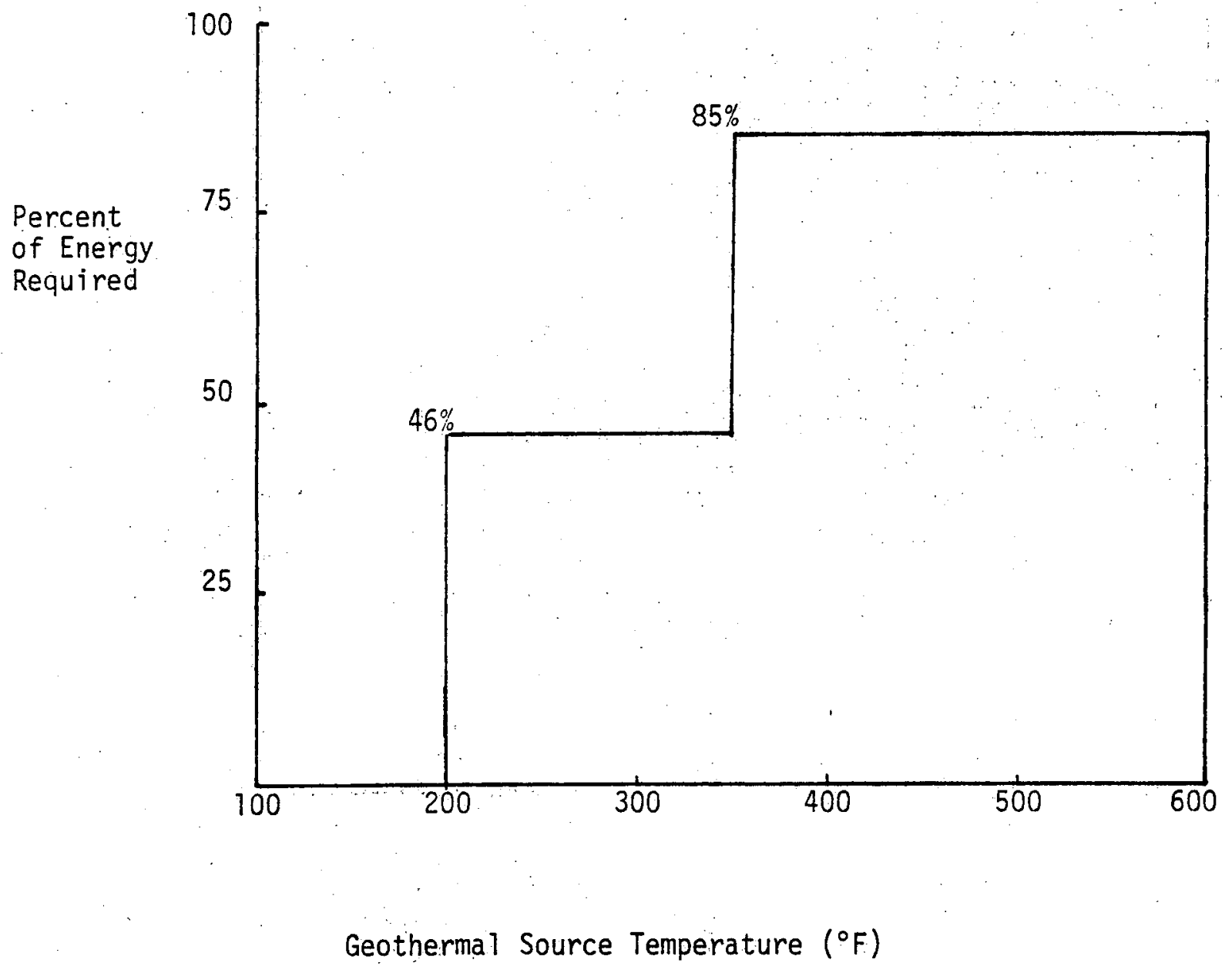


FIGURE 12: POTENTIAL ENERGY SUPPLIED BY GEOTHERMAL IN THE FLAKE PROCESS

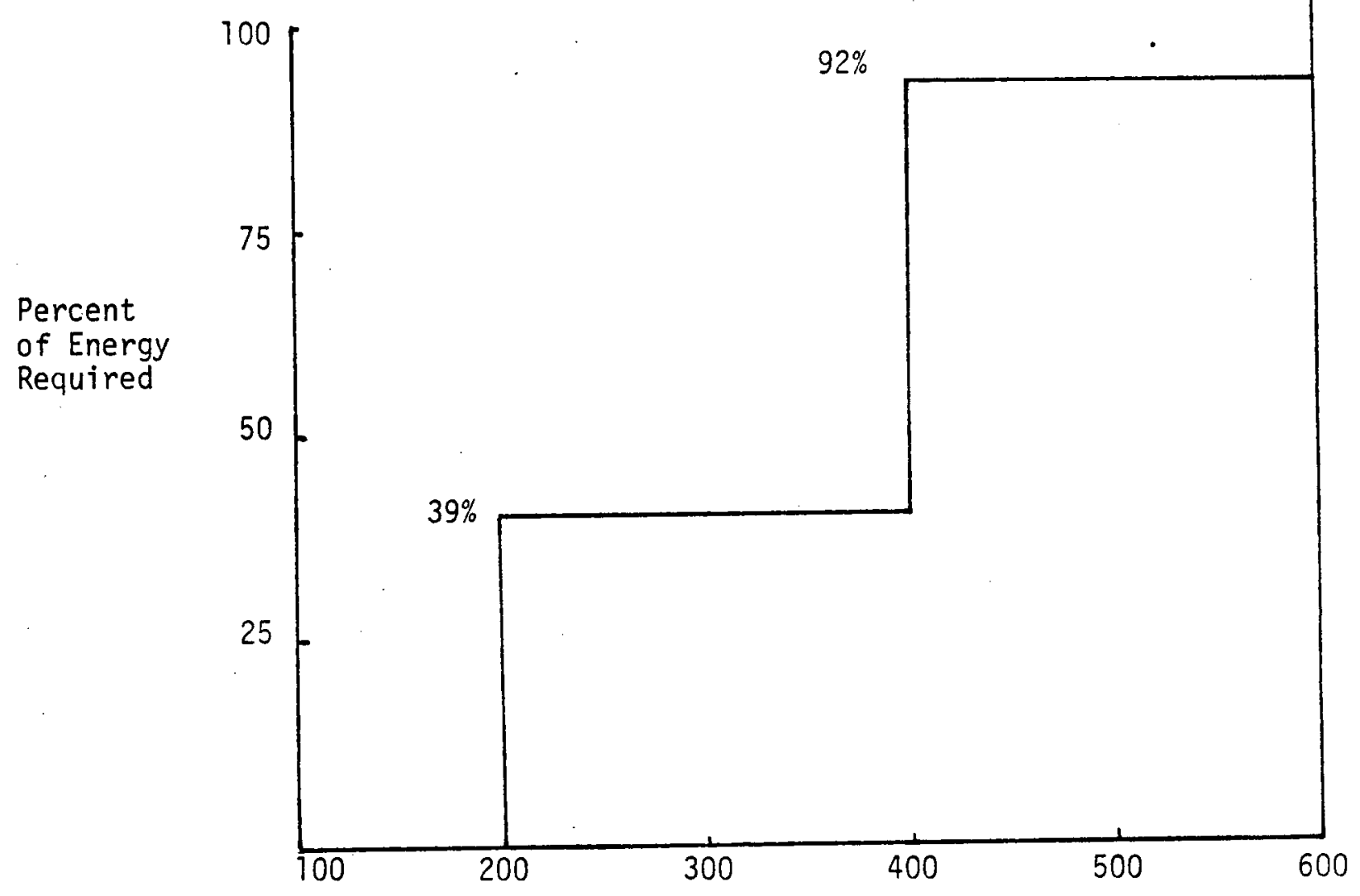

Geothermal Source Temperature $\left({ }^{\circ} \mathrm{F}\right)$ 
FIGURE 13: POTENTIAL ENERGY SUPPLIED BY GEOTHERMAL IN THE GRANULE PROCESS

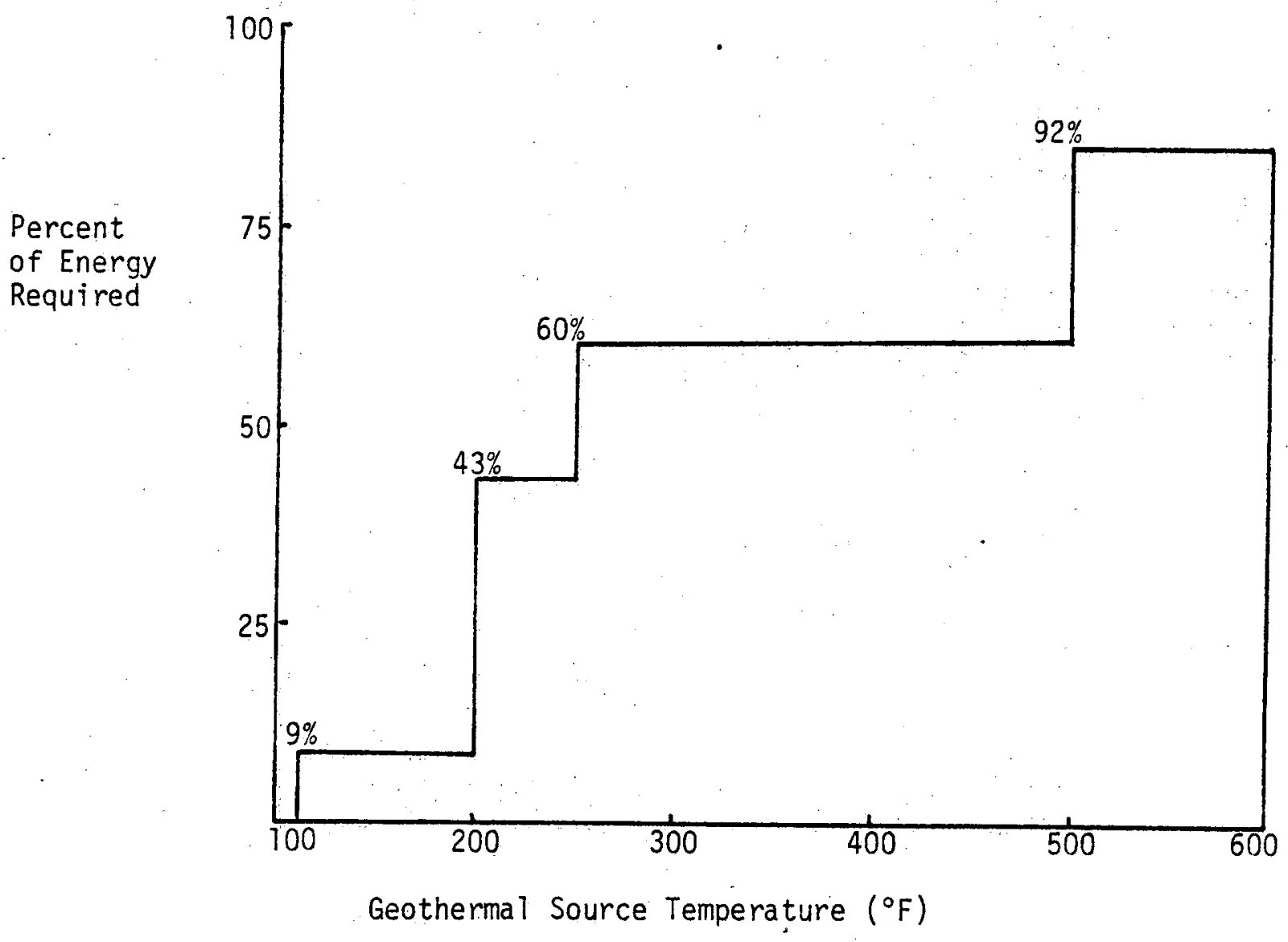


B. Lamb-Weston, Inc., American Falls, Idaho

Process Description. This plant.produces frozen french fries, has browns, and potato flakes; however, $90 \%$ of the production is in the form of french fries. Raw potatoes enter the plant and are peeled, sorted, and cut. The cut potatoes are blanched and then dried with hot air. The potatoes are then fried in oil at $375^{\circ} \mathrm{F}$. The french fries are then cooled with ambient air and frozen in electric freezers. The frozen french fries are then packaged for shipping. Since this plant produces mainly french fries it is examined as a french fry process. (See Figure 14).

Energy Requirements. Lamb-Weston uses natural gas boile rs to produce steam at $400^{\circ} \mathrm{F}$. This steam is used in the $375^{\circ} \mathrm{F}$ fryers and in peeling and blanching operations at $200^{\circ} \mathrm{F}$. Natural gas is also used to provide drying air at $500^{\circ} \mathrm{F}$. The freezers require $3.0 \mathrm{Mw}$ of electricity. Figure 15 shows the amount of energy reolaceable by various geothermal temperatures.

Geothermal Potential at Lamb-Weston. Due to hot air drying instead of steam drying the energy profile for this company is slightly different from the typical potato plant. Geothermal energy could be of use if it is hot enough to be used as the main boiler energy source $\left(400^{\circ} \mathrm{F}\right)$. The lower temperature applications would require some equipment modifications to meet health regulations and prevent contamination of the product with the geothermal source. For example, some cooking operations presently using live steam can be done using jacketed kettles.

C. Summary of Remaining Potato Processing Plants in Southeastern Idaho

Process Description. These plants are categorized into three process types: frozen, dehydrated flakes, and dehydrated granules. Table 2 summarizes the plants and their process types.

Flow Diagram. The flow diagrams for potato processing plants are similar and will be represented by the process types shown in the "typical" processing section.

Energy: Requirements. The energy requirements for these plants are given in the "typical" processing section according to process type. 


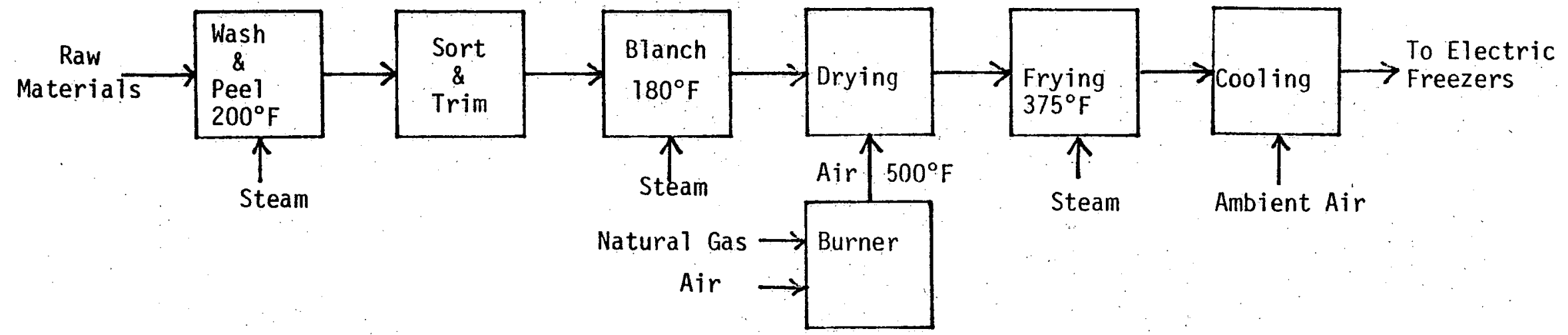

FIGURE 14: GENERAL FLOW DIAGRAM FOR LAMB-WESTON 
TABLE 2: POTATO PROCESSING PLANTS

IN SOUTHEASTERN IDAHO

Company

American Potato Company

Blackfoot, ID

Idaho Fresh Pak

Lewisville, ID

Idaho Frozen Foods, Inc.

Twin Falls, ID

Idaho Supreme Potatoes, Inc.

Firth, ID

J.R. Simplot Co.

Aberdeen, ID

Type

Granule

345

Flake

650

Frozen

520

Flake

220

J.R. Simplot Co.

Burley, ID

Frozen

345

J.R. Simplot Co.

Heyburn, ID

Frozen

650

Magic Valley Foods

Rupert, ID

Granule

650

Nonpareil Processing

Blackfoot, ID

Lamb-Weston, Inc.

American Falls, ID

Ore-Ida Foods, Inc.

Burley, ID

Pro-Idah Foods, Inc.

Ririe, ID

Rogers Bros. Company

Rexburg, ID

Granule

Granule

650

Shelley, ID

Roger Bros. Company

Idaho Falls, ID

Flake

220

Frozen

650

Frozen

860

Flake

Flake

175
Total Energy

Req'd (109 BTU/Yr) 
FIGURE 15: POTENTIAL ENERGY SUPPLIED BY GEOTHERMAL

Percent of Energy Required

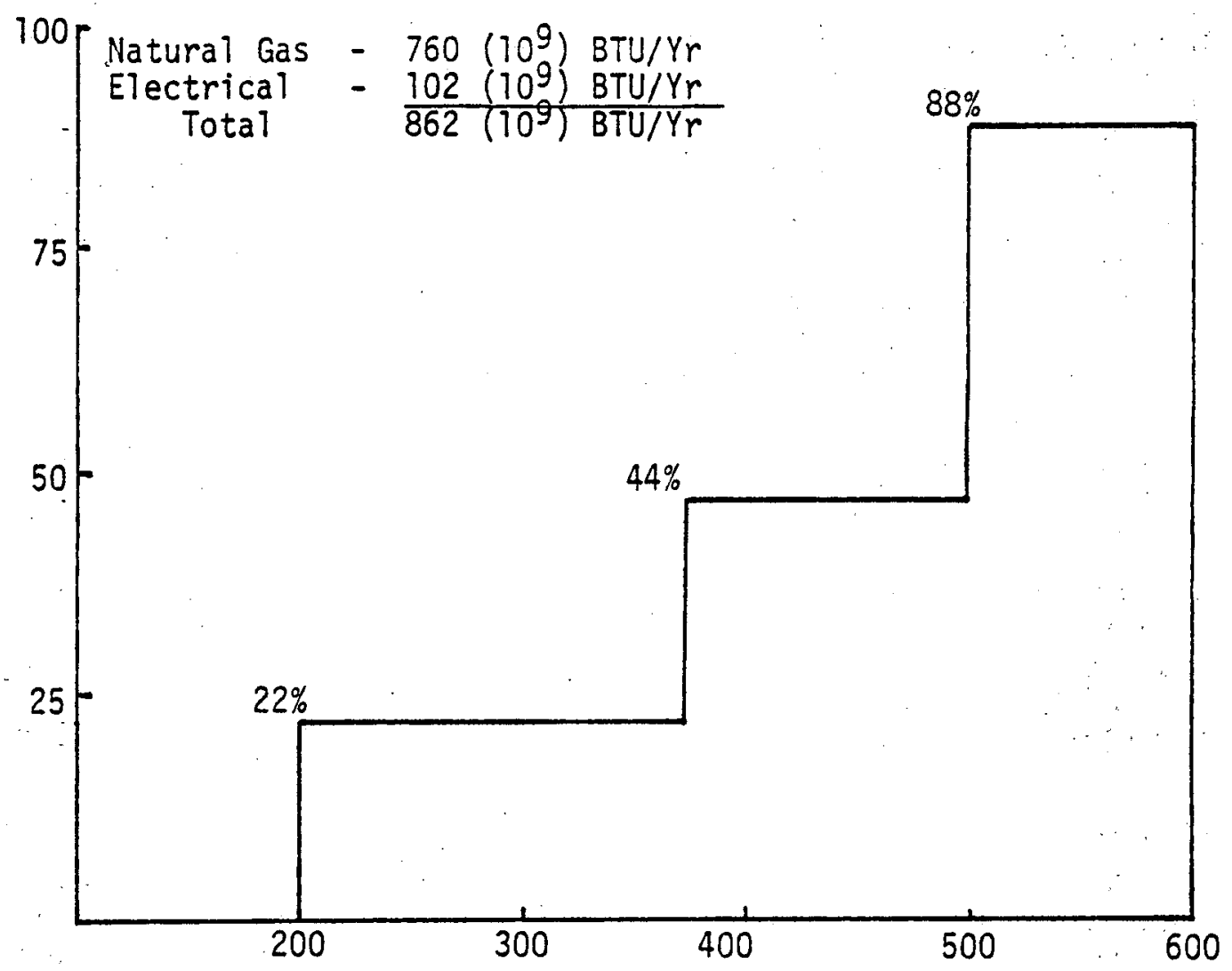

Geothermal Source Temperature $\left({ }^{\circ} \mathrm{F}\right)$

Present Energy Usage. Table 2 lists the total amount of energy required by each plant and this can be used in conjunction with the information about "typical" plants to obtain specific requirements for each plant. Figures $11-13$ show the total energy required for each type of processing. These figures also show the amount of energy replaceable by geothermal at a given plant for a known geothermal source temperature.

Figure 16 summarizes the potential use of geothermal energy in the plants listed in Table 2. A geothermal source in the $2000 \mathrm{~F}$ to $300^{\circ} \mathrm{F}$ range could supply these plants with over $3000\left(10^{9}\right)$ BTU/Yr. of energy. This would require a total flow of at least 3000 gallons per minute. 
FIGURE 16: TOTAL ENERGY USED FOR THE POTATO PROCESSING INDUSTRY

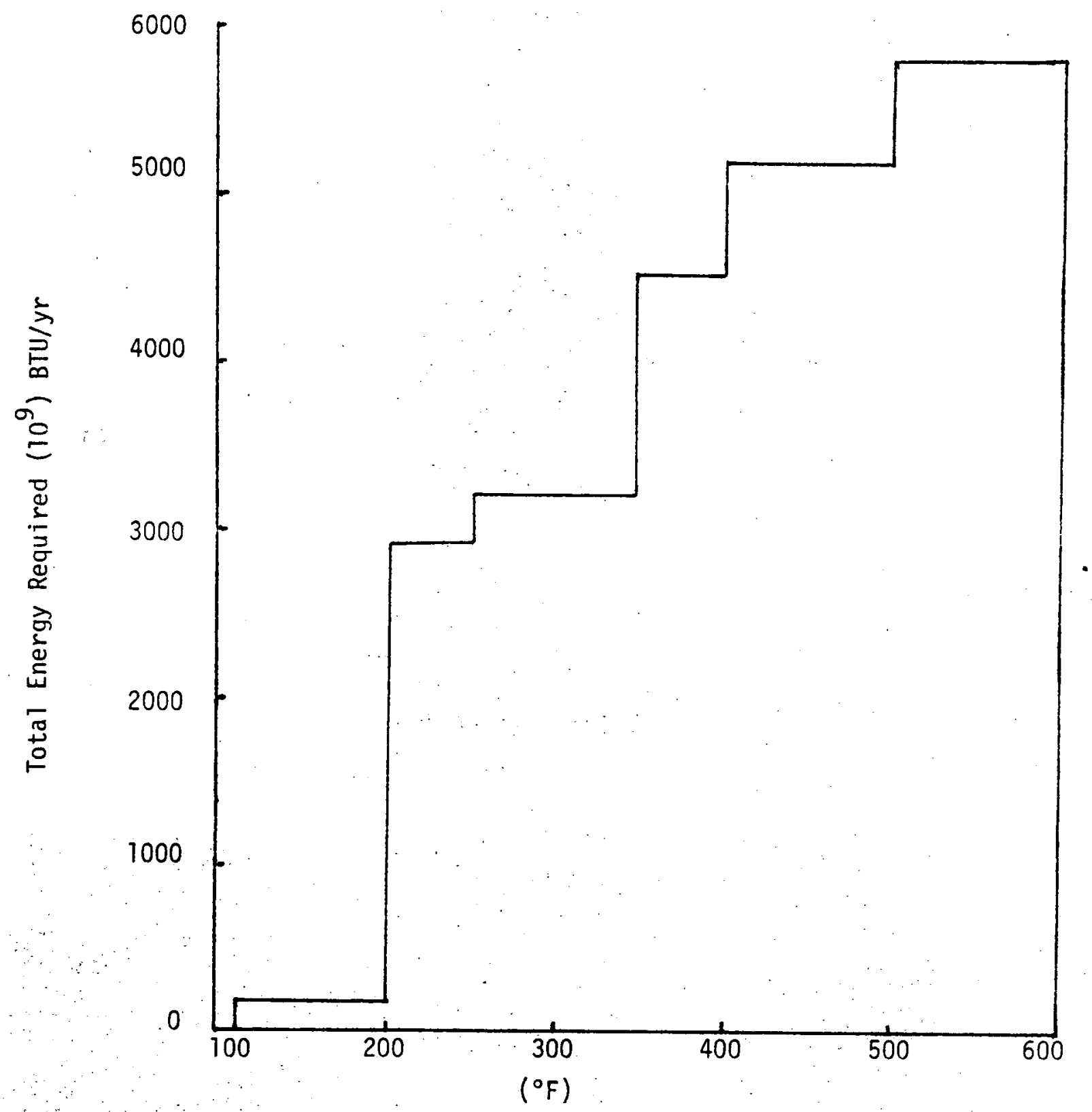

Energy Source Temperature 


\section{ENERGY EXPLORATION IN SOUTHEAST IDAHO}

\section{Known Geothermal Resources Prospects}

Thermal springs and wells in Southeast Idaho generally share several characteristics including high total dissolved solids, high $\mathrm{HCO}_{3}$ content and generally precipitate $\mathrm{CaCO}_{3}$ in the form of travertine (Mitchell, Anderson and Johnson, 1979). This area. also is endowed with certain geological characteristics which favor the occurrence of geothermal energy.

Southeastern Idaho is within an earthquake activity area known as the Intermountain Seismic Belt. (Smith and Sbar, 1974). This seismic zone is interpreted to be a boundary between subplates of the greater North American crustal plate, where differential movements between the Rocky Mountain province and the Basin and. Range province are taking place. (Smith and Sbar, 1972). Subplate boundaries are generally excellent areas for prospecting for geothermal resources. In Idaho, the approximate axis of the belt passes near preston in Franklin County, through soda Springs in Caribou County to Driggs in Teton County and up into the Yellowstone Park area (Mitchell, Anderson and Johnson, 1979). This area consists of predominantly, block faulted mountain ranges, arranged in a north-south echelon pattern, across a region of low angle thrust faults. The area has characteristically youthful. magmatic activity, areas of high heat flow, and thermal spring activity. Thermal springs are widely distributed through this region: and wells have encountered thermal watèr locally. Most springs are associated with known faulting or lineaments. Five potential high temperature prospect areas have been identified and there is significant potential for additional high temperature areas being discovered as more detailed geological data becomes known. Table 3 lists the five known high temperature geothermal. prospecting areas in Southeast Idaho. Table 4 lists the geothermal well permits that have been issued in southeast Idaho by the Idaho Department of Water Resources. A Geothermal Well Permit is a drilling permit which is issued specifically for exploration of high temperature resources.

In addition to the geothermal well permits listed in Table 4 , the Federal Department of Energy has drilled several geothermal exploration wells at Raft River K.G.R.A. in Cassia County. These wells have proven a $147^{\circ} \mathrm{C}$ geothermal resource. A pilot $5 \mathrm{MW}$ electrical generation plant is currently under construction. In addition to electric power generation, this site has potential for direct applications for industrial processing. A DOE geothermal exploration well drilled at the Idaho National Engineering Laboratory in Butte County, although a dry hole, proved high temperatures exist at a depth of 3,000 meters in the Snake River Plain. 
TABLE 3

High Temperature Geothermal Prospects in Southeast Idaho

Geothermal site County

Eattle Creek.H.S. Franklin

Big Creek H.S. -Lemi

Biackfoot

Reservoir

Magic Reservoir

Blaine-

Camas

Cassia

Raft River

\section{Location}

T. 15: S.. R. 39 E. Sec: 8

T: $23, \mathrm{~N}:$ R: $19 . \mathrm{E}$, Sec. 22

T. 6. S.. R. $41 \mathrm{E}$. Sec. 19

T. 1. S., R. $17 \mathrm{E}$. Sec. 23 ?

T. $15 \mathrm{~S} ., \mathrm{R} .26 \mathrm{E}$. Sec. 23
Land Ownership

Private

U.S.F.S.

Pivate, BLM, BIA

Private, BLM

BLM

Measured Best Estimate* Types of Development Temp* ${ }^{\circ} \mathrm{C}$ Subsurface ${ }^{\circ} \mathrm{C}$ speculated and Notes

$\therefore \quad \therefore \quad . \quad \therefore$

- Iâho Department of Water Resources, Bulletin 30, 1979.

*** Fuip Test. Temperatures at the Raft River Geothermal Test site.

91

.

42

72

$147 *$ *
250

\section{5}

240

174

147
Electrical Generation

(ivet steam), Injustrial

Food processing, Casanol

Electrical Cencration (Wet steam), Institutional Restrictions

Electricel. Garcration (Possible), insed on ary oil exploxation viell

Electrical Gencration (Binary), Incustrial

Processing

Electricai Einary Plant uncier construction., Gasainol 
GEOTHERMAL .WELL PERMITS

$$
\text { EAST OF R. } 20 \mathrm{E} \text {. }
$$

\section{Permit Number}

$13-G R-1$

$13-G R-2$

$27-G R-1$

21-GR-1

$2 i-G R-2$

\section{Applicant}

SUNOCI

John Warrick

White Water Development Company

Occidental Geothermal, Inc.

Occidental Geothermal; Inc.

\section{Well Name}

CH. STOCKS No. 1

No. 1

Dropped

Strum No. 1

Egbert Farms No. 1
Location

NESW S6 T15S R39E

NESE S7 T14S R39E

SWNW.S25 T5S R36E

NENE S23 T9N R42E

SWNW S19 T9N R43E 
A key factor in the development of geothermal energy for industrial locations in Southeast Idaho is the location of the resource exploration areas with respect to the industrial sites. The Idaho Department of Water. Resources has identified several geothermal areas with potential for high temperature resources capable of industrial application. Also, private industry has leased large tracts of state and federal lands throughout Idaho for geothermal exploration and oil and gas exploration. Because oil and gas exploration areas in Southeast Idaho are also good prospects for geothermal resources, exploration for oil and gas must be considered when assessing the regional potential for geothermal energy development. Several oil and gas exploration wells have been drilled in southeast Idaho and large tracts of state and federal lands have been leased.

Recent oil and gas exploration drilling activity has shown high temperature geothermal potential.

In general, the region is considered to have good potential for moderate to high temperature geothermal resources. High temperature geothermal resources. Which are capable of industrial processing $\left(147^{\circ} \mathrm{C}\right)$ have been proven at Raft River KGRA in Cassia County and deep exploration wells in Butte and Bonneville Counties indicate high temperatures $\left(250^{\circ} \mathrm{C}\right)$ exist at depths of 3,000 meters. Geochemical analysis of hot springs in Franklin county indicate resource temperatures of $250^{\circ} \mathrm{C}$ are possible at depth.

Data regarding the current status of exploration and leasing activity for geothermal, oil and gas, and phosphate resources was compiled to assess the intensity of exploration interest in Southeast Idaho. Exploration drilling activity was also inventoried to gauge the degree of exploration. This information was compiled into tabular and map form be commodity.

Tables 5 and 6 list the current status of geothermal leasing activity on State and Federal lands in Southeast Idaho. Table 7 is a summary of State of Idaho oil and gas leasing by lessee in Southeast Idaho. Table 8 is a summary of Federal oil and gas leasing by lessee in Southeast Idaho. Table 9 is a status registry of oil and gas drilling activity in Southeast Idaho.

This list is derived from the oil and Gas Drilling Register maintained by the Idaho Department of Lands, and covers drilling East of R. 20. E. only. The information gives the location, principal drilier, well name, date of drilling, depth drilled, logs on record, county, and additional remarks on well status.

Leasing and exploration drilling activity in Southeast Idaho has increased intensity in recent years. This surge in exploration activity is largely due to successful oil exploration in Wyoming and Utah: 
Continued oil and gas exploration and geothermal exploration in the region could prove a new energy source which could be used by the local industrial market. The majority of the leasing exploration activity is located South of the snake River Plain where the major industries are phosphate mining and processing. Tables 10 and 11 list the location of the major state and Federal phosphate leases in Southeast Idaho. The future development of these phosphate leases is partially dependent on adequate energy supplies.

The data presented in Tables 3 through 11 has been plotted on a map to illustrate the geographic relationships between current industries and energy exploration in Southeast Idaho: (See map appendix.)

\section{Conclusions}

Although Southeast Idaho is considered a good location for geothermal exploration, the potential for high temperature geothermal fluids is unknown.

High temperature geothermal résources capable of electric power generation and direct industrial applications are probable throughout the region but have been commercially developed only at Raft River in Cassia County. Extensive exploration for oil, gas, and geothermal could discover additional high temperature $\left(150^{\circ} \mathrm{C}\right)$ resources.

- Development of high temperature geothermal fluids for power production will most likely be limited to small generation (5 MW) facilities, similar to the D.O.E. Raft River facility. Development of high temperature fluids $\left(100^{\circ} \mathrm{C}\right.$ to $\left.150^{\circ} \mathrm{C}\right)$ for direct industrial applications will depend upon the resources location. Because these fluids must be used within close proximity to the wellhead, current industries will be limited to exploring locally. The development of new industrial parks at geothermal well sites will be limited by accessability to current transportation facilities. 


\section{TABLE 5}

\section{STATE GEOTHERMAL LEASES}

EAST OF R. 20 E.

\section{State geothermal leasing data was compiled from the index} file of State Geothermal Leases maintained by the Idaho Department of Lands. The information is presented by lessee, and gives the lease number, location (resolution of one section), acreage, and county. AlI ' $H$ ' numbered leases were issued in 1975. The remainder have the date of issue as the last two digits of the lease number. This list covered only those leases east of R. $20 \mathrm{E}$.

ANADARKO PRODUCTION CO.

Total Acres: 12,612

BOX 1330

Houston, TX 77001

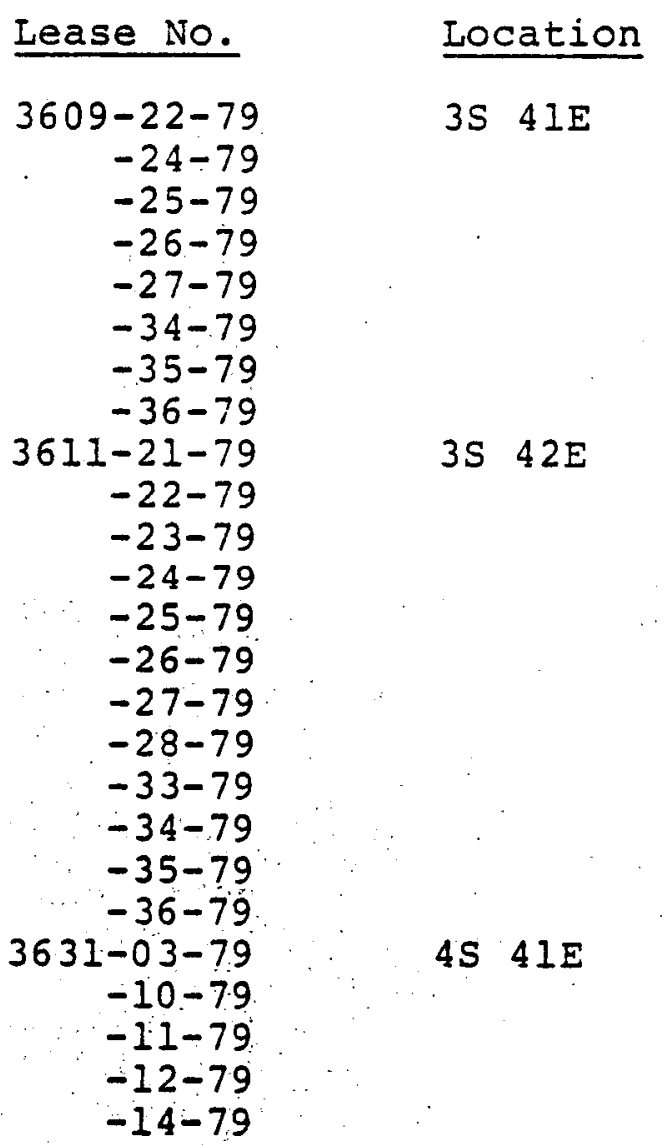

\begin{tabular}{l} 
Sec. \\
22 \\
24 \\
25 \\
26 \\
27 \\
34 \\
35 \\
36 \\
21 \\
22 \\
23 \\
24 \\
25 \\
26 \\
27 \\
28 \\
33 \\
34 \\
35 \\
36 \\
3 \\
10 \\
11 \\
12 \\
14 \\
\hline 1
\end{tabular}

Acres

320

400

640

400

430

640

200

640

400

640

640

611

623

640

640

160

280

480

640

635

543

640

440

240

640

\section{County}

Bingham

Bingham

Bingham

Bingham

Bingham

Bingham

Bingham

Bingham

Bonneville

Bonneville

Bonneville

Bonneville

Bonneville

Bonneville

Bonneville

Bonneville

Bonneville

Bonneville

Bonneville

Bonneville

Bingham

Bingham

Bingham

Bingham

Bingham 
KENNETH M. BRITT

Box 810

Jackson, MS 39205

Lease No.

2983-03-79

$-11-7.9$

$-12-79$

$2985-18-79$

$-17-79$

$-18-79$

$-19-79$

$-20-79$

$-21-79$

$4699-36-78$

$4825-36-78$

$4829-16-78$

$-36-78$

$4909-16-78$

$4911-16-78$

$-24-78$

$-25-78$

$-26-78$

$-35-78$

$-36-78$
Location Sec.

$4 N \quad 40 E$

4N $41 E$

14S $27 \mathrm{E}$

15S 25E

I5S $27 \mathrm{E}$

16S 26E

16S $25 E$
3

11

12

16

17

18

19

20

21

36

36

16

36

16

16

24

25

26

35

36
W Subtotal 11,949

E Subtotal 11,563

Total Acres $\overline{23,512}$
Acres

560

360

440

640

640

521

642

480

640

640

640

640

640

640

640

520

440

640

560

640
County

Madison

Madison

Madison

Madison

Madison

Madison

Madison

Madison

Madison

Cassia

Cassia

Cassia

Cassia

Cassia

Cassia

Cassia

Cassia

Cassia

Cassia

Cassia
REUBEN BULLOCK

BOX: 370

Cody, WY 82414

Lease No.

$\mathrm{H}-473$
Iocation

$12 \mathrm{~N} 42 \mathrm{E}$ $\underline{\text { Sec. }}$

16
(E) Sub total

(W) sub total Total Acres

Acres

640
640

1578

$\overline{2218}$

County

Fremont

CHEVRON U.S.A., INC.

BoX 599

Denver, Co 80201

Total Acres: $\quad 10,562$

Lease No.

Location

Sec.

Acres

County

H -421

$3 \mathrm{~N} .40 \mathrm{E}$

$\mathrm{H}-422$

$3 \mathrm{~N} \quad 40 \mathrm{E}$

330

$\frac{1}{2}$

13

$3 N \quad 40 E$
$3 N \quad 40 E$

14

Bonnevilie

Bonneville

280 
CHEVRON, U.S.A., INC. (Continued)

\begin{tabular}{|c|c|c|c|}
\hline $\begin{array}{c}\text { Lease No. } \\
H=425\end{array}$ & $\begin{array}{l}\text { Location } \\
3 \mathrm{~N} 40 \mathrm{E}\end{array}$ & $\underset{15}{\text { Sec. }}$ & $\begin{array}{l}\text { Acres } \\
440\end{array}$ \\
\hline$H-426$ & $4 \mathrm{~N} 40 \mathrm{E}$ & 22 & 38 \\
\hline $\mathrm{H}-427$ & $4 N \quad 40 E$ & 23 & 92 \\
\hline $\mathrm{H}-428$ & $4 N 40 E$ & 25 & 92 \\
\hline $\mathrm{H}-429$ & $4 \mathrm{~N} \quad 40 \mathrm{E}$ & 26 & 184 \\
\hline $\mathrm{H}-430$ & $4 \mathrm{~N} \quad 40 \mathrm{E}$ & 36 & 198 \\
\hline $\mathrm{H}-43 \mathrm{I}$ & $3 N 41 E$ & 5 & 94 \\
\hline $\mathrm{H}-432$ & $3 N \quad 41 E$ & 6 & 139 \\
\hline$H-433$ & $3 N \quad 41 E$ & 8 & 54 \\
\hline$H-434$ & $3 N \quad 41 E$ & 9 & 22 \\
\hline$H-435$ & $3 N \quad 4 I E$ & 16 & 640 \\
\hline$H-436$ & $3 N \quad 4 I E$ & 17 & 160 \\
\hline $\mathrm{H}-437$ & $4 N \quad 41 E$ & 31 & 56 \\
\hline$H-438$ & $4 N \quad 41 E$ & 32 & 6 \\
\hline$H-430$ & $14539 E$ & 36 & 40 \\
\hline $\mathrm{H}-440$ & $15 S 39 E$ & 1 & 160 \\
\hline $3626-16-79$ & $4 S \quad 42 E$ & 16 & 240 \\
\hline $3631-13-79$ & $4 S 41 E$ & 13 & 640 \\
\hline$-24-79$ & $4 S \quad 41 E$ & 24 & 641 \\
\hline$-25-79$ & 4S $4 I E$ & 25 & 600 \\
\hline$-36-79$ & $4 S \quad 41 E$ & 36 & $64 \mathrm{C}$ \\
\hline $3817-01-79$ & SS $41 E$ & 1 & 642 \\
\hline $3819-06-79$ & $5 S 42 E$ & 6 & 644 \\
\hline $3877-21-79$ & $6 S 42 E$ & 21 & 640 \\
\hline$-28-79$ & $6 S \quad 42 E$ & 28 & 640 \\
\hline$-29-79$ & $6 S .42 E$ & 29 & 360 \\
\hline$-32-79$ & $6 S \quad 42 E$ & 32 & 240 \\
\hline $4025-08-79$ & $7 S \quad 41 E$ & 8 & 640 \\
\hline $4027-20-79$ & $7 S \quad 42 E$ & 20 & 640 \\
\hline
\end{tabular}

County

Bonneville

Madison \& Jefferson

Madison \& Jeffersin

Madison \& Jefferson.

Madison \& Jefferson

Madison \& Jefferson

Bonneville

Bonneville

Bonneville

Bonneville

Bonneville

Bonneville

Madison

Madison

Franklin

Franklin

Bonnevilie

Bingham

Bingham

Bingham

Bingham

Caribou

Caribou

Caribou

Caribou

Caribou

Caribou

Caribou

Caribou

RICHARD C. HOEFLE

BOX 611 .

Billings, Montana 59103

Total Acres: 7040

\begin{tabular}{|c|c|c|c|c|}
\hline Lease No. & Eocation & sec. & Acres & County \\
\hline $\begin{array}{r}3835-16-79 \\
-20-79 \\
-21-79 \\
-29-79 \\
-32-79 \\
-36-79 \\
4029-16-79 \\
-17-79 \\
-21-79 \\
-28-79 \\
-36-79\end{array}$ & 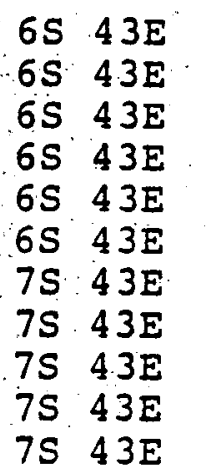 & $\begin{array}{l}16 \\
20 \\
21 \\
29 \\
32 \\
36 \\
16 \\
17 \\
21 \\
28 \\
36\end{array}$ & $\begin{array}{l}640 \\
640 \\
640 \\
640 \\
640 \\
640 \\
640 \\
640 \\
640 \\
640 \\
640\end{array}$ & $\begin{array}{l}\text { Caribou } \\
\text { Caribou } \\
\text { Caribou } \\
\text { Caribou } \\
\text { Caribou } \\
\text { Caribou } \\
\text { Caribou } \\
\text { Caribou } \\
\text { Caribou } \\
\text { Caribou } \\
\text { Caribou }\end{array}$ \\
\hline
\end{tabular}


OCCIDENTAL GEOTHERMAL, INC. 5000 Stockdale Hwy

Bakersfield, CA 93339

Lease No.

$\mathrm{H}-151^{\circ}$

$\mathrm{H}-153$

$\mathrm{H}-156$

$\mathrm{H}-157$

$\mathrm{H}-158$

$\mathrm{H}-160$

$\mathrm{H}-161$

$\mathrm{H}-163$

$\mathrm{H}-164$

$\mathrm{H}-1.65$

$\mathrm{H}-166$

$\mathrm{H}-1.67$

$\mathrm{H}-1.6 .8$

$\mathrm{H}-169$

$\mathrm{H}-762$

$\mathrm{H}-764$

H- -767

$\mathrm{H}-768$

$\mathrm{H}-769$

$\mathrm{H}-770$

$\mathrm{H}-771$

$\mathrm{H}-.773$

$\mathrm{H}-774$
Location

IIN $41 E$

11N $42 \mathrm{E}$

$12 \mathrm{~N} \quad 42 \mathrm{E}$

$13 \mathrm{~N} .2 \mathrm{E}$

$13 \mathrm{~N} 42 \mathrm{E}$

$12 \mathrm{~N} 43 \mathrm{E}$

$13 \mathrm{~N} 43 \mathrm{E}$

$13 \mathrm{~N} 44 \mathrm{E}$

$13 \mathrm{~N} 44 \mathrm{E}$

$13 \mathrm{~N} \quad 44 \mathrm{E}$

$13 \mathrm{~N} 44 \mathrm{E}$

$13 \mathrm{~N} 44 \mathrm{E}$

$13 \mathrm{~N} 44 \mathrm{E}$

$13 \mathrm{~N} 44 \mathrm{E}$

IIN $41 \mathrm{E}$

IIN $42 \mathrm{E}$

10N $43 \mathrm{E}$

1ON $43 E$

IIN $43 E$

IIN 43E

$12 \mathrm{~N} 43 \mathrm{E}$

$13 \mathrm{~N} \quad 43 \mathrm{E}$

$10 \mathrm{~N} 44 \mathrm{E}$
Subtotal. (w)

subtotal (e).

Total Acres

Acres

640

640

323

440

640

640

640

80

160

320

640

262

320

640

640

640

640

640

640

648

640

640

640
16,453

$\frac{12,153}{28,606}$

County

Fremont

Fremont

Fremont

Fremont

Fremont

Fremont

Fremont

Fremont

Fremont

Fremont

Fremont

Fremont

Fremont

Fremont

Fremont

Fremont

Fremont

Fremont

Fremont

Fremont

Fremont

Fremont

Fremont

PHILLIPS PETROLEUM CO. Box 239

Salt Lake City, Utah 84110

Total Acres: 58,306

\begin{tabular}{|c|c|c|c|c|}
\hline Lease No. & Iocation & sec. & Acres & Counti \\
\hline $\begin{array}{r}2189-16-79 \\
2189-36-79 \\
2191-36-79 \\
2347-36-79 \\
2349-16-79 \\
2351-16-79 \\
2401-16-79 \\
2403-36-79 \\
2983-01-79 \\
-02-79 \\
-10-79 \\
2985-01-79 \\
-02-79 \\
-09-79 \\
-10-79\end{array}$ & $\begin{array}{rl}11 N & 33 E \\
11 N & 33 E \\
11 N & 32 E \\
10 N & 32 E \\
10 N & 33 E \\
10 N & 34 E \\
9 N & 34 E \\
9 N & 33 E \\
4 N & 40 E \\
4 N & 40 E \\
4 N & 40 E \\
4 N & 41 E \\
4 N & 41 E \\
4 N & 41 E \\
4 N & 41 E\end{array}$ & $\begin{array}{r}16 \\
36 \\
36 \\
36 \\
16 \\
16 \\
16 \\
36 \\
1 \\
2 \\
10 \\
1 \\
2 \\
9 \\
10\end{array}$ & $\begin{array}{l}640 \\
640 \\
602 \\
640 \\
640 \\
640 \\
640 \\
640 \\
280 \\
320 \\
280 \\
641 \\
642 \\
400 \\
400\end{array}$ & $\begin{array}{l}\text { Clark } \\
\text { Clark } \\
\text { Clark } \\
\text { Clark } \\
\text { Clark } \\
\text { Clark } \\
\text { Clark } \\
\text { Clark } \\
\text { Madison } \\
\text { Madison } \\
\text { Madison } \\
\text { Madison } \\
\text { Madison } \\
\text { Madison } \\
\text { Madison }\end{array}$ \\
\hline
\end{tabular}


PHILIIPS PETROLEUM CO. (Continued)

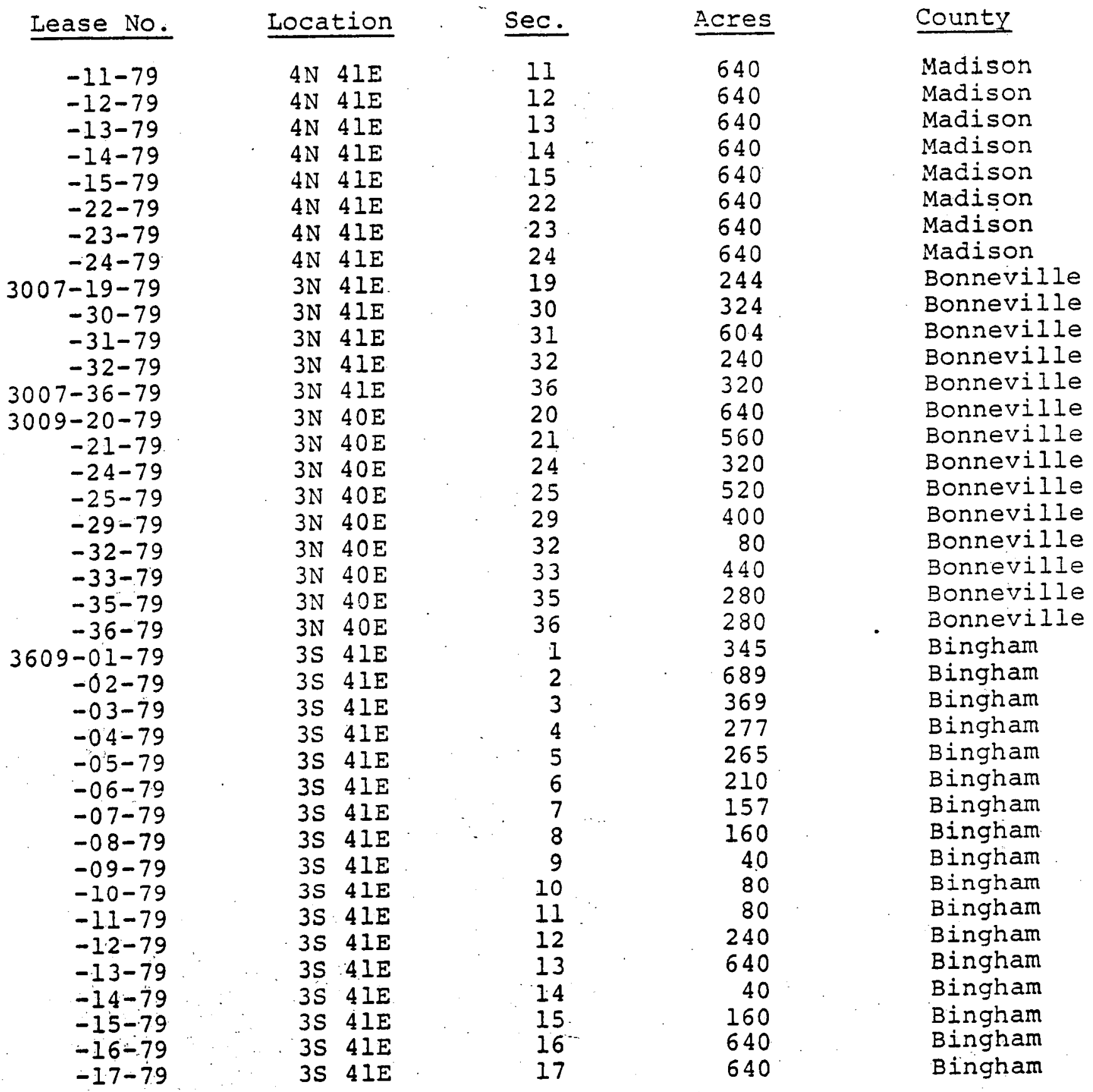


PHILLIPS (cont.)

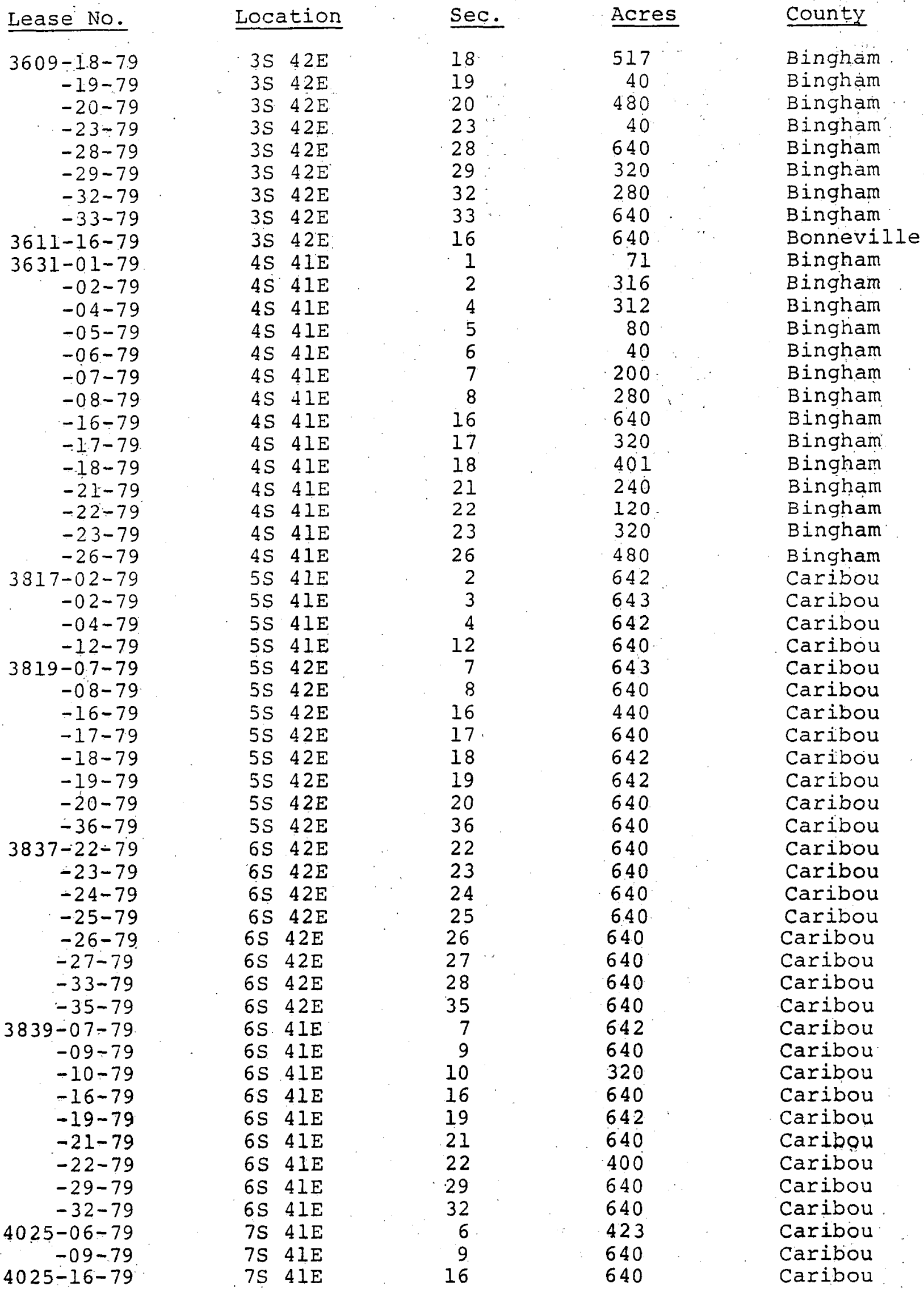


PHILIIPS (cont.)

Lease No.

$4025-15-79$

$4027-17-79$

$-25-79$

$-26-79$

$-32-79$

$-35-79$

$-36-79$

$4851-05-79$

$-08-79$

$-16-79$

$-17-79$
Location

$75 \quad 41 \mathrm{E}$

$7 S \quad 42 \mathrm{E}$

$7 S \quad 42 \mathrm{E}$

$7 \mathrm{~S} 42 \mathrm{E}$

$7 S \quad 42 E$

$7 S \quad 42 \mathrm{E}$

$7 S \quad 42 \mathrm{E}$

15S $38 \mathrm{E}$

$15 S 28 \mathrm{E}$

$15 S \quad 28 \mathrm{E}$

15S $28 \mathrm{E}$

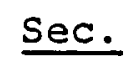

18

17

25

26

32

35

36

5

8

16

17
Acres

320

640

640

320

640

320

560

486

640

600

480
County

Caribou

Caribou

Caribou

Caribou

Caribou

Caribou

Caribou

Franklin

Franklin

Franklin

Franklin

Subtotal (e) 55,391

Subtotal (w) $\quad 2,915$

TOTAL ACRES $\quad 58,306$

RAFT RIVER RURAL ELECTRIC COOPERATIVE, INC. TOtal ACres: 1280 BOX 617

Malta, ID 83342

Lease No.

$\mathrm{H}-754$

HO 755
Location

$14 S \quad 26 E$

15S $26 E$
Sec.

36

16
Acres

640

640
County

Cassia

Cassia

SOUTHLAND ROYALTY CO.

1000 Fort Worth club Tower

Fort Worth, Texas 76102

Lease No.

$4467-13-79$
Location

$12 S 39 \mathrm{E}$
Sec.

13
Acres

640
County

Franklin 
LAURA J. SPANGLER

2827 Venus Place

Boise, Idaho 83704

Lease No.

$2383-16-79$

$-25-79$

$-26-79$

$-36-79$
Location

$9 N \quad 43 E$

$9 N \cdot 43 E$

$9 N 43 E$

$9 N \quad 43 E$

Total Acres: 640

SUNOCO ENERGY DEVELOPMENT CO.

12700 Park Central Place, Suite 1500

Total Acres: 2800

Dallas, Texas 75251

Lease No.

$\mathrm{H}-787$

$\mathrm{H}-789$

$\mathrm{H}-790$

$\mathrm{H}-791$

$\mathrm{H}-792$
Location

$.13 \mathrm{~S} 26 \mathrm{E}$

I5S 26E

$14 S \quad 27 \mathrm{E}$

16S 27E

$14 \mathrm{~S} 38 \mathrm{E}$
Sec.

16

25

26

36
Acres

400

120

40

80
County

Fremont Fremont Fremont Fremont
County

Cassia

Cassia

Cassia

Cassia

Cassia 
10300 North Central Expwy.

Building $V$, Fifth Floor

Dallas, $\mathrm{TX} 75231$

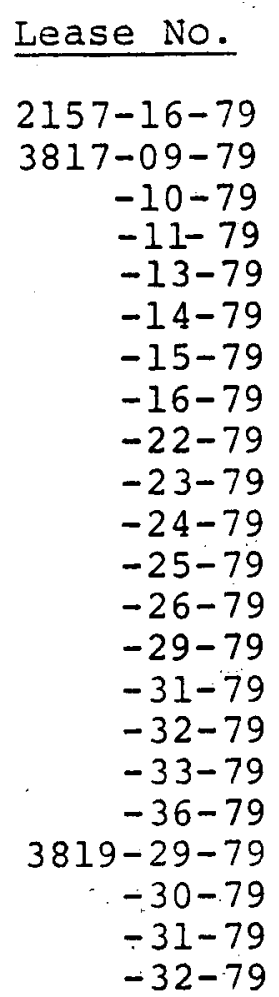

$3837-13-79$

$-14-79$

$-16-79$

$-20-79$

$-34-79$

$-36-79$

$3839-03-79$

$-0.4-79$

$-08-79$

$-15-7.9$

$-17-79$

$-18-79$

$-20-79$

$-28-79$

$-30-79$

$-31-79$

$4025-0.4-7.9$

$-0.5-79$

$-07-79$

$4025-17-79$

$-19=79$

$-36-79$

$4027-01-79$

$-02-79$

$-03-79$

$-10-79$

$-11-79$
Location

$12 \mathrm{~N} \quad 44 \mathrm{E}$

5S $41 \mathrm{E}$

5S $4 I E$

5S $41 E$

$5 \mathrm{~S} \quad 41 \mathrm{E}$

5S $41 \mathrm{E}$

5S 4lE

5S 4 IE

5S $41 \mathrm{E}$

5S $41 \mathrm{E}$

5S $41 E$

5S $4 I E$

5S 4IE

5S $41 \mathrm{E}$

5S $4 I E$

5S $4 I E$

5S $41 \mathrm{E}$

5S 4 IE

5S $41 E$

5S $4 I E$

$5 S \quad 4 \mathrm{E}$

5S $41 \mathrm{E}$

6S $42 E$

6S $42 E$

$6 S \quad 42 E$

$6 \mathrm{~S} \cdot 42 \mathrm{E}$

6S $42 E$

6S $42 \mathrm{E}$

6S $41 \mathrm{E}$

6S $41 \mathrm{E}$

6S 4 IE

6S $41 E$

6S 4 IE

6S $4 I E$

6S 4IE

6S $41 E$

6S 4IE

6S $41 \mathrm{E}$

7S $4 \mathrm{IE}$

7S 4 IE

7S $41 \mathrm{E}$

7S $41 E$

7S 4 IE

7S $41 \mathrm{E}$

$7 \mathrm{~S} \quad 42 \mathrm{E}$

$7 S \quad 42 E$

$7 S \quad 42 \mathrm{E}$

$7 S \quad 42 E$

$7 S \quad 42 E$
Sec.

16

9

10

13

14

15

16

22

23

24

25

26

29

31

32

33

36

29

30

31

32

13

14

16

20

34

36

3

4

8

15

17

18

20

28

30

31

4

5

7

17

19

36

1

2

3

10

11
Acres County.

160

640

640

640

640

640

640

400

440

640

640

640

280

80

40

40

40

440

640

642

560

640

640

640

240

240

640

630

280

641

640

440

640

64.1

640

640

641

640

438

441

614

640

612

360

419

423

425

560

600
Fremont

Caribou

Caribou

Caribou

Caribou

Caribou

Caribou

Caribou

Caribou

Caribou

Caribou

Caribou

Caribou

Caribou

Caribou

Caribou

Caribou

Caribou

Caribou

Caribou

Caribou

Caribou

Caribou

Caribou

Caribou

Caribou

Caribou

Caribou

Caribou

Caribou

Caribou

Caribou

Caribou

Caribou

Caribou

Caribou

Caribou

Caribou

Caribou

Caribou

Caribou

Caribou

Caribou

Caribou

Caribou

Caribou

Caribou

Caribou 
SUPRON ENERGY CORP (cont.)

\begin{tabular}{rrrrr} 
Lease No. & Location & Sec & Acres & County \\
\hline $4027-12-79$ & $7 S 42 \mathrm{E}$ & 12 & 520 & Caribou \\
$-29-79$ & $7 S 42 \mathrm{E}$ & 29 & 640 & Caribou \\
$4463-16-79$ & $12 S 41 \mathrm{E}$ & 16 & 640 & Franklin \\
$4465-16-79$ & $12540 \mathrm{E}$ & 16 & 400 & Franklin \\
$-36-79$ & $12 S 40 \mathrm{E}$ & 36 & 200 & Franklin \\
$4647-16-79$ & $13 S 40 \mathrm{E}$ & 16 & 160 & Franklin \\
$-36-79$ & $13 S 40 \mathrm{E}$ & 36 & 400 & Franklin \\
$4649-16-79$ & $13 S 41 \mathrm{~S}$ & 16 & 200 & Franklin
\end{tabular}


UNION OII COMPANY OF CALIFORNIA

$46 I$ S. Boylston Street

Los Angeles, CA 90017

Total Acres 131,707

LEASE NO:

$$
\begin{array}{r}
2573-12-79 \\
-15-79 \\
-16-79 \\
-18-79 \\
-26-79 \\
-32-79 \\
-33-79 \\
-34-79 \\
-35-79
\end{array}
$$

$2573-36-79$

$2575-18-79$

$-31-79$

$-32-79$

$2589-07-79$

$-08-79$

$-17-79$

$-18-79$

2591-02-79

$-03-79$

$-04-79$

$-05-79$

$-06-79$

$-07-79$

$-08-79$

$-09-79$

$-10-79$

$-11-79$

$-12-79$

$-13-79$

$-14-79$

$-15-79$

$-16-79$

$-17-79$

$-18-79$

$-19-79$

$-20-79$

$-21-79$

$-22-79$

$-23-79$

$-24-79$

$-25-79$

$-26-79$

$-27-79$

$-28-79$

$-29-79$

$-30-79$

$-31-79$

$-32-79$

\section{LOCATION}

8N $42 E$

$8 \mathrm{~N} \quad 42 \mathrm{E}$

$8 \mathrm{~N} 42 \mathrm{E}$

$8 N \quad 42 E$

$8 N \quad 42 E$

$8 N \quad 42 E$

$8 \mathrm{~N} \quad 42 \mathrm{E}$

$8 \mathrm{~N} 42 \mathrm{E}$

$8 N \quad 42 E$

$8 N \quad 42 E$

$8 N \quad 43 E$

$8 N \quad 43 E$

$8 N \quad 43 E$

$7 N \quad 43 E$

$7 \mathrm{~N} \quad 43 \mathrm{E}$

$7 \mathrm{~N} \quad 43 \mathrm{E}$

$7 \mathrm{~N} \quad 43 \mathrm{E}$

$7 \mathrm{~N} \quad 42 \mathrm{E}$

$7 \mathrm{~N} \quad 42 \mathrm{E}$

$7 \mathrm{~N} .42 \mathrm{E}$

$7 \mathrm{~N} 42 \mathrm{E}$

$7 N \quad 42 E$

$7 \mathrm{~N} \quad 42 \mathrm{E}$

$7 \mathrm{~N} \quad 42 \mathrm{E}$

$7 N \quad 42 E$

$7 \mathrm{~N} \quad 42 \mathrm{E}$

$7 \mathrm{~N} \quad 42 \mathrm{E}$

$7 \mathrm{~N} \quad 42 \mathrm{E}$

$7 \mathrm{~N} \quad 42 \mathrm{E}$

$7 \mathrm{~N} \quad 42 \mathrm{E}$

$7 \mathrm{~N} \quad 42 \mathrm{E}$

$7 \mathrm{~N} \quad 42 \mathrm{E}$

$7 \mathrm{~N} \quad 42 \mathrm{E}$

$7 \mathrm{~N} \cdot 42 \mathrm{E}$

$7 \mathrm{~N} \quad 42 \mathrm{E}$

$7 N .42 E$

7N $42 \mathrm{E}$

$7 N \quad 42 E$

$7 \mathrm{~N} \quad 42 \mathrm{E}$

$7 N \quad 42 E$

$7 N \quad 42 E$

$7 N .42 E$

$7 \mathrm{~N}: 42 \mathrm{E}$

$7 \mathrm{~N} 42 \mathrm{E}$

$7 \mathrm{~N} \quad 42 \mathrm{E}$

$7 \mathrm{~N} \quad 42 \mathrm{E}$

$7 \mathrm{~N} 42 \mathrm{E}$

$7 \mathrm{~N} \quad 42 \mathrm{E}$
SECTION

12

15

16

18

26

32

33

34

35

36

18

31

$-32$

7

8

17

18

2

3

4
5

6

7

8

9
10

11

12

13

14

15

16

$17^{\circ}$

18

19

20

21

22

23

24

25

26

27

28

29

30

31

32
ACRES

160

160

160

139

160

240

480

480

440

240

158

80

40

322

320

520

482

563

644

644

400

624

627

640

640

640

640

240

400

440

480

600

640

629

471

520

340

409

247

480

217

329

640

640

160

197

280

640
COUNTY

Fremont

Fremont

Fremont

Fremont

Fremont

Fremont

Fremont

Fremont

Fremont

Fremont

Fremont

Fremont

Fremont

Fremont

Fremont

Fremont

Fremont

Eremont

Fremont

Fremont

Fremont

Fremont

Fremont

Fremont

Fremont

Fremont

Fremont

Fremont

Fremont

Fremont \& Madison

Fremont \& Madison

Fremont

Fremont

Fremont

Fremont \& Madison

Fremont \& Madison

Fremont \& Madison

Fremont \& Madison

Fremont \& Madison

Fremont \& Madison

Madison

Madison

Madison

Madison

Madison

Fremont \& Madison

Fremont \& Madison

Fremont \& Madison 
Union Oil Company of California (Continued)

LEASE NÓ.

$$
\begin{array}{r}
2591-33-79 \\
-34-79 \\
-35-79 \\
-36-79 \\
2593-01-79 \\
-10-79 \\
2593-11-79 \\
-12-79 \\
-13-79 \\
-24-79 \\
-25-79
\end{array}
$$

2777-01-79

$-9-79$

$-10-79$

$-11-79$

$-12-79$

$-13-79$

$-14-79$

$-15-79$

$-16-79$

$-21-79$

$-22-79$

$-23-79$

$-24-79$

$-25-79$

$-27-29$.

$-34 \div 79$

$-35-79$

$-36-79$

2779-01-79

$-02-79$

$-03-79$

$-04-79$

$-05-79$

$-06-79$

$-07-79$

$-08-79$

$-09-79$

$-10-79$

$-11-79$

$-12-79$

$-13-79$

$-14-79$

$-16-79$

$-17-79$

$-18-79$

$-19-79$

$-20-79$

$-21-79$

$-22-79$
LOCATION

$7 \mathrm{~N} 42 \mathrm{E}$

$7 \mathrm{~N} 42 \mathrm{E}$

$7 \mathrm{~N} .42 \mathrm{E}$

7 N. 42 E

$7 \mathrm{~N} .41 \mathrm{E}$

$7 \mathrm{~N} 41 \mathrm{E}$

$7 \mathrm{~N} 41 \mathrm{E}$

$7 \mathrm{~N} 4 \mathrm{IE}$

7N 4IE

7N 4 IE

$7 \mathrm{~N}$ 4IE

6N 4IE

6N 4IE

$6 \mathrm{~N} 41 \mathrm{E}$

6N 4IE

$6 \mathrm{~N} 41 \mathrm{E}$

$6 \mathrm{~N} \cdot 41 \mathrm{E}$

6N 4IE

$6 \mathrm{~N} 4 \mathrm{IE}$

$6 \mathrm{~N} 41 \mathrm{E}$

6N 4IE

$6 \mathrm{~N} 41 \mathrm{E}$

$6 \mathrm{~N} 41 \mathrm{E}$

$6 \mathrm{~N} 41 \mathrm{E}$

$6 \mathrm{~N} 4 \mathrm{IE}$

$6 \mathrm{~N} 4 \mathrm{IE}$

$6 \mathrm{~N} 41 \mathrm{E}$

$6 \mathrm{~N} 41 \mathrm{E}$

$6 \mathrm{~N} 4 \mathrm{IE}$

$6 \mathrm{~N} 42 \mathrm{E}$

$6 \mathrm{~N} \quad 42 \mathrm{E}$

$6 \mathrm{~N} 42 \mathrm{E}$

$6 \mathrm{~N} 42 \mathrm{E}$

$6 \mathrm{~N} 42 \mathrm{E}$

$6 \mathrm{~N} 42 \mathrm{E}$

$6 \mathrm{~N} 42 \mathrm{E}$

$6 \mathrm{~N} 42 \mathrm{E}$

$6 \mathrm{~N} 42 \mathrm{E}$

$6 \mathrm{~N} 42 \mathrm{E}$

$6 \mathrm{~N} 42 \mathrm{E}$

$6 \mathrm{~N} 42 \mathrm{E}$

$6 \mathrm{~N} 42 \mathrm{E}$

$6 \mathrm{~N} 42 \mathrm{E}$

$6 \mathrm{~N} 42 \mathrm{E}$

$6 \mathrm{~N} \quad 42 \mathrm{E}$

$6 \mathrm{~N} 42 \mathrm{E}$

$6 \mathrm{~N} 42 \mathrm{E}$

$6 \mathrm{~N} 42 \mathrm{E}$

6 N $42 E$

$6 \mathrm{~N} 42 \mathrm{E}$

\section{SECTION}

33

34

35

36

1

10

11

12

13

24

25

1

9

10

11

13

14

15

16

21

22

23

24

25

27

34

35

36

1

2

3

4

5

6

7

8

9

10

11

12

13

14

16

17

18

19

20

21

22
ACRES

COUNTY

280

640

453

333

320

80

360

640

320

440

160

80

160

160

480

640

640

640

640

480

40

64.0

640

640

320

320

240

440

640

272

641

441

401

200

160

560

640

320

160

320

360

40

40

600

640

639

520

160

160

480
Madison

Madison

Madison

Madison

Fremont

Fremont

Fremont

Fremont

Fremont

Fremont

Fremont

Madison

Madison

Madisoin

Madison

Madisón

Madison

Madison

Madison

Madison

Madison

Madison

Madisón

Madison

Madison

Madison

Madison

Madison

Madison

Madison

Madison

Madison

Madison

Madison

Madison

Madison

Madison

Madison

Madison

Madison

Madison

Madison

Madison

Mádison

Madison

Madison

Madison

Madison

Madison

Madison 
Union Oil Company of California (Continued)

LEASE NO.

$2779-23-79$

$-24-79$

$-25-79$

$-26-79$

$-27-79$

$-28-79$

$-29-79$

$-30-79$

$-31-79$

$-32-79$

$-33-79$

$-34-79$

$-35-79$

$-36-79$

2797-01-79

$-02-79$

$-03-79$

$-04-79$

$-05-79$

$-06-79$

$-07-79$

$-08-79$

$-09-79$

$-10-79$

$-11-79$

$-12-79$

$-13-79$

$-14-79$

$-15-79$

$-16-79$

$-17-79$

$-18-79$

$-19-79$

$-20-79$

$-21-79$

$-22-79$

$-23-79$

$-24-79$

$-26-79$

$-27-79$

$-28-79$

$-29-79$

$-30-79$

$-3.1-79$

$-32-79$

$-33-79$

$-34-79$

2799-01-79.

$-02-79$

$-05-79$

$-06-79$

$-07-79$
LOCATION

$6 \mathrm{~N} \quad 42 \mathrm{E}$

$6 \mathrm{~N} \quad 42 \mathrm{E}$

$6 \mathrm{~N} 42 \mathrm{E}$

$6 \mathrm{~N} \quad 42 \mathrm{E}$

$6 \mathrm{~N} \quad 42 \mathrm{E}$

$6 \mathrm{~N} \quad 42 \mathrm{E}$

$6 \mathrm{~N} \quad 42 \mathrm{E}$

$6 \mathrm{~N} .42 \mathrm{E}$

$6 N \quad 42 E$

$6 \mathrm{~N} \quad 42 \mathrm{E}$

$6 \mathrm{~N} \quad 42 \mathrm{E}$

$6 \mathrm{~N} \quad 42 \mathrm{E}$

$6 \mathrm{~N} \quad 42 \mathrm{E}$

$6 \mathrm{~N} \quad 42 \mathrm{E}$

$5 \mathrm{~N} \quad 42 \mathrm{E}$

$5 \mathrm{~N} \quad 42 \mathrm{E}$

$5 \mathrm{~N} 42 \mathrm{E}$

$5 \mathrm{~N} \quad 42 \mathrm{E}$

$5 \mathrm{~N} 42 \mathrm{E}$

$5 N \quad 42 E$

$5 \mathrm{~N} 42 \mathrm{E}$

$5 \mathrm{~N} \quad 42 \mathrm{E}$

$5 \mathrm{~N} 42 \mathrm{E}$

$5 \mathrm{~N} 42 \mathrm{E}$

$5 \mathrm{~N} \quad 42 \mathrm{E}$

$5 \mathrm{~N} 42 \mathrm{E}$

$5 \mathrm{~N} \quad 42 \mathrm{E}$

$5 \mathrm{~N} 42 \mathrm{E}$

$5 \mathrm{~N} 42 \mathrm{E}$

$5 \mathrm{~N}-42 \mathrm{E}$

$5 \mathrm{~N} 42 \mathrm{E}$

$5 \mathrm{~N} \quad 42 \mathrm{E}$

$5 \mathrm{~N} \quad 42 \mathrm{E}$

$5 \mathrm{~N} \quad 42 \mathrm{E}$

5N 42E

$5 \mathrm{~N} \quad 42 \mathrm{E}$

$5 \mathrm{~N} 42 \mathrm{E}$

$5 \mathrm{~N} 42 \mathrm{E}$

$5 \mathrm{~N} \quad 42 \mathrm{E}$

$5 \mathrm{~N} \quad 42 \mathrm{E}$

$5 \mathrm{~N} .42 \mathrm{E}$

$5 \mathrm{~N}: 42 \mathrm{E}$.

$5 \mathrm{~N} \quad 42 \mathrm{E}$

$5 \mathrm{~N} \quad 42 \mathrm{E}$

$5 \mathrm{~N} 42 \mathrm{E}$

$5 \mathrm{~N} \quad 42 \mathrm{E}$

$5 N \quad 42 E$

$5 N 4 I E$

$5 N \quad 41 E$

$5 \mathrm{~N} \quad 41 \mathrm{E}$

$5 N \quad 4 I E$

$5 \mathrm{~N} 41 \mathrm{E}$

\author{
SECTION
}

23

24

25

26

27

28

29

30

31

32

33

34

35

36

1

2

3

4

5

6

7

8

9

10

11

.12

13

14

15

16

17

18

19

20

21

22

23

24

26

27

28

29

30

31

32

33

34

1

2

5

6
ACRES

320

440

640

640

640

640

640

640

640

640

640

640

640

640

462

503

505

508

512

493

620

640

640

640

480

360

600

520

640

640

640

551

615

640

640

640

600

640

600

520

640

640

614

618

640

640

600

533

375

184

343

638
COUNTY

Madison

Madison

Madison

Madison

Madison

Madison

Madison

Madison

Madison

Madison

Madison

Madison

Madison

Madison

Madison

Madison

Madison

Madison

Madison

Madison

Madison

Madison

Madison

Madison

Madison

Madison

Madison

Madison

Madison

Madison

Madison

Madison

Madison

Madison

Madison

Madison

Madison

Madison

Madison

Madison

Madison

Madison

Madison

Madison

Madison

Madison

Madison

Madison

Madison

Madison

Madison

Madison 
Union Oil Company of California (Continued)

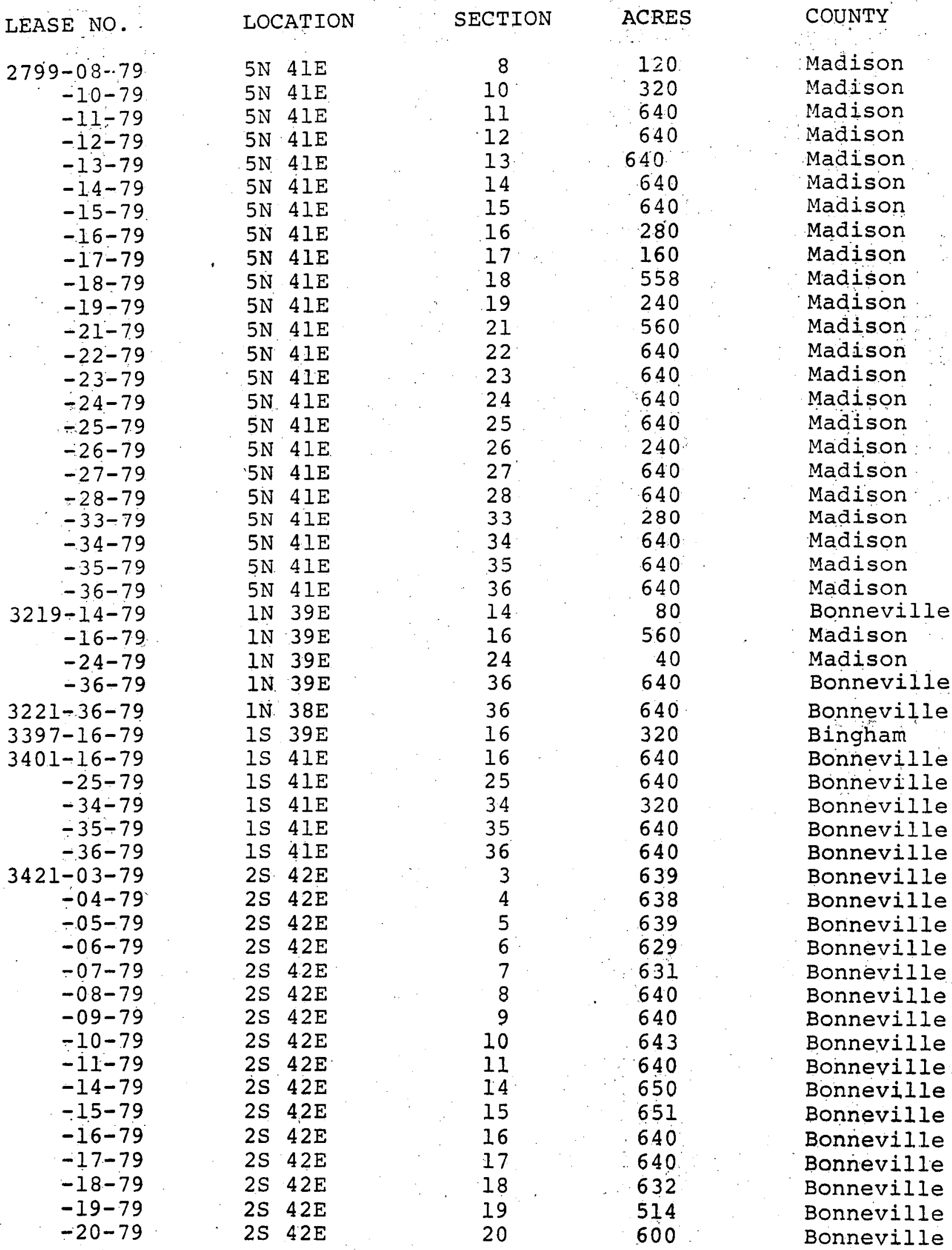


Union Oil Company of California (Continued)

LEASE NO.

$$
\begin{array}{r}
3421-21-79 \\
-22-79 \\
-23-79 \\
-24-79 \\
-25-79 \\
-26-79 \\
-27-79 \\
-28-79 \\
-29-79 \\
-30-79 \\
-31-79 \\
-32-79 \\
-33-79 \\
-34-79 \\
-35-79 \\
-36-79
\end{array}
$$$$
3423-01-79
$$$$
-02-79
$$$$
-03-79
$$$$
-04-79
$$$$
-05-79
$$$$
-08-79
$$$$
-09-79
$$$$
-11-79
$$$$
-12-79
$$$$
-13-79
$$$$
-15-79
$$$$
-16-79
$$$$
-17-79
$$$$
-19-79
$$$$
-20-79
$$$$
-21-79
$$$$
-22-79
$$$$
-23-79
$$$$
-24-79
$$$$
-25-79
$$$$
-26-79
$$$$
-27-79
$$$$
-28-79
$$$$
-29-79
$$$$
-30-79
$$$$
-32-79
$$$$
-33-79
$$$$
-34-79
$$$$
-35-79
$$$$
-36-79
$$$$
4675-16-79
$$$$
4677-10-79
$$$$
-15-79
$$

$$
\text { LOCATION }
$$

2S $42 \mathrm{E}$

2S $42 \mathrm{E}$

2S $42 \mathrm{E}$

2S $42 \mathrm{E}$

2S $42 \mathrm{E}$

2S $42 \mathrm{E}$

2S $42 \mathrm{E}$

2S $42 \mathrm{E}$

2S $42 \mathrm{E}$

2S $42 \mathrm{E}$

2S $42 \mathrm{E}$

2S $42 E$

2S $42 E$

2S $42 \mathrm{E}$

2S $42 \mathrm{E}$

2S $42 \mathrm{E}$

2S $41 \mathrm{E}$

2S $4 I E$

2S $41 E$

2S $41 \mathrm{E}$

2S $4 I E$

2S $41 \mathrm{E}$

2S $41 E$

2S $4 I E$

2S $41 E$

2S $41 \mathrm{E}$

2S $4 I E$

2S $41 E$

2S 4 IE

2S $41 E$

2S $41 E$

2S $41 E$

2S $41 \mathrm{E}$

2S $41 E$

2S $41 \mathrm{E}$

2S $41 E$

2S $41 \mathrm{E}$

2S $41 \mathrm{E}$

2S $41 \mathrm{E}$

2S $41 E$

2S $4 I E$

2S $41 \mathrm{E}$

2S $4 I E$

2S $4 I E$

2S $4 I E$

2S $41 \mathrm{E}$

$14 \mathrm{~S} 39 \mathrm{E}$

$14 \mathrm{~S} 38 \mathrm{E}$

$14 \mathrm{~S} 38 \mathrm{E}$

\section{SECTION}

21

22

23

24

25

26

27

28

29

30

31

32

33

34

35

36

1

2

3

4

5

8

11

12

13

15

16

17

19

20

21

22

23

24

25

26

27

28

29

30

32

33

34

35

36

16

10 .

15
ACRES

600

640

640

640

640

560

400

200

320

631

592

480

560

600

520

640

665

346

454

349

48

120

360

640

604

322

120

640

200

440

200

280

160

80

405

80

320

360

320

640

27

120

400

520

120

644

640

205

120
COUNTY

Bonneville

Bonnevilie

Bonneville

Bonnevilie

Bonneville

Bonneville

Bonneville

Bonneville

Bonneville

Bonneville

Bonneville

Bonneville

Bonnevilie

Bonneville

Bonneville

Bonneville

Bingham

Bingham

Bingham

Bingham

Bingham

Bingham

Bingham

Bingham

Bingham

Bingham

Bingham

Bingham

Bingham

Bingham

Bingham

Bingham

Bingham

Bingham

Bingham

Bingham

Bingham

Bingham

Bingham

Bingham

Bingham

Bingham

Bingham

Bingham

Bingham

Bingham

Franklin

Franklin

Franklin 
Federal Geothermal leases information comes from the serial Register Pages of Geothermal leasing in Idaho, as maintained by the BLM. The information is presented by lessee, and gives the lease number, date of issue, the location (resolution of one section), acreage and county. This list covers leases east of R. 20.E. only.

L.H. Armour, Jr.

Room 1940, 135 So. Lasalle st.

Total Acres:

Chicago; Illinois 60603

1480.0

$\begin{array}{lll}\text { LEASE NO. DATE ISSUED } & \frac{\text { LOCATION }}{\text { I }-7673} \\ 9-1-76 & \text { T5S R27E } \\ & & \text { SEC } 15,20,27\end{array}$

Delta Funds, Inc.

1401 Walnut street

Philadelphia, PA 19102

LEASE NO. DATE ISSUED IOCATION

$I-9513$

$10-1-76$

Lease Term. $10-1-78$

$I-9514$

$10-1-76$

Lease Term. 10-1-78

$\mathrm{I}-9515$

$10-1-76$

Lease Term. $10-1-78$

$I-9516$

$10-1-76$

Lease Term.

$10-1-78$
T15S R27E

Sec. $12,24,34$

T14S R27E

Sec. $10,11,15$

T16S R27E

Sec. $19,22,28$

29,30

T16S R26E

Sec. 24,30
ACREAGE

1480

COUNTY

Cassia
Total Acres:

5762.0

ACREAGE

COUNTY

1520

Cassia

1920

Cassia

1360.66

Cassia

961.25

Cassia

Pacific Energy Corporation

P.O. Box 1287

Ratchez, MS 39120

Total Acres:

2,560

LOCATION

ACREAGE

COUNTY

T2S, R44E,

Sec. $13,24,25,36$

$2,560.0$

Bonneville 
Phillips Petroleum Company

Geothermal Operations

P.O. Box 239

Salt Lake City, UT 84110

LEASE NO. DATE ISSUED LOCATION

I-7792 $7-1-78$ T14S, R26E,
Total Acres: $20,366.6$

Less Termination Net Acres $\frac{3,080 \cdot 9}{17,285.7}$ Sec. $1,2,11$

$\begin{array}{ll}\text { ACREAGE } & \text { COUNTY } \\ 1,600.68 & \text { Cassia }\end{array}$

Total Acres: 1883.1

Box 617

Malta, ID 83342

LEASE NO. DATE ISSUED LOCATION

ACREAGE $\quad$ COUNTY

$I-14166$ (a)

4-1-78 KGRA T15S, R26E,

Sec. $14,15,21,28$,

29,32

$1,883.1$

Cassia

(a) Competition Bid Lease Sale - KGRA - Raft River

Sunoco Energy Development Co.

Total Acres:

12700 Park Central Place

Suite 1500

Dallas, Texas 75251

\begin{tabular}{|c|c|c|c|c|}
\hline LEASE NO. & DATE ISSUED & LOCATION & ACREAGE & COUNTY \\
\hline-7617 & $7-1-75$ & $\begin{array}{l}\text { T14S, R27E, } \\
\text { Sec. } 25\end{array}$ & 640 & Cassia \\
\hline$I-7633$ & $12-1-76$ & $\begin{array}{l}\text { T14S, R26E, } \\
\text { Sec. } 31,32 \\
\text { T15S, R26E, Sec. } 5\end{array}$ & $1,777.55$ & Cassia \\
\hline$I-7.634$ & $2-1-78$ & $\begin{array}{l}\text { T15S, R26E, } \\
\text { Sec. } 20,21,29\end{array}$ & $1,441.93$ & Cassia \\
\hline$I-7660$ & $\begin{array}{l}12-1-76 \\
\end{array}$ & $\begin{array}{l}\text { T16S, R.26E, } \\
\text { Sec. } 8,9,17,20\end{array}$ & 1,680 & Cassia \\
\hline$I-7702$ & $8-1-75$ & $\begin{array}{l}\text { TI4S, R27E, } \\
\text { Sec. } 21,28\end{array}$ & 800 & Cassia \\
\hline$I-7710$ & $10-1-77$ & $\begin{array}{l}\text { T16S, } R 26 \mathrm{E}, \\
\text { Sec. } 3,10,15\end{array}$ & $1,713.74$ & Cassia \\
\hline$I-7720$ & $5-1-76$ & $\begin{array}{l}\text { T13S, R26E, } \\
\text { Sec. } 25\end{array}$ & 240 & Cassia \\
\hline
\end{tabular}


Sunoco Energy Development Co. (Continued)

LEASE NO. DATE ISSUED LOCATION

I-7781 7-1-75

Lease Term.

$7-1-79$

I-7802 7-1-75

Lease Term.

7-1-79

I-7844 7-1-75

Lease Term.

$7-1-79$

I-9376 9-1-76

I-9377. 9-1-76

E.J. Wilson \& Sons

Lidy Hot Springs

Star Route

Dubois, ID 83423

LEASE NO. DATE ISSUED

I-7949 10-1-77
T13S, R27E,

Sec. $25,26,35$

T14S, R27E,

Sec. 26,35

TI5S, R27E

Sec. 35

T16S, R27E, ,

Sec. $1,2,11$

T16S, R27E,

Sec. $5,6,7,8,18$

T1.6S, R28E,

Sec. 5,7
ACREAGE COUNTY

1,920. Cassia

1,280 Cassia

1,501.72 Cassia

1,708.8 Cassia

481.29 Cassia

Total Acres:

$1,246.4$

ACREAGE $\quad$ COUNTY

1,246.44 Clark 


\section{STATE OIL AND GAS LEASE ACREAGE BY LESSEE East of R. 20 E.}

This information is a summation of lease acreage by lessee, from the index file of State $\mathrm{Oil}$ and Gas Leases as maintained by the Idaho Department of Lands (specific location information is available from the Idaho Department of Lands and the Idaho Office of Energy). This list only covers leases east of R. $20 \mathrm{E}$.

Lessee

A A Minerals

Allied Chemical

American Quasar Petroleum of New Mexico

Amoco Production Co.

Donald B. Anderson

Ida Lee Anderson

The Anschutz Co.

Arkla Exploration Co.

Chevron USA, Inc.

Cities Service Co.

Conoco

Croff Oil Co.

Crown Central Petroleum

Raymond T. Duncan

Vincent $J$. Duncan

Energy Reserves Group, Inc.

Enserch Exploration, Inc.

Filon Exploration Corp.
$100 \%$ Ownership Lease Acreage

360

320

$75 \%$

$3,186.83$

4,676

$50 \%$

$37.5 \%$

$44,851.39$

$27,883.72$

$30,963.04$

14,576

14,366

$50 \%$

65,051

50 응

$8,511.68$

$1,227.06$

55,159

$75 \%$

2,306

$39,220.55$

20,193

$25 \%$

42,357

2,931

40

Acreage 
100\% Ownership Lease Acreage

Martin Freedman and Robert Haynie

General American Oil Co. of Texas

W.A. Giliespie

W. R. Grace

Gulf Oil Corp.

Hamilton Bros. OiI

Joanna D. Hoefle

Richarä C. Hoefle

Hunt Energy Corp.

Hunt Petroleum Co.

IGC Production

Impel Corp.

Lewis H. Larson

Louisiana Land

Burt $G$. Lowe

William S. Marshall

Marshal1 and Winston

Martin Oil Service, Inc.

Mày Petroleum

Len Mayer

Mobil Oil Corp.

Narméo

National Refinery Cooperative Association

Nátural Resources
2,483

640
3,430

2,246

$103,640.36$

34,783

$1,841.5$

14,880

2,560

$23,047.25$

130

320

40

14,712

8,640

26,655
Joint Ownership Leases

Percentage Acreage

$54.1 \%$

1,320

$25 \%$

$3,506.83$

$5 \%$

5,374

$40 \%$

5,040

$50 \%$

22,694

$25 \%$

42,357

$50 \%$

31,443 
Frank J. Novosel

Odessa Natural Corp.

Pacific Transmission Supply Company

Patrick Petroleum Corp. of Michigan

2,413

5,395

$50 \%$

$50 \%$

$50 \%$

$43,922.41$

Phillips Petroleum

Reading \& Bates Petroleum Company

26,751

Reserve Oil, Inc.

15,808

Dean R. Rogers

Norma Rose

Sanchez-0'Brien Petroleum Group 1,080

Shell Oil Co.

61,191

Robert Smith

4,218

Sohio Petroleum

5,826

$50 \%$

25 응

4,802

$5,304.2$

$8,511.68$

Howell spear

5,826

William A. Stevenson

12,560

Sumatra Oil Co.

$45.9 \%$

1,320

Sun oil Co.

3,840

$50 \%$

620

$37.5 \%$

$12.5 \%$

320

$27,883.72$

Supron Energy Corp.

1,879

$50 \%$

$37.5 \%$

620

320

$12.5 \%$

$27,883.72$

David A. Swenson

21,138

Tucker \& Snyder Exploration

$20 \%$

5,040

Union Oil of California

4,600 
Lessee

Webb Resources

Western Reserves Oil

Clayton W. Williams, Jr.

Win-Mar Development

James K. Wollard

Delores Yates
$100 \%$ Ownership Lease Acreage

84,173

9,310

6,222

$5 \%$

5,374

$75 ㅇ ㅜ ㅇ$

920

$40 \%$

10,418
Joint Ownership Leases

Percentage Acreage

25

1,700

Total State Lease

Acres

East of R. 20 E.

$1,048,558.05$ 
FEDERAL OIL \& GAS LEASE ACREAGE BY LESSEE EAST OF R. 20 E.

Federal oil and gas lease information comes from the Serial Register Pages of Oil and Gas Leases in Idaho maintained by the BLM. This list is a summation of total acreage under lease by lessee in that portion of Idaho east of R. $20 \mathrm{E}$. (Information as to specific locations of an individual lease is available from the BLM and the Idaho Office of Energy).

\section{Lessee}

Adobe Oil \& Gas Corp.

Amoco Production Co.

American Petrofino Co.

American Quasar Petroleum of New Mexico

American Quasar Petroleum of New Mexico et al

Anderson, Donald B. Ltd. et al

Andregg, Kathy

Anschutz Corp. et al

Bloom, J.W.

Campbell, Graham S.

Chevron USA, Inc.

Cities Service co.

Continental Oil Co.

Crest Resources, Inc.

Croff Oil Co.

David, Robert $W$.

Dever, Dolores $A$.

Double Eagle Petroleum \& Mining Co.

Duncan, Vincent $J$.
Total Acreage

$$
3,284.42
$$

$72,398.68$

$48,251.18$

$6,800.82$

$53,662.58$

$215,357.37$

$4,210.53$

$23,796.49$

$2,103.04$

$13,918.6$

$21,940.23$

$64,512.16$

$32,290.15$

$1,928.98$

$8,453.34$

1,007

525.8

80

160 
Table 8 Continued

\section{Lessee}

Edwards, Carolyn S.

Edwards, Stanley M.

EIf Aquitaine, Inc.

General American Oil Co.

Grace Petroleum Corp. et al

Gulf Oil Corp. et al

Hamilton Brothers Oil Co. et al

Hartley, Esdras

Haun, W.G.

Hoefle, R.C.

Hoefle, R.C. et al

Hunt Energy Corp.

Hunt Nelson Bunker Trust Estate et al

IGC Production

Impel Energy Coxp. et al

Intermountain Gas Co.

Larson, Lewis $H$.

Lasrich, Beverley

Louisiana Land \& Exploration Co.

Maddox, Bil J.

Maddox, Ruth

Maddox, Verba:

Madrid, Louis $\mathbf{S}$.

Marshall \& Winston, Inc. et al
Total Acreage

5,127

$24,571.9$

$8,479.80$

$21,590.64$

$44,680.02$

$65,664.54$

$8,921.35$

$1,788.91$

2,560

$89,934.13$

$142,364.87$

$15,357.88$

$50,408.38$

$3,230.86$

$15,730.01$

$3,260.14$

$37,330.5$

200

$182,879.95$

$6,383.05$

$3,434.12$

$1,737.6$

680

6.823 .00 
Table 8 Continued

Lessee

Martin Exploration Management Corp.

Mayer, Len

Mayer, Len et al

May Petroleum Co.

Meinhart, Arthur E.

Mitchell Energy Corp.

Mobile Oil

Moore, W.V.

Mountain Fuel Supply Co.

Natural Resources Corp.

Natural Resources Corp. et al

Notestine, Tom

Novosel, Patricia Y.

Odessa Natural Corp.

Pacific Transmission Supply co. et al

Patrick Petroleum Corp. et al

Phillips Petroleum Co.

Potts, Martha I.

Potts, Neal H.

Reading \& Bztes Petroleum Co.

Richey, Mark W.

Rogers, Dean R. Jr.

Sanchez O'Brian Petroleum Group

Scott, Charles $w$.

shell Oil Co.

\section{Total Acreage}

$2,475.4$

$29,420.13$

$51,408.05$

12,155

1,930

240

$144,759.98$

1,280

3.75

$79,997.68$

$21,543.87$

40

2,520

$158,134.23$

$50,226.37$

$123,622.05$

$119,670.11$

$4,318.99$

640

$16,141.6$

2,483

$11,495.47$

$22,794.98$

2,300

$237,783.55$ 
Table 8 Continued

Lessee

Silane, Floyd E.

Smith, Robert $W$.

Smith, Robert w. et a.l

Sohio Natural Resources Co.

Spangler, Laura J.

Spear, Howell

Stevenson, William A.

Stoltz, Wagner, \& Brown et al

Sun Oil Co. et al

Supron Enrgy Corp.

Supron Energy Corp. et al

Taft, Milford

Texas Pacific Oll Co., Inc.

Tiperary OiI \& Gas Co.

Toltec Drilling Co.

Transocean Oil, Inc.

Trujillo, Rosita

Tucker \& Snyder Exploration, Inc.

Webb: Resources, Inc.

Webb Resources, Inc. et al

Western Reserves Oil Co.

Wilson, Earl R. et al

Wolter, George P., Jr.

\section{Total Acreace}

640

$5,494.48$

$2,372.46$

26.5

$7,358.32$

7.897 .24

$3,814.96$

$125,141.87$

$159,410.21$

$14,985.35$

$33,059.06$

$9,181.9$

$76,993.0$

$1,899.25$

$54,725.94$

$119,124.81$

$6,558.2$

370

$51,251.13$

$41,501.17$

$2,499.37$

$7,454.22$

799.59 
TABLE 9

OLL AND GAS EXPLORATON WELIS IN EASTERE IDAHO

(EAST OF R.2OE., B.H.)

\begin{tabular}{|c|c|c|c|c|c|c|c|c|c|}
\hline TOWns & SHTP & SEC. & COMPANY & WHIL NAME & 1)ATE & DE:'lH & LOGS & Cous:ir & RENARKS \\
\hline $114 \mathrm{~N}$ & $\mathrm{R} 36 \mathrm{E}$ & 32 & $\begin{array}{l}\text { Mondia Oil Co. } \\
\text { Fred G. Ostland }\end{array}$ & Rose \#1 & 1926 & 1385 & No & & Abandoned. \\
\hline $\mathrm{T} 6 \mathrm{~N}$ & R31E & 27 & U.S.G.S. & & & 774 & & Butte & $\begin{array}{l}\text { USGS; dry } \\
\text { water. }\end{array}$ \\
\hline $\mathrm{T} 6 \mathrm{~N}$ & $R 44 E$ & 35 & Fremont oil co. & & 1.903 & 660 & No & Tetor: & Abandoned. \\
\hline T5N & $\mathrm{R} 44 \mathrm{E}$ & 26 & $\begin{array}{l}\text { Am. Quasar } \\
\text { Petro. of N.M. }\end{array}$ & Cook 26-1 & $\begin{array}{l}10-77 \text { to } \\
2-78\end{array}$ & 6565 & $\begin{array}{l}\text { P\& A: DL, } \\
\text { BHC-soniC, } \\
\text { CFI, FDC.CHI., } \\
\text { DIL-SFL-E, ITI, } \\
\text { HRT }\end{array}$ & leton & $\begin{array}{l}\text { Plugged and } \\
\text { abandoned. }\end{array}$ \\
\hline $7.5 \mathrm{~N}$ & R44E & 26 & $\begin{array}{l}\text { Ari: Quasar } \\
\text { Petro of N.M. }\end{array}$ & State 26-1 & & & & Teton & $\begin{array}{l}\text { Permit } 3-14-78 \text { : } \\
\text { not drilled. }\end{array}$ \\
\hline $15 \mathrm{~N}$ & $R^{\prime}+4 E$ & 28 & $\begin{array}{l}\text { Teton Valley } \\
\text { I. \& L Co. }\end{array}$ & H 1 & 1926 & 1300 & No & Teton & Abandoned. \\
\hline TSiN & $\mathrm{R} 44 \mathrm{E}$ & 28 & $\begin{array}{l}\text { Teton Valley } \\
\text { L \& I. Co. }\end{array}$ & Bovan & 1.926 & 1392 & No & jet:s: & Abandoned. \\
\hline TSN & $\mathrm{R} 44 \mathrm{E}$ & 28 & $\begin{array}{l}\text { Phillips Petrol. } \\
\text { Co. }\end{array}$ & Horshoe it & $\begin{array}{l}9-51 \text { to } \\
3-53\end{array}$ & 12720 & Lithologic & Tetan & \\
\hline $\mathrm{T} 5 \mathrm{~N}$ & $\mathrm{R} 44 \mathrm{E}$ & 28 & $\begin{array}{l}\text { Sun Production } \\
\text { Co. } \\
2525 \text { N.W. Expw. }\end{array}$ & $1-28$ & & & & Telli: & $\begin{array}{l}\text { Permit } 4-17-78 \text {; } \\
\text { not drilled. }\end{array}$ \\
\hline
\end{tabular}




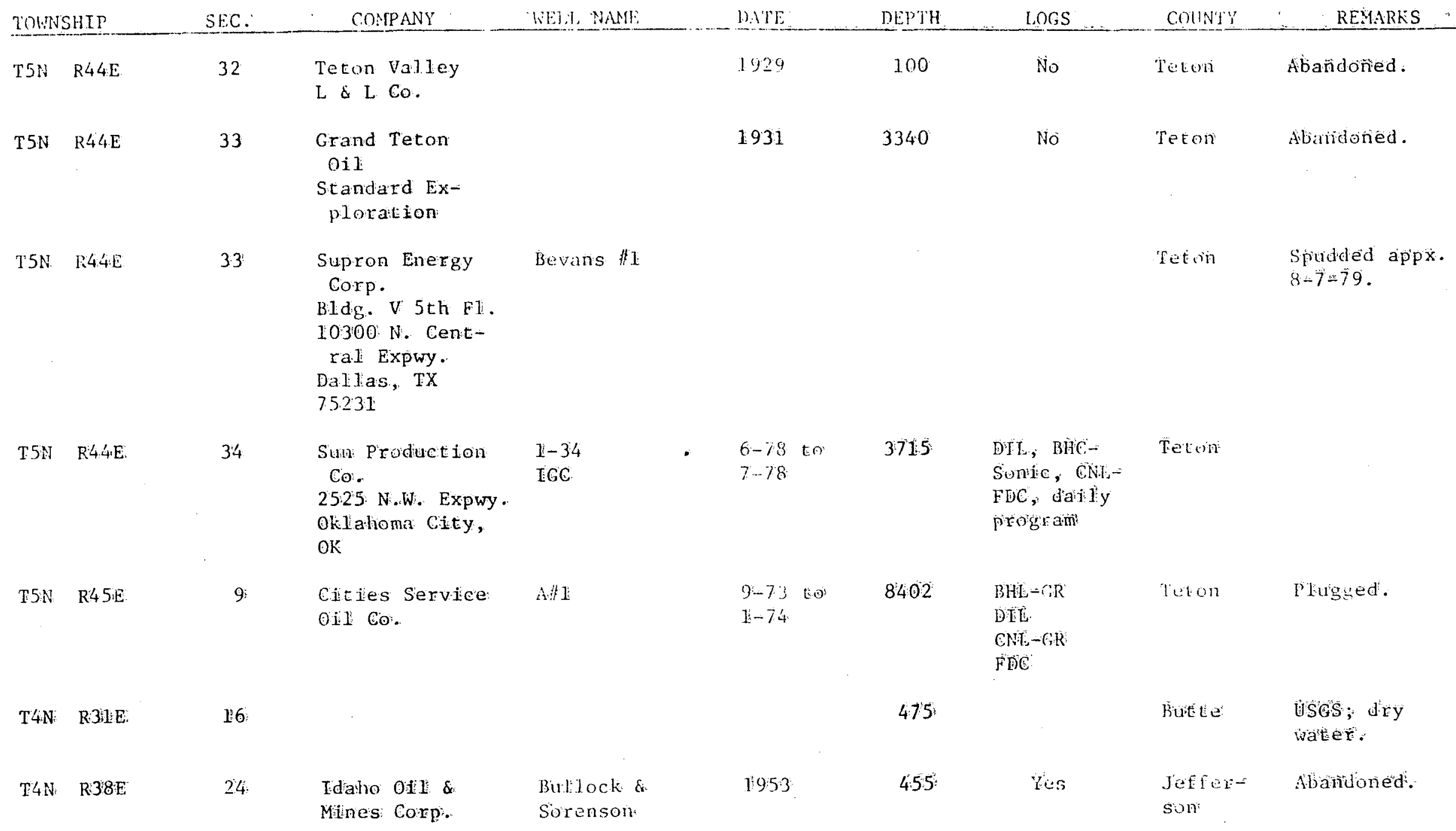




\begin{tabular}{|c|c|c|c|c|c|c|c|c|c|}
\hline TOWN & SHIP. & SEC. & COMPANY & WELL NAME & DATE & DEPTH & LOGS & COUNTY & REMARKS \\
\hline $\mathrm{T} 3 \mathrm{~N}$ & R29E & 14 & & & & 547 & & Butte & $\begin{array}{l}\text { USGS; dry } \\
\text { water. }\end{array}$ \\
\hline $\mathrm{T} 3 \mathrm{~N}$ & $\mathrm{R} 30 \mathrm{E}$ & 12 & & & & 499 & & Butte & $\begin{array}{l}\text { USGS; dry } \\
\text { water. }\end{array}$ \\
\hline $\mathrm{T} 3 \mathrm{~N}$ & $\mathrm{R} 32 \mathrm{E}$ & 29 & & & & 698 & & Butte & $\begin{array}{l}\text { USGS; dry } \\
\text { water. }\end{array}$ \\
\hline $\mathrm{T} 3 \mathrm{~N}$ & $\mathrm{R} 41 \mathrm{E}$ & 33 & $\begin{array}{l}\text { California } \\
\text { Company }\end{array}$ & Sorensen \#1 & $\begin{array}{l}1928- \\
1930\end{array}$ & 3774 & Yes & $\begin{array}{l}\text { Bonite- } \\
\text { ville }\end{array}$ & $\begin{array}{l}\text { Abandoned; show } \\
\text { ing of asphalti: } \\
\text { material re- } \\
\text { ported, not con- } \\
\text { firmed by log. }\end{array}$ \\
\hline $\mathrm{T} 2 \mathrm{~N}$ & R31E & 35 & & Arco $T$ & & 635 & Well log: & Bingugam & USGS water. \\
\hline $\mathrm{T} 1 \mathrm{~N}$ & $\mathrm{R} 44 \mathrm{E}$ & 24 & Edwin Allday & $\# 1$ & $\begin{array}{l}9-65 \text { to } \\
2-66\end{array}$ & 5760 & $\begin{array}{l}\text { Mud, daily } \\
\text { rpt., eléc- } \\
\text { tric, DSf's }\end{array}$ & $\begin{array}{l}\text { Bonne- } \\
\text { ville }\end{array}$ & Abandoned. \\
\hline T1S & R39E & 8 & $\begin{array}{l}\text { Union Oil Co. } \\
\text { of California } \\
\text { Box } 2620 \\
\text { Casper, Wy } \\
82602\end{array}$ & HOEE $1-8:-1$ & $\begin{array}{l}5-79 \text { to } \\
9-79\end{array}$ & $8930^{\circ}$ & No & Eingham & \\
\hline $\mathrm{T} 2 \mathrm{~S}$ & $\mathrm{R} 4 \mathrm{LE}$ & 2 & $\begin{array}{l}\text { Am. Quasar Petro } \\
\text { of N.M. } \\
330 \text { Pacific Wes- } \\
\text { tern Bldg. } \\
\text { Casper, WY } \\
82601\end{array}$ & King $2-1$ & $\begin{array}{l}2-78 \text { co } \\
3-78\end{array}$ & 13555 & $\begin{array}{l}\text { P\&d, FDC- } \\
\text { CNL-GR; BHC- } \\
\text { GR; DIL-SFI; } \\
\text { l-ESS DLT-GR; } \\
\text { Cyberlook; } \\
\text { Daily log; } \\
\text { Geo Rot; Geo- } \\
\text { log; } 9 \text { DSI's }\end{array}$ & bingliara & $\begin{array}{l}\text { Plugged and } \\
\text { abandoned. }\end{array}$ \\
\hline
\end{tabular}




\begin{tabular}{|c|c|c|c|c|c|c|c|c|c|}
\hline TOWN & HIP & SEC... & COMPANY & WELL . NAMT: & DATE & - DEPTH & LOGS & COUNTY & $\therefore$ REMARKS \\
\hline $\mathrm{T} 2 \mathrm{~S}$ & $\ddot{R} 44 \mathrm{E}$ & 23 & $\begin{array}{l}\text { Sun-Sinclair } \\
\text { (Sun Oil Co.) }\end{array}$ & $\begin{array}{l}\text { Big Elk Mtn. } \\
\# 1\end{array}$ & $\begin{array}{l}2-49 \text { to } \\
10-50\end{array}$ & 5597 & Yes & $\begin{array}{l}\text { honne- } \\
\text { ville }\end{array}$ & $\begin{array}{l}\text { Abandoned; dry } \\
\text { hole partly } \\
\text { drilled, partly } \\
\text { cored, lost nud }\end{array}$ \\
\hline $\mathrm{T} 2 \mathrm{~S}$ & $\mathrm{R} 44 \mathrm{E}$ & 24 & Pan American & T. J. Weber & $\begin{array}{l}9-63 \text { to } \\
10-64\end{array}$ & 9717 & Yes & $\begin{array}{l}\text { Bonlle- } \\
\text { ville }\end{array}$ & Abandoned. \\
\hline $\mathrm{T} 3 \mathrm{~S}$ & $\mathrm{R} 45 \mathrm{E}$ & 36 & $\begin{array}{l}\text { Am. Quasar Petro } \\
\text { of N.M. }\end{array}$ & $\# 1$ & $\begin{array}{l}8-76 \text { to } \\
2-77\end{array}$ & 14330 & $\begin{array}{l}\text { DLL, DIL; } \\
\text { BHC-GR, DST } \\
(4) \\
\mathrm{H}_{2} \mathrm{O} \text { Analysis } \\
\text { Ceinent }\end{array}$ & $\begin{array}{l}\text { Bonue- } \\
\text { ville }\end{array}$ & $\begin{array}{l}\text { Plugged and } \\
\text { abandoned. }\end{array}$ \\
\hline T4S & $\mathrm{R} 42 \mathrm{E}$ & 9 & $\begin{array}{l}\text { Continental oil } \\
\text { Co. } \\
152 \mathrm{~N} \text {. Durbin } \\
\text { Casper, WY } \\
82601\end{array}$ & $\begin{array}{l}\text { Gentle Valley } \\
\text { \#1 }\end{array}$ & $\begin{array}{l}9-78 \text { to } \\
12-78\end{array}$ & 9913 & Yes* & $\begin{array}{l}\text { Bonne- } \\
\text { ville }\end{array}$ & $\begin{array}{l}\text { *Cyterlook (3), } \\
\text { DLL-RXO, DIL (3 } \\
\text { FDC/CNL (3), BL } \\
\text { GR (4), HDT (4) } \\
\text { HRT (3), CDR (- } \\
\text { Cement (1). }\end{array}$ \\
\hline T7S & $\mathrm{R} 44 \mathrm{E}$ & 32 & $\begin{array}{l}\text { Standard oil } \\
\text { of California }\end{array}$ & Dry Valley & $\begin{array}{l}7-52 \text { co } \\
1.1-52\end{array}$ & 7868 & Hydrocarbon & Caribou & Abandoned. \\
\hline TyS & $R 46 \mathrm{E}$ & 34 & $\begin{array}{l}\text { Wa } 11 \text { ace Wyoming } \\
\& \text { Great Western } \\
\text { Oil Co. }\end{array}$ & $\| 1$ & 1926 & 2448 & Hydrocarbon & Caribou & $\begin{array}{l}\text { Much salt } \\
\text { probably jur- } \\
\text { assic. }\end{array}$ \\
\hline T9S & R3OE & 35 & $\begin{array}{l}\text { Rockland Valley } \\
\text { oil }\end{array}$ & & 1926 & 1550 & No & Power & Abandoned. \\
\hline T9S & R42E & 27 & & $\begin{array}{l}\text { Frazier 非] } \\
\text { Ira Ellis }\end{array}$ & 1956 & 3540 & No & Caribou & $\begin{array}{l}\text { See AAPG Sym- } \\
\text { posium Vol. I- } \\
\text { memoir } 15 \mathrm{P} \text {. } \\
526-7 \\
0 \& \text { G shows. }\end{array}$ \\
\hline
\end{tabular}




\begin{tabular}{|c|c|c|c|c|c|c|c|c|}
\hline TOUNSHIP & SEC. & CONIPANY & WELL NAME & DATE & DEPTH & LOGS & conenty & REMARKS \\
\hline TIOS R33E & 35 & States Oil Co. & $\# 1$ & $7-69$ & 3680 & Yes & Power & Plugged. \\
\hline TIOS R36E & 14 & $\begin{array}{l}\text { Cache Gas \& } \\
\text { Oil Co. }\end{array}$ & Ashlette $\| 1$ & $\begin{array}{l}9-58 \text { to } \\
10-58\end{array}$ & 3003 & Hydrocarbon & Bannuck & Abandoned. \\
\hline TIOS R37E & 19 & $\begin{array}{l}\text { Norton Oil\& } \\
\text { Gas }\end{array}$ & $\# 1$ & 1927 & 1349 & Hydrocarbon & Bannock & $\begin{array}{l}\text { Minor gas and } \\
\text { oil show. }\end{array}$ \\
\hline TIOS R37E & 19 & $\begin{array}{l}\text { Norton Oil \& } \\
\text { Gas }\end{array}$ & $\# 2$ & & 2700 & Hydrocarbm & Bannock & $\begin{array}{l}\text { Minor gas and } \\
\text { oil show. }\end{array}$ \\
\hline T1OS R43E & 13 & $\begin{array}{l}\text { Union Texas } \\
\text { Petroleum } \\
1010 \text { Lincoln } \\
\text { Tower } \\
\text { Denver, co } \\
80295\end{array}$ & $\begin{array}{l}\text { Big Canyon } \\
\text { Federal } 1-13\end{array}$ & $\begin{array}{l}y-12-78 \\
\text { to } \\
3-4-79\end{array}$ & 11734 & Yes* & $\begin{array}{l}\text { bear } \\
\text { Lake }\end{array}$ & $\begin{array}{l}\text { DIL; FDC/CNL/ } \\
\text { GR; cyberlook; } \\
\text { BHC/GR; GR- } \\
\text { Casing Collar; } \\
\text { DLL; Log Ana- } \\
\text { lysis; hydro- } \\
\text { cisrbon. }\end{array}$ \\
\hline TIOS R43E & 21 & $\begin{array}{l}\text { Eastern Idaho } \\
\text { Development }\end{array}$ & State & $\begin{array}{l}5-56 \text { to } \\
5-56\end{array}$ & 3900 & Hydrocarbon & $\begin{array}{l}\text { Bear } \\
\text { Luke }\end{array}$ & $\begin{array}{l}\text { Abandoned; dry } \\
\text { hole. }\end{array}$ \\
\hline T1OS R46E & 8 & $\begin{array}{l}\text { May Petroleur } \\
\text { Inc. } \\
\text { c/o NcIlroy- } \\
\text { Adans Co. } \\
\text { Rm. } 103 \\
152 \mathrm{~N} \text {. Durbin } \\
\text { Casper, WY } \\
82601\end{array}$ & $\begin{array}{c}\text { Federal } \\
\text { it } 1-8\end{array}$ & $\begin{array}{l}9-77 \text { to } \\
9-78\end{array}$ & 16750 & $\begin{array}{l}\text { P\&A; BHC-CH; } \\
\text { DIL/SFI; IRT; } \\
\text { CAL; FDC/CNL; } \\
\text { cyberlook; } \\
\text { geologic rpt; } \\
\text { nud log }\end{array}$ & Caribus & $\begin{array}{l}\text { Plugged and } \\
\text { abandoned. }\end{array}$ \\
\hline
\end{tabular}


T10S R46E

20

May Petroleum Inc.

Elk Valley $\# 1$

$7-76$ to $8-76$ One Energy Sq. 4925 Greenville Dallas, TX 75206

TIOS R46E

\section{Amerada Petro-} leum

Amerada

T1-W1

it 1.

\section{Petroleum}

35

lluday Exploration

420 S. State

Preston, ID

83263

T12S R25E
17
Marsh Basin

$8-63$ to

$10-63$

Bannock

3435

$\dot{t}$

1926 0 il \& Gas

3919

Sonic log-

gamua ray

Laterolog,

micro 1atero-

$\log$, induc-

tion-elect.

Lithologic

log, geolo-

gists rpt.,

temperature

log, hydro-

carbon, mud

$\log$

4115

Gamma ray-

neutron

Cont dip

meter

Sonic log-

gamma xay

Latero $10 \mathrm{~g}$

hydrocarbon

$1926 \quad 3855$

Permit $6-7-73$, not drilled.

600
Yes

Power

Abandoned.

Bannock

Caribou

Caribou

Abandoned.

Yes

Cassia

Abandoned. 


\begin{tabular}{|c|c|c|c|c|c|c|c|c|}
\hline TOWNSHIP & SEC. & COMPANY & WELL NAME & LATE & DEPTH & LOGS & Coun'ry & RENGRKS \\
\hline T12S R37E & 1 & $\begin{array}{l}\text { Nuday Explora- } \\
\text { tion } \\
420 \text { S. State } \\
\text { Preston, ID } \\
83263\end{array}$ & $\begin{array}{l}\text { Bannock } \\
2 \AA 1\end{array}$ & $\dot{x}$ & & & Baunock & $\begin{array}{l}\text { *Permit } 5-7-78 \text {, } \\
\text { not drilled. }\end{array}$ \\
\hline T12S R38E & 8 & $\begin{array}{l}\text { Nuday Explora- } \\
\text { tion } \\
420 \text { S. State } \\
\text { Preston, ID } \\
63263\end{array}$ & $\begin{array}{l}\text { Bannock } \\
1 \mathrm{~A} 8\end{array}$ & $\begin{array}{l}8-78 \text { to } \\
9-78\end{array}$ & 1840 & $\begin{array}{l}\text { DIFI. } \\
\text { BHC Acoustic } \\
\text { Densilog }\end{array}$ & Bannock & \\
\hline T12S R43E & 3 & $\begin{array}{l}\text { Ladd Petroleum } \\
830 \text { Den. Club } \\
\text { Bldg. } \\
\text { Denver, Co } \\
80202\end{array}$ & $\begin{array}{l}\text { Bennington } \\
\text { \# } 3-24\end{array}$ & & $\begin{array}{l}\text { Pro. } \\
13500\end{array}$ & & $\begin{array}{l}\text { Tear } \\
\text { Lake }\end{array}$ & App 7-15-79. \\
\hline TI2S R46E & 30 & $\begin{array}{l}\text { Kocky Mtn. Oil } \\
\text { Co. }\end{array}$ & Government & $\begin{array}{l}8-53 \text { to } \\
12-54\end{array}$ & 5013 & Mydrocarbon & $\begin{array}{l}\text { Beall } \\
\text { Lake }\end{array}$ & $\begin{array}{l}\text { Abandoned, dry } \\
\text { hole. }\end{array}$ \\
\hline T13S R44E & 22 & $\begin{array}{l}\text { Am. Quasar Pet- } \\
\text { roleum } \\
307 \text { United Bank } \\
\text { Tower } \\
1200 \text { Broadway } \\
\text { Denver, Co } \\
30290\end{array}$ & Jensen $22-1$ & $\begin{array}{l}9-77 \text { to } \\
1-78\end{array}$ & 11780 & $\begin{array}{l}\text { BHC Sonic } \\
\text { comp Neutrou } \\
\text { FD dual lat- } \\
\text { erolog, TL } \\
\text { mud log, sur- } \\
\text { vey, l6 DST' } \\
\text { Shale dens }\end{array}$ & $\begin{array}{l}\text { Barr } \\
\text { Lake }\end{array}$ & $\begin{array}{l}\text { Plugged and } \\
\text { abandonet. }\end{array}$ \\
\hline
\end{tabular}




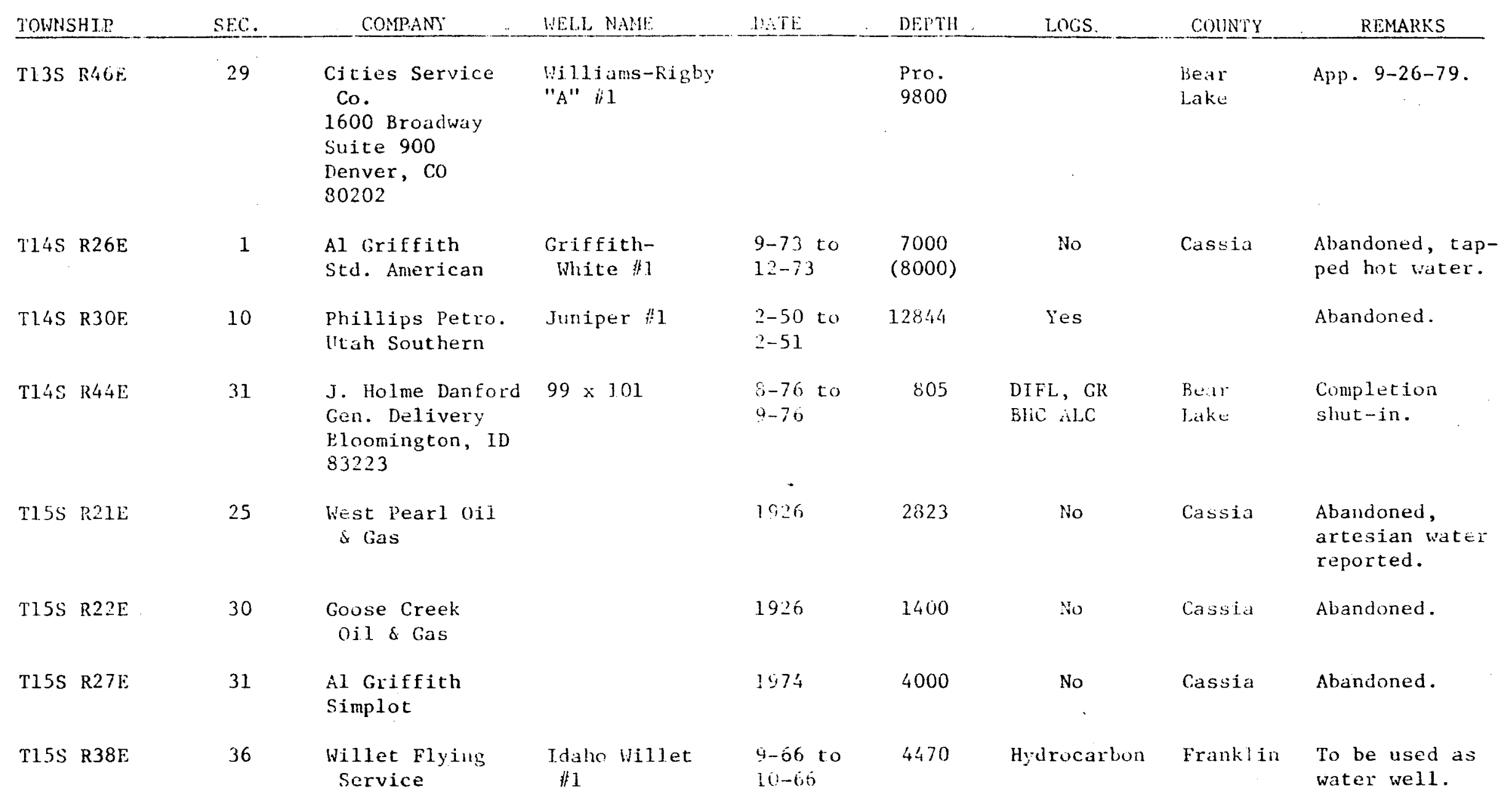




\begin{tabular}{|c|c|c|c|c|c|c|c|c|}
\hline TOWNSHIP & SEC. & CONPANY & HELL NAME & DATE & DFPTH & LOGS & Coung'Y & REMARKS \\
\hline T15S R43E & 1 & $\begin{array}{l}\text { J. Holme Danford } \\
\text { Gen. Delivery } \\
\text { Blonmington, ID } \\
83223\end{array}$ & $99 \therefore 104$ & $\begin{array}{l}2-77 \text { to } \\
6-77\end{array}$ & 809 & Mud $\log r$ & $\begin{array}{l}\text { Bear } \\
\text { Laké }\end{array}$ & $\begin{array}{l}\text { Completion } \\
\text { shut-in. }\end{array}$ \\
\hline T15S R45E & 34 & $\begin{array}{l}\text { Standard of } \\
\text { California }\end{array}$ & $\begin{array}{l}\text { Sheep Creek } \\
\text { \#1 }\end{array}$ & $\begin{array}{l}5-52 \text { to } \\
12-52\end{array}$ & 6768 & Hydrocarbon & $\begin{array}{l}\text { Bear } \\
\text { Lake }\end{array}$ & $\begin{array}{l}\text { Abandoned, dry } \\
\text { hole. }\end{array}$ \\
\hline T16S R24E & 26 & $\begin{array}{l}\text { Cougar Mining } \\
\text { Co. }\end{array}$ & Spencer & 1926 & 500 & Wo & Cassia & Abandoned. \\
\hline T1́S R27E: & 9 & $\begin{array}{l}\text { Al Griffith } \\
\text { Simplot }\end{array}$ & it 1 & $\begin{array}{l}6-74 \text { to } \\
7-74\end{array}$ & 4100 & Yes & Cassia & Abandoned. \\
\hline T16S R28E & 20 & Al Griffith & $\| 1$ & $\begin{array}{l}9-73 \text { to } \\
10-73\end{array}$ & 6981 & Yes & Cassia & rlugged. \\
\hline T16S R38E & 15 & $\begin{array}{l}\text { Utah-Idaho Ex- } \\
\text { ploration Co. }\end{array}$ & $\begin{array}{l}\text { August Jensen } \\
\# 1\end{array}$ & 1956 & 5233 & $\begin{array}{l}\text { Garma Ray- } \\
\text { Neutron } \\
\text { Microlatero- } \\
\text { log } *\end{array}$ & Frankin & $\begin{array}{l}\text { *ávailable fron: } \\
\text { Rocky Mtn. Hell } \\
\text { Log Service, } \\
\text { Denver, Co. }\end{array}$ \\
\hline T16S R46E & 10 & $\begin{array}{l}\text { An. Quasar Petro- } \\
\text { leun } \\
707 \text { linited bank } \\
\text { Tower } \\
1200 \text { Broadway } \\
\text { jenver, Co } \\
80290\end{array}$ & $\begin{array}{l}\text { Grace Feder:l } \\
10-1\end{array}$ & $\begin{array}{l}2-78 \text { 10 } \\
8-78\end{array}$ & 11860 & $\begin{array}{l}\text { PEA; FDC-CNL; } \\
\text { BHC-GR; DLL; } \\
\text { HRT' }\end{array}$ & $\begin{array}{l}\text { Bear } \\
\text { Lake }\end{array}$ & $\begin{array}{l}\text { Plugged and } \\
\text { aiandoned. }\end{array}$ \\
\hline
\end{tabular}


This information comes from the index file of Phosphate Leases in Idaho, as maintained by the Idaho Department of Lands. The information is presented by lessee, gives the lease number, date of issue, location (resolution to one section), the acreage, and county.

Alumet Co.; P.O. Box 630; Golden Co 80401 Total Acres: 600

$\begin{array}{llllll}\text { Lease No. } & \text { Date } & \text { Location } & \text { Section } & \text { Acres } & \text { County } \\ 3914-\mathrm{R} & 10-4-64 & 8 \mathrm{~S} 44 \mathrm{E} & 31 & 160 & \text { Caribou } \\ 5594 & 3-20-74 & 8 \mathrm{~S} 43 \mathrm{E} & 24 & 160 & \text { Caribou } \\ 5596 & 3-20-74 & 8 \mathrm{~S} 44 \mathrm{E} & 30,31 & 280 & \text { Caribou }\end{array}$

Earth Sciences, Inc.; Hwy 93 North;

Golden, CO 80401

Total Acres: 958

\begin{tabular}{|c|c|c|c|c|c|}
\hline Lease No. & Date & Location & Section & Acres & County \\
\hline $4010-R$ & $4-8-66$ & $14 S \quad 43 E$ & 16 & 320 & Bear Lake \\
\hline $4011=R$ & $4-8-66$ & $14 \mathrm{~S} \quad 43 \mathrm{E}$ & 16 & 360 & Bear Irake \\
\hline 5497 & $7-29-73$ & $14 S \quad 43 E$ & 15 & 139 & Bear Lake \\
\hline 7196 & $4-19-76$ & $14 \mathrm{~S} \quad 43 \mathrm{E}$ & 15 & 139 & Bear Lake \\
\hline
\end{tabular}

FMC Corp.; P.O. Box 4111

Pocatello, ID 83201

Total Acres: 480

$\begin{array}{llllll}\text { Lease No. Date } & \text { Location } & \text { Section } & \text { Acres } & \text { County } \\ 3823-\mathrm{R} & 10-30-63 & 8 \mathrm{~S} 44 \mathrm{E} & 16 & 360 & \text { Caribou } \\ 3848 & & 6 \mathrm{~S} 40 \mathrm{E} & 20,21 & 120 & \text { Caribou }\end{array}$

Monsanto Co.; Box 816

Soda Springs, ID 83276

Total Acres: 4815

Lease No.

Date
$j-4-65$
$10-29-65$
$10-29-65$
$10-29-65$
$5-1-78$
$5-1-78$
$5-1-78$

Location

Section

Acres

County

$3941-R$

$3951-R$

$3953-R$

$3954-R$

7955

7956

7957
8S $43 \mathrm{E}$

$6 S \quad 42 E$

6S $39 E$

$7 S \quad 4 O E$

$5 S \quad 38 E$

$8 S \quad 42 E$

$6 S \quad 43 E$
15,22

24,25

16

16

36

36

16
Caribou

Caribou

Caribou

Caribou

Caribou

Caribou

Caribou 
TABLE 10 Continued

Monsanto Co. (Continued)

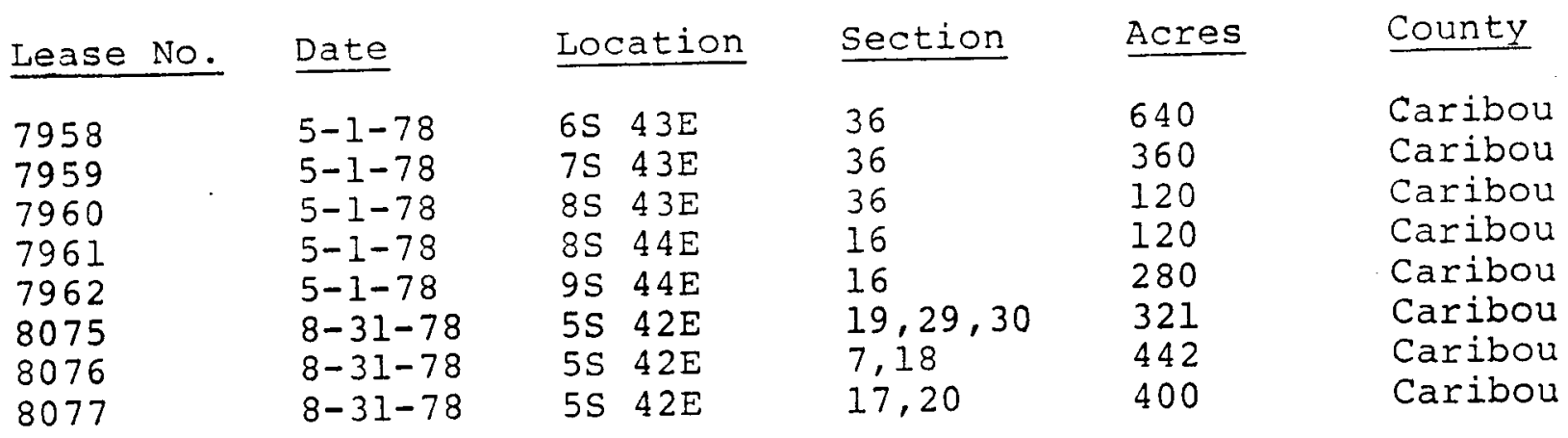

Stauffer Chemical Co.

Star Route; Randolph, UT 84064

Total Acres: 320

\begin{tabular}{|c|c|c|c|c|c|}
\hline Lease No. & Date & Location & Section & Acres & County \\
\hline 3213 & $7-1-78$ & $14 \mathrm{~S} \quad 44 \mathrm{E}$ & 36 & 320 & Bear Lake \\
\hline
\end{tabular}




\section{FEDERAL PHOSPHATE LEASES}

EAST OF R. $20 \mathrm{E}$.

This information comes from the Serial Register pages of Phosphate Leases in Idaho, as maintained by the Bureau of Land Management. Information is presented by lessee, gives the lease number, date issued, the term of the lease, location (Resolution to the section), acreage and county.

ARCHER, ELIZABETH B.

Box 8031, Foothill station

Salt Lake City, UT 84108

Lease No. Date Issued

$1014914 \quad 5-1-70$
Term of

Lease

1 Yr.
Location Acres County

$7 \mathrm{~S} \quad 44 \mathrm{E} \quad 24 \quad 184.95$ Caribou
Term of

Lease

$20 \mathrm{Yr}$.

20 Yr.

20 Yr.

20 Yr.

\section{Location}

$14 \mathrm{~N} \quad 41 \mathrm{E} \quad 7,8,17$

$14 \mathrm{~N} \quad 40 \mathrm{E} 12$

$14 \mathrm{~N} 40 \mathrm{E} 11,12$,

$10011683 \quad 5-3-63$

$10012890 \quad 10-1-62$

$\begin{array}{lllllll}6 & \mathrm{~S} & 43 & \mathrm{E} & 27 & 13,14 & 626.02 \\ 8 & \mathrm{~S} & 45 & \mathrm{E} & 24 & 120 \\ 8 & \mathrm{~S} & 46 & \mathrm{E} & 18,19,20 \\ 29,30,31 & \\ 9 & \mathrm{~S} & 46 & \mathrm{E} & 6,7 & \end{array}$

$9 \mathrm{~S} 46 \mathrm{E} 6,7$

BEKER INDUSTRIES CORP.

124 W. Putnam Ave.,

Greenwich, CT 06830

Lease No. Date Issued

Lease

$1013649 \quad 12-1-66$

1 Yr.

Location

Acres County

$\begin{array}{llllll}9 & \mathrm{~S} & 44 & \mathrm{E} & 8,9 & 120\end{array}$

Caribou 
CONDA PARTNERSHIP

P.O. BOX 68,

Conda, ID 83230

\begin{tabular}{llllllll} 
Lease No. & $\begin{array}{c}\text { Date } \\
\text { Issued }\end{array}$ & $\begin{array}{c}\text { Term of } \\
\text { Lease }\end{array}$ & & Location & Acres & County \\
\hline I 04979 & $4-1-54$ & $20 \mathrm{Yr}$ & $9 \mathrm{~S} 44 \mathrm{E} 2^{2}$ & 321.25 & Caribou \\
I 04979 & $10-1-50$ & $20 \mathrm{Yr}$. & $8 \mathrm{~S} 44 \mathrm{E} 44 \mathrm{E} 3,4,10,14,15,23,24$ & $1,522.24$ & Caribou \\
I 012989 & $11-1-62$ & $20 \mathrm{Yr}$. & $9 \mathrm{~S} 44 \mathrm{E} 14,15,23$ & 560 & Caribou
\end{tabular}

F. P. CHAMP \& WILLIAMS FAMILY PARTNERSHIP

Box 436 ,

Logan, UT 84321

Date Term of

Lease No. Issued Lease

Location

I $013731 \quad 8-1-63 \quad 20 \mathrm{Yr}$

$9 S 44 \mathrm{E} \quad 9,10,11$

Acres County

360 Caribou

EARTH SCIENCES INC, et al

Earth Science Road,

Golden, CO 80401

\begin{tabular}{|c|c|c|c|c|}
\hline Lease & $\begin{array}{l}\text { Date } \\
\text { Issued }\end{array}$ & $\begin{array}{l}\text { Term of } \\
\text { Lease }\end{array}$ & \multicolumn{2}{|c|}{ Location } \\
\hline 101 & $7-1-62$ & $20 \mathrm{Yr}$ & $14 \mathrm{~S} 43 \mathrm{E}$ & 21 \\
\hline $\begin{array}{lll}I & 0 & I\end{array}$ & $5-1-69$ & $1 \mathrm{Yr}$. & $9 \mathrm{~S} 43 \mathrm{E}$ & 15,22 \\
\hline I 0149 & $7-1-69$ & $I$ Yr. & $7 \mathrm{~S} 45 \mathrm{E}$ & 31,32 \\
\hline I 0149 & $7-1-69$ & $1 \mathrm{Yr}$. & 8.S $45 \mathrm{E}$ & 16 \\
\hline $\begin{array}{lll}I & 0 & 152\end{array}$ & $8-1-69$ & $1 \mathrm{Yr}$. & $8 S 46 E$ & 29,32 \\
\hline$\left[\begin{array}{ll}0 & 16\end{array}\right]$ & $5-1-69$ & $1 \mathrm{Yr}$. & $9 \mathrm{~S} 43 \mathrm{E}$ & 22 \\
\hline
\end{tabular}

Acres County

65.74 Bear Lake

400 Caribou

360 Caribou

360 Caribou

280 Caribou

$40 \quad$ Caribou

FMC CORP. et al

Box 4111,

Pocatello, ID 83201 Term of

Lease No. Issued Lease

Iocation

Acres County

I 203(a) 12-I-71 1 Yr. T 5 S, R 37E 3,4,10

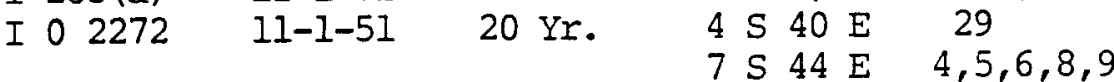

I $05975 \quad 6-1-55 \quad 20 \mathrm{Yr} . \quad 6 \mathrm{~S} 44 \mathrm{E} \quad 32$

8 S $45 \mathrm{E} \quad 21,22,28,33$

I $08194 \quad 5-1-57 \quad 20$ Yr. $\quad 9$ S 45 E $4,9,16$

I 011775 8-1-65 $20 \mathrm{Yr}$. 7 S 43 E $22,23,26,27$

I $011866 \quad 2-1-67 \quad 1$ Yr. $\quad 8$ S 44 \# 32,35

3 S 40 E 29,32

I 011877 12-1-66 $1 \mathrm{Yr}$. 4 S $40 \mathrm{E} 5$

$440 \quad$ Bannock

80 Bingham

I 013215 12-1-66 1 Yr. 6 S 41 E 19

620.88 Caribou

1636.98 Caribou

$560 \quad$ Caribou

396.74 Caribou

835.47 Bingham 481.12 Caribou

Continued - next page 
FMC CORP. et al

Box 4111,

Pocatello, ID 83201

Continued

\begin{tabular}{|c|c|c|c|c|c|c|}
\hline Lease No. & $\begin{array}{l}\text { Date } \\
\text { Issued }\end{array}$ & $\begin{array}{c}\text { Term of } \\
\text { Lease }\end{array}$ & \multicolumn{2}{|c|}{ Iocation } & Acres & County \\
\hline I 013729 & $6-1-67$ & 1 Yr. & $7 \mathrm{~S} 43 \mathrm{E}$ & 26 & 120 & Caribou \\
\hline I 014184 & $4-1-68$ & $1 \mathrm{Yr}$. & $8 \mathrm{~S} 44 \mathrm{E}$ & 8,9 & 320 & Caribou \\
\hline I $0 \quad 14664$ & $4-1-68$ & $1 \mathrm{Yr}$. & $6 \mathrm{~S} 40 \mathrm{E}$ & $6,7,8,17,18,21$ & 1159.34 & Caribou \\
\hline I 015033 & $9-1-68$ & I Yr. & $6 \mathrm{~S} 43 \mathrm{E}$ & 17 & 160 & Caribou \\
\hline I 015035 & $3-1-69$ & $1 Y r$ & 7 S $43 \#$ & 18 & 200 & Caribou \\
\hline I 015041 & $7-1-69$ & $1 \mathrm{Yr}$. & $5 \mathrm{~S} 43 \mathrm{E}$ & $29,30,32,33$ & 507.08 & Caribou \\
\hline I 015097 & $9-1-64$ & $20 \mathrm{Yr}$. & $8 \mathrm{~S} 44 \mathrm{E}$ & $5,6,8$ & 719.38 & Caribou \\
\hline I 015122 & $9-1-64$ & $20 \mathrm{Yr}$. & $6 \mathrm{~S} 43 \mathrm{E}$ & $21,22,27$ & 360 & Caribou \\
\hline I 015821 & $9-1-65$ & $20 \mathrm{Yr}$. & $9 \mathrm{~S} 44 \mathrm{E}$ & 6 & 120.43 & Caribou \\
\hline I 015940 & $11-1-69$ & $1 \mathrm{Yr}$. & $4 \mathrm{~S} 41 \mathrm{E}$ & $20,21,22,27,28$ & 520 & Bingham \\
\hline
\end{tabular}

LEONARD J. JARRAND

53 E. 4th S.

Salt Lake City, UT 84111

- Date Term of

Lease No. Issued Lease

$\begin{array}{lllllll}\text { I } 0 & 16876 & 7-1-69 & \text { Yr. } & 14 \mathrm{~N} & 41 \mathrm{E} & 19\end{array}$

$14 \mathrm{~N} 40 \mathrm{E} \quad 13,14,24$

Acres County

845.7 Clark

INTERNATIONAL MINERALS \& CHEMICAL CORP.

5401 Old Orchard Road

Skokie, ILL

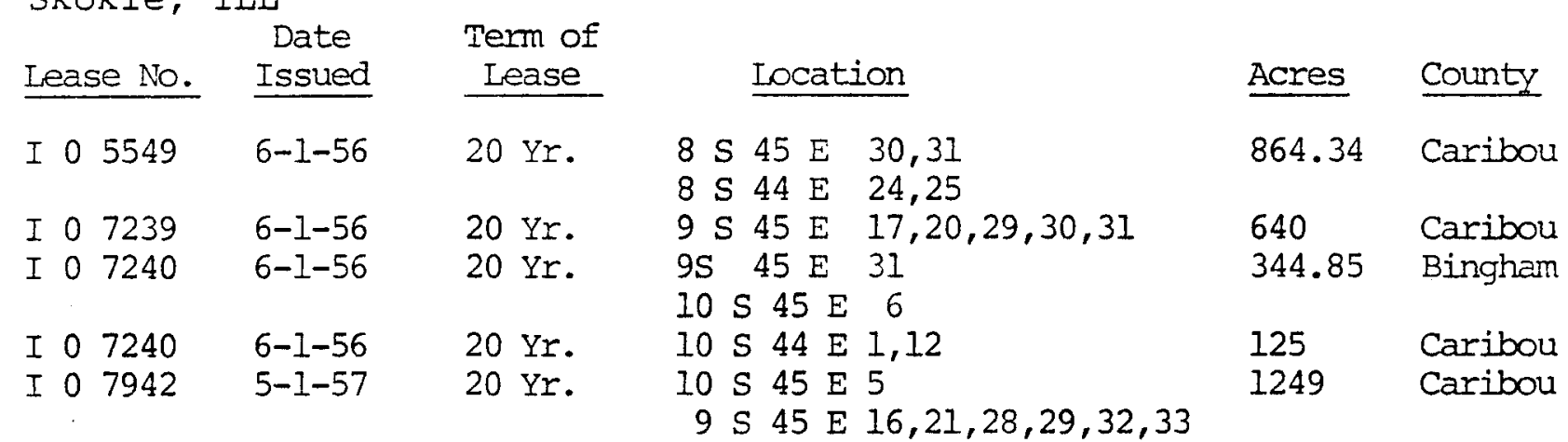


MONSANTO CO.

Box 816,

Soda Springs, ID 83276

* - Phosphate use permit

\begin{tabular}{|c|c|c|c|c|c|c|c|}
\hline \multirow{2}{*}{$\frac{\text { Lease }}{\text { BL } O}$} & No. & $\begin{array}{l}\text { Date } \\
\text { Issued }\end{array}$ & $\begin{array}{l}\text { Term of } \\
\text { Lease }\end{array}$ & \multicolumn{2}{|c|}{ Iccation } & \multirow{2}{*}{$\frac{\text { Acres }}{280.95}$} & \multirow{2}{*}{$\begin{array}{l}\text { County } \\
\text { Caribou }\end{array}$} \\
\hline & 55375 & $12-1-48$ & 20 Yr. & $\mathrm{T}$ TS R 43 & E Sec. 7 & & \\
\hline $\mathrm{BLO}$ & 55894 & $12-1-48$ & $20 \mathrm{Yr}$ & T 95 R 44 & E Sec. 9 & 200 & Caribou \\
\hline BLO & 56009 & $12-1-48$ & $20 \mathrm{Yr}$ & $\mathrm{T}$ QS $\mathrm{R} 44$ & E Sec. 15 & 200 & Caribou \\
\hline $\mathrm{BL} O$ & 56192 & $9-1-49$ & $20 \mathrm{Yr}$ & T $65 \mathrm{R} 38$ & E Sec. 1 & 65.34 & Caribou \\
\hline I 144 & $13 *$ & $3-1-79$ & $1 \mathrm{Yr}$. & $6 S 43 E$ & 31 & 40 & Caribou \\
\hline I 0 & 1 & $9-1-49$ & $20 \mathrm{Yr}$ & $9 \mathrm{~S} 43 \mathrm{E}$ & 10,11 & 200 & Caribou \\
\hline I 0 & 2 & $9-1-49$ & $20 \mathrm{Yr}$. & $8 \mathrm{~S} 43 \mathrm{E}$ & 12 & 120 & Caribou \\
\hline I 0 & 3 & $9-1-49$ & $20 \mathrm{Yr}$. & $9 \mathrm{~S} 43 \mathrm{E}$ & 2 & 160.65 & Caribou \\
\hline $\begin{array}{lll}I & 0 & 1\end{array}$ & 6 & $9-1-49$ & $20 \mathrm{Yr}$ & $4 S 40 E$ & 29 & 160 & Bingham \\
\hline I 02 & 57 & $11-1-49$ & $20 \mathrm{Yr}$. & $9 \mathrm{~S} 43 \mathrm{E}$ & 7 & 120 & Caribou \\
\hline I 02 & 58 & $11-1-49$ & $20 \mathrm{Yr}$. & $9 \mathrm{~S} 44 \mathrm{E}$ & 18 & 80 & Caribou \\
\hline I 06 & 78 & $12-1-51$ & $20 \mathrm{Yr}$. & $\begin{array}{llll}8 & S & 44 & E \\
5 & S & 40 & E\end{array}$ & $\begin{array}{l}15,22 \\
2\end{array}$ & 200 & Caribou \\
\hline $\begin{array}{lll}I & 0 & 9 \\
I & 0 & 9\end{array}$ & $\begin{array}{l}97 \\
97\end{array}$ & $10-1-50$ & 20 Yr. & $4 \mathrm{~S} 40 \mathrm{E}$ & $28,33,34,35$ & $\begin{array}{l}591 \\
80.25\end{array}$ & $\begin{array}{l}\text { Bingham } \\
\text { Caribou }\end{array}$ \\
\hline$I 01$ & 1005 & $10-1-50$ & $20 \mathrm{Yr}$ & $\begin{array}{llll}6 & S & 39 & E \\
5 & S & 39 & E\end{array}$ & $\begin{array}{l}6 \\
31\end{array}$ & 200 & Caribou \\
\hline$I 01$ & 440 & $10-1-50$ & $20 \mathrm{Yr}$. & $10 \mathrm{~S} 45 \mathrm{E}$ & $9,16,21,28$ & 1080 & Caribou \\
\hline I 01 & -441 & $10-1-50$ & $20 Y r$. & $10 \mathrm{~S} 45 \mathrm{E}$ & $3,4,9$ & 438.29 & Caribou \\
\hline I 05 & 613 & $6-1-55$ & $20 \mathrm{Yr}$ & $\begin{array}{llll}7 & S & 42 & E \\
7 & S & 43 & E\end{array}$ & $\begin{array}{l}22,23,26,35 \\
6,7,18\end{array}$ & 520 & Caribou \\
\hline I 05 & 7723 & $6-1-55$ & $20 \mathrm{Yr}$ & $7 \mathrm{~S} 42 \mathrm{E}$ & 12,13 & 668.91 & Caribou \\
\hline I 05 & 860 & $6-1-55$ & $20 \mathrm{Yr}$. & $5 \mathrm{~S} 41 \mathrm{E}$ & 19,20 & 120 & Caribou \\
\hline I 01 & .1451 & $9-1-60$ & $20 \mathrm{Yr}$. & $\begin{array}{llll}6 & S & 42 & E \\
6 & S & 43 & E\end{array}$ & $\begin{array}{l}10,11,13,14,24 \\
10,29,30,31,32\end{array}$ & 1402.85 & Bonneville \\
\hline $\begin{array}{lll}I & 0 & 1\end{array}$ & 3709 & $12-1-65$ & $20 \mathrm{Yr}$. & $7 \mathrm{~S} 42 \mathrm{E}$ & 26,35 & 80 & Caribou \\
\hline $\begin{array}{lll}I & 0 & 1\end{array}$ & 3719 & $3-1-69$ & $1 \mathrm{Yr}$. & $8 \mathrm{~S} 43 \mathrm{E}$ & 26,27 & 520 & Caribou \\
\hline $\begin{array}{lll}I & 0 & 1\end{array}$ & 3720 & $10-1-68$ & $1 \mathrm{Yr}$. & $8 \mathrm{~S} 43 \mathrm{E}$ & 14 & 200 & Caribou \\
\hline I 0 & 13778 & $11-1-66$ & $1 \mathrm{Yr}$. & $8 \mathrm{~S} 44 \mathrm{E}$ & 19 & 212.28 & Caribou \\
\hline $\begin{array}{lll}I & 0 & 1\end{array}$ & 3814 & $12-1-65$ & $20 \mathrm{Yr}$. & $6 \mathrm{~S} 43 \mathrm{E}$ & 31,32 & 80 & Caribou \\
\hline $\begin{array}{lll}I & 0 & 1\end{array}$ & 4080 & $4-1-64$ & $20 \mathrm{Yr}$. & $\begin{array}{llll}8 & S & 43 & E \\
8 & S & 44 & E\end{array}$ & $\begin{array}{l}12,13,24 \\
7,18,19\end{array}$ & 697.08 & Caribou \\
\hline
\end{tabular}

EA REX MINING CORP.

Box 430,

Las Vegas, NV

Date Term of

Iease No. Issued Lease

Iocation

Acres County

I $06433 \quad 8-1-59 \quad 20$ Yr. $\quad 2$ N $42 \mathrm{E} \quad 25,35,36$

$1 \mathrm{~N} 42 \mathrm{E} \quad 1,12$

$1 \mathrm{~N} 43 \mathrm{E} 6,7$

I $06638 \quad 8-1-59 \quad 20 \mathrm{Yr}$. IN $43 \mathrm{E} \quad 21,22,25,26,27,35,36$

$1 \mathrm{~N} 43 \mathrm{E} \quad 35,36 \quad 1520$

1604.9 Bonneville

I N $44 \mathrm{E} 31$

I $010763 \quad 8-1-59 \quad 20 \mathrm{Yr}$. I S $44 \mathrm{E} \quad 5,6,8,9$

1416.84 Bonneville

I $010764 \quad 8-1-59 \quad 20 \mathrm{Yr}$. IN $43 \mathrm{E} 7,8,16,17,18,20,211363.95$ Bonneville 
J. R. SIMPLOT CO.

Box 27,

Boise, ID 83707

Date Term of

Lease No. Issued

Lease

Location

$\begin{array}{lllllllll}B L & 0 & 55163 & 2-1-49 & 20 \mathrm{Yr} . & \text { I S } & 39 \mathrm{E} & 31\end{array}$

I 203 (a) 12-1-71

I $01603 \quad 3-1-52$

$1 \mathrm{Yr}$.

$5 \mathrm{~S} \quad 37 \mathrm{E} \quad 3,4,10$

$20 \mathrm{Yr}$.

$9 \mathrm{~S} \quad 43 \mathrm{E} \quad 8,15,16,17,21,22$

7 S 42 E 35

8 S 43 E 19

I $044949-1-54 \quad 20 \mathrm{Yr}$.

8 S 42 E $2,11,14,15,24$

6 S $39 \mathrm{E} \quad 1,2,12$

I 09945

6-1-59 $20 \mathrm{Yr}$.

5 S $39 \mathrm{E} \quad 21,27,28,34,35$

I 010338

6-1-59

$20 \mathrm{Yr}$.

$1 \mathrm{Yr}$.

$20 \mathrm{Yr}$

$20 \mathrm{Yr}$.

$\begin{array}{lll}I & 0 & 13708 \\ I & 0 & 15523\end{array}$

$8-1-65$

5 S 40 E $10,29,30$

8 S 42 E 2,11

8 S 42 E 23

I $015820 \quad 8-1-65$

$9 \mathrm{~S} 43 \mathrm{E} 2,3$

J. R. SIMPLOT CO.

$\mathrm{PH}$ Use permit

Box 67,

Conda, ID 83238

Lease No. $\begin{gathered}\text { Date } \\ \text { Issued } \\ \text { I } 4298\end{gathered}$
STAUFFER CHEMICAL CO.
Star Route

Randolph, UT 84064

to Use Permit

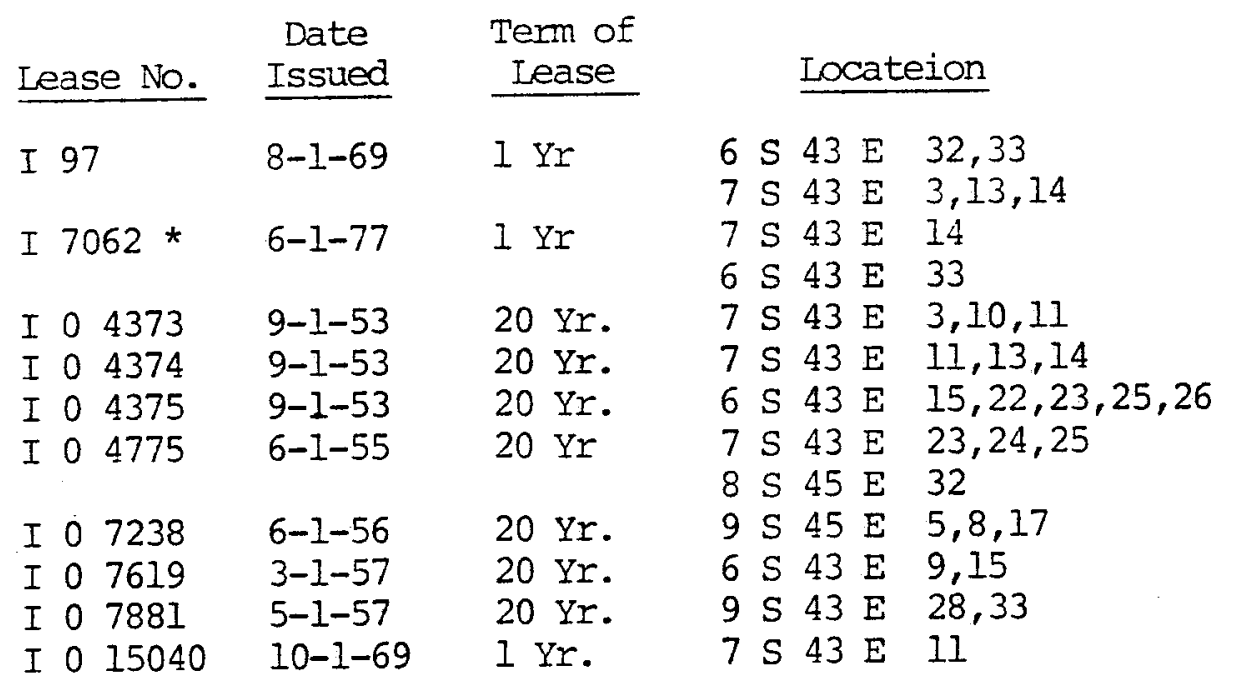

Acres County

307.99 Caribou

60

Caribou

467.73 Caribou

520 Caribou

800 Caribou

440 Caribou

518.12 Caribou

360 Caribou

360 Caribou

120 Caribou

* Phosphate Use Permit 


\section{REFERENCES}

Dames \& Moore Co., Natural Gas Supply Reguirements for the State of Idaho, Report to the Idaho Public Utilities Commission, 1977.

Dewey, J.W., W.L. Dillinger, J. Taggart, and S.W. Algermissen, A Technique For Seismic Zoning: Analysis of Earthquake Locations and Mechanisms in Northern Utah, Myoming, Idaho, and Montana, Proc. Intern. and Microzonation, 2nd, Seattle, WA, 1972 .

Drysdale, F.R. and C.E. Calef, The Energetics of the United States of America: An Atlas, Brookhaven National Laboratory, 1977.

EG \& G Idaho, Inc., Rules of Thumb for Geothermal Direct Applications, September, 1978 .

Idaho Department of water Resources, Population and Employment Forecast, State of Icaho, 1978.

Idaho Division of Budget, Policy Planning and Coordination, County Profiles of Idaho, State of Idaho, 1978.

Index File, State Geothermal Leases, Idaho Department of Lands, Bureau of Minerais, Division of Earth Resources, 1979.

Index File, State Oil and Gas Leases, Idaho Department of Iands, Bureau of Minerals, Division of Earth Resources, 1979.

Index File, State Phosphate Leases, Idaho Department of Iands, Bureau of Minerals, Division of Earth Resources, 1979.

Lienau, P.J., Agribusiness Geothermal Energy Utilization Potential of Klamath and Western Snake River Basins, Oregon. Geo-Heat Utilization Center, Oregon Institute of Technology, 1978.

Makey, D.R. and C.M. Tschanz, Aeromagnetic Survey Map of Idaho, U.S. Geological Survey, $197 \overline{8 .}$

Mitchell, J.C., Geochemistry and Geological Setting of the Thermal waters of the Northern Cache Valley Area, Franklin County, Idaho, Water Information Bull. 30, Part 5, Geothermal Investigations in Idaho, Idaho Department of Water Resources, 1976.

Mitchell, J.C., L.L. Johnson, and J.E. Anderson, Potential for Direct Heat Applications of Geothermal Resources, Water Information Bull. 30, Part 9, Geothermal Investigations in Idaho, Idaho Department of Water Resources, 1979.

Muffler, L.P., Edt., Assessment of Geothermal Resources of the United States - 1978, U.S. Geological Survey Circular 790, 1979. 
Pennington, W.D., R.B. Smith and A.B. Trinkle, A Microearthquake Survey of Parts of the Snake River Plain and Central Idaho, Bull. of the Seismological Society of America, Vol. 64, No. 2 pp. 307-312, April, 19:4.

Ross, Sylvia Geothermal Potential of Idaho, Idaho Bureau of Mines and Geology, Pamphlet 150, Moscow, Idaño, No.v. 1971.

Serial Register Pages, Federal Geothermal Leasing, U.S. Department of the Interior, Bureau of Land Management, 19.79.

Serial Register Pages, Federal Oil and Gas Leasing, U.S. Department of Interior, Bureau of Land Management, 1979.

Serial Register Pages, Federal Phosphate Leasing, U.S. Department of Interior, Bureau of Land Management, 1979.

Sisco, H.G. Ground Water Levels and Descriptions of Observation Wells in Idaho, 1975, Idaho Department of Water Resources Bulletin 43, Boise, Idaho, Dec. 1976.

Smith, R.B. and M. Sbar, Intraplate Tectonics and Seismicity of the western United States, cited in Pennington, et al, Bull, of the Seismological Society of America, Vol. 64, No. 2, April, 1974.

Tschanz, C.M., T.H. Killsgaard, and D.A. Seeland, Mineral Resources of the Eastern Part of the Sawtooth National Recreation Area, Custer and Blaine Counties, Idaho, U.S. Geological Survey Open File Report, 1974 .

University of Idaho, Manufacturing Directory of Idaho, Center for Business Development and Research, 1979.

U.S. Geological Survey, Final Environmental Impact Statement, Development of Phosphate Resources in Southeastern Idaho, U.S. Department of Interior, Geological Survey, Bureau of Land Management and U.S. Department of Agriculture, Forest Service, 1976.

Van Ornum, J.V. and G. Simmons, Industrial Waste Heat For Adjacent Communities and Industrial Applications, Task II Report, Volume IV, Idaho Date Base, Rocket Research Company, Redmond, Washington, and the Pacific Northwest Regional Commission, 1978.

Vincent, K.R. and J.K. Applegate, A Preliminary Evaluation of the Seismicity of Southwestern Idaho and Eastern Oregon: Implications for Geological Engineering Studies, Department of Geology and Geophysics, Boise State University, Boise, Idaho, 1978.

Young, H.W. and J.C. Mitchel1, Geochemistry and Geological Setting of Selected Thermal Waters, Geothermal Investigations in Idaho, Water Info. Bul1. 30, Part I, Idaho Department of Water Resources, 1973. 